\title{
JOSIANE PICCOLO
}

\section{A criança dependente de ventilador: concepções e práticas de cuidado frente a suas necessidades de desenvolvimento}

Dissertação apresentada à Escola de Enfermagem da Universidade de São Paulo no Programa de PósGraduação em Enfermagem para obtenção do titulo de mestre em enfermagem.

Área de concentração: Enfermagem Pediátrica

Orientadora: Maria De La Ó Ramallo Veríssimo

SÃO PAULO

2008 
Meus filhinhos, o nosso amor não deve ser somente de palavras e de conversa. Deve ser um amor verdadeiro, que se mostra por meio de ações.

$1^{a}$ João 3:18 


\section{AgradeCi MEntos}

Primeiramente, agradeço a Deus, pelo privilégio de testemunhar de sua graça ao longo dos dias tão incertos e, também, por ter me dado a chance de retomar e desenvolver esta pesquisa. Obrigada, por ter abençoado dias difíceis com momentos inesquecíveis e pessoas especiais.

A meus filhos, Júlia, Vinícius e Luiza, que insistentemente moldam meu mundo, reeducando minha forma adulta de viver. Como é bom aprender com vocês!

A meu querido esposo Adams, com quem compartilho meus sonhos, pelo seu amor tão diário, incentivo e admiração. Eu, realmente, sou feliz por tê-lo!

A Débora, minha amiga querida, pela sua lealdade e disposição em ajudar. Você não tem preço!

A meus pais, por terem me ensinado tantos valores sobre a vida.

A minha querida mãe, exemplo de fé, amor e dedicação, que não cansou de orar por mim e para que este trabalho fosse finalizado.

Às admiráveis mulheres que estiveram onde não pude estar; assumiram responsabilidades que não pude assumir e cuidaram tão bem daqueles que eu amo, em especial, a Inês, vó coruja. Obrigada, pelos ensinamentos.

À Professora Dra. Maria De La Ó Ramallo Veríssimo, minha orientadora, por ter acreditado em meu potencial e me ajudado no desenvolvimento e conclusão deste trabalho, dividindo conhecimentos e experiência.

À Professora Cecília Helena de Siqueira Sigaud, que sempre me ouviu e aconselhou, obrigada por zelar por mim! 
Às Professoras Magda Andrade Rezende, Elaine Buchhorn Cintra Damião e Lisabelle Rossato, pelo incentivo dado, pela sabedoria compartilhada e exemplo. Tenho o privilégio de tê-las como amigas!

Aos funcionários e docentes do Departamento de Enfermagem Materno Infantil e Psiquiátrica, pela convivência, carinho e respeito.

Finalmente, a todos que diretamente ou indiretamente contribuíram para que este trabalho fosse concluído. 
Piccolo J. A criança dependente de ventilador: concepções e práticas de cuidado frente suas necessidades de desenvolvimento. [dissertação]. São Paulo: Escola de Enfermagem, Universidade de São Paulo; 2008.

\section{Resumo}

Este estudo objetivou identificar na literatura de saúde textos que abordassem aspectos do desenvolvimento de crianças dependentes de ventilador; caracterizar ações de cuidado realizadas ou propostas para a promoção do desenvolvimento dessas crianças, assim como, analisá-las, segundo o referencial de necessidades essenciais da infância proposto por Brazelton e Greenspan (2002). O processo de busca bibliográfica realizado nas bases de dados PubMed, Lilacs, Embase e Cinahl e a leitura dos resumos, possibilitaram a organização dos artigos localizados em 17 grupos temáticos, sendo eleitos para a análise temática de conteúdo somente os que potencialmente continham informações relacionadas às perguntas da pesquisa. $\mathrm{O}$ corpus da análise constituiu-se de 35 artigos internacionais que pertenciam aos seguintes grupos temáticos: (1) processo de transição do hospital para casa/comunidade, (2) experiência da criança e da família, (3) interação criança-cuidador, (4) qualidade de vida, (5) proteção e segurança e (6) artigos de revisão. Os critérios para seleção dos documentos e análise pautaram-se no modelo metodológico de análise de Bardin (1977). A análise temática possibilitou a construção de duas categorias sobre o ambiente de cuidados e o desenvolvimento de crianças dependentes de ventilador. A categoria Concepções e práticas que resultam em cuidado desigual agrupou as diferentes concepções sobre infância e dependência de tecnologia ventilatória, e, como conseqüência, os contextos de assistência diversos, ou mesmo, opostos aos quais as crianças em ventilação prolongada foram submetidas. Revelou as ações, pensamentos, experiências e situações que dão existência ao contexto desfavorável ao atendimento das necessidades integrais da criança ou do adolescente dependente de ventilador, assim como aquelas que proporcionam condições mais favoráveis ao desenvolvimento. Sinalizou tanto as oportunidades como os desafios que estavam presentes em todos os cenários de atenção à saúde da criança e estabeleciam-se nas interações entre criança, ambiente e cuidador, resultando em maior ou menor desenvolvimento do potencial de cada criança. A categoria Potenciais de desenvolvimento efetivados versus potenciais de desenvolvimento comprometidos forneceu evidências sobre a competência da criança dependente de ventilador nas tarefas esperadas do desenvolvimento, tais como a socialização e o aprendizado, favorecidas no contexto de cuidados integrais. Ainda, descreveu distúrbios físicos, comportamentais e de desenvolvimento, potencialmente associados a contextos desfavoráveis, marcando os 
prejuízos a que seu potencial foi submetido. Notaram-se, nos artigos analisados, a preocupação e o empenho dos pais, profissionais e instituições para melhorar o contexto de atenção às necessidades de saúde das crianças dependentes de ventilador. No entanto, destacaram-se as ações que privilegiam a necessidade de proteção física e segurança em detrimento das demais necessidades essenciais para o desenvolvimento.

Descritores: Respiração artificial. Desenvolvimento infantil. Crianças Portadoras de Deficiência. Determinação de Necessidades de Cuidados de Saúde.

Palavras-chave: Criança dependente de ventilador. Criança dependente de tecnologia. Ventilação domiciliar. 
Piccolo J. The ventilator-dependent child: concepts and care practices concerning his/her developmental needs. [thesis]. São Paulo (SP), Brasil: Escola de Enfermagem, Universidade de São Paulo; 2008.

\section{Abstract}

This study aimed to identify in health literature papers that dealt with developmental aspects of ventilator-dependent children, to characterize care actions proposed or given so as to promote these children's development, and at the same time to analyze such actions according to the Irreducible Needs of Children framework proposed by Brazelton and Greenspan (2002). Search for bibliography in PubMed, Lilacs, Embase and Cinahl and abstract reading made it possible to organize articles in 17 theme groups. However, theme analysis was carried out using only the articles that potentially contained information related to the research questions. Analysis corpus is made up of 35 articles from foreign sources belonging to the following group themes: (1) transition process from hospital to home/community, (2) child's and family's experience, (3) child-care giver interaction, (4) life quality, (5) protection and safely and (6) review articles. Criteria to select documents and analysis followed Bardin's (1977) methodological model analysis. Theme analysis enabled the construction of two categories about care settings and ventilator-dependent children. The category Concepts and practices resulting in unequal care encompassed different concepts about childhood and ventilation technology dependence and thus the different or even opposite settings concerning care to which prolonged ventilator-dependent children are submitted. This concept also revealed actions, thoughts, experiences and situations that bring about both the unfavorable setting of providing for the comprehensive needs of ventilator-dependent child or adolescent and those that provide more favorable conditions for their development. It also pointed to opportunities and challenges present in all settings pertaining to the child's health care that are established in the interactions between child, environment and caregiver, resulting in higher or lower level of development of each child's full potential. The category Effective developmental potentials vs. Compromised developmental potentials provided evidences about competences of the ventilatordependent child to perform developmental tasks, such as socializing and learning, which a comprehensive care setting favors. It also described physical, behavioral and developmental disorders potentially associated with unfavorable settings which compromise the child's and adolescent's full potential. The analyzed studies showed that parents, health care professionals and institutions are concerned and making efforts to improve the health care setting of ventilator-dependent children. However, actions 
aimed at providing physical protection needs and safety are more favored to the detriment of other essential needs for their full development.

Descriptors: Artificial respiration. Children's development. Disabled children. Establishing health care needs.

Keywords: Ventilator-dependent children. Technology dependent children. Home care ventilation. 


\section{LISTA DE QUADROS}

QUADRO 1 - GRUPOS TEMÁTICOS IDENTIFICADOS COM BASE NA LEITURA DOS RESUMOS DOS ARTIGOS ENCONTRADOS.

QUADRO 2 - DISTRIBUIÇÃO DAS PUBLICAÇÕES IDENTIFICADAS, LOCALIZADAS

E EXCLUÍDAS APÓS AVALIAÇÃO. 


\section{STA DE TABELAS}

TABELA 1 - DISTRIBUIÇÃO DOS ARTIGOS ANALISADOS SEGUNDO A FONTE DE

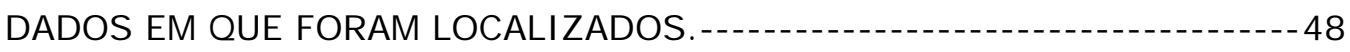

TABELA 2 - DISTRIBUIÇÃO DOS ARTIGOS ANALISADOS, SEGUNDO OS ANOS DE PUBLICAÇÃO.

TABELA 3 - DISTRIBUIÇÃO DOS ARTIGOS ANALISADOS, DE ACORDO COM O PERIÓDICO DE PUBLICAÇÃO. -

TABELA 4 - DISTRIBUIÇÃO DOS ARTIGOS ANALISADOS SEGUNDO A ÁREA PROFISSIONAL DE SEUS AUTORES.

TABELA 5 - DISTRIBUIÇÃO DOS ARTIGOS ANALISADOS SEGUNDO O LOCAL DE REALIZAÇÃO DO ESTUDO. 


\section{SUMÁRIO}

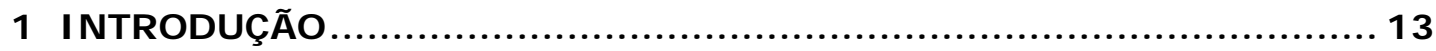

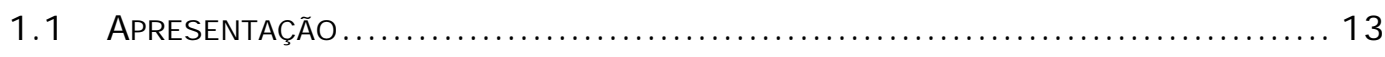

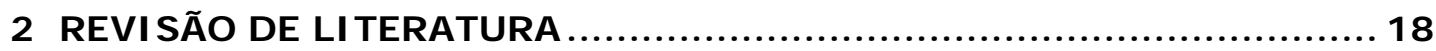

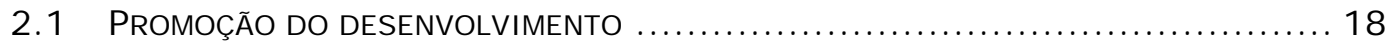

2.2 A CRIANÇA COM DEMANDA DE TECNOLOGIA PARA SUPORTE DA VIDA $\ldots \ldots \ldots \ldots \ldots . \ldots 26$

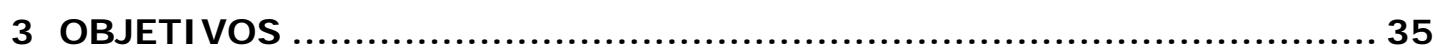

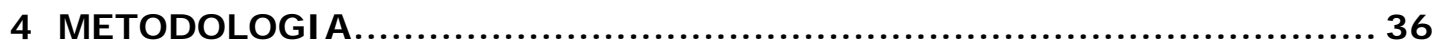

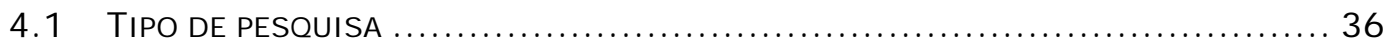

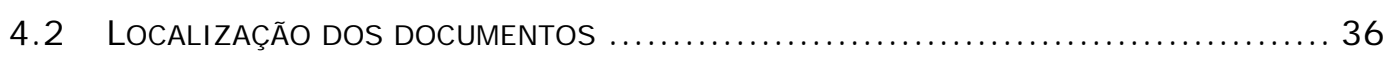

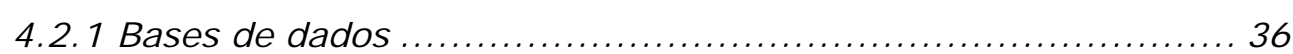

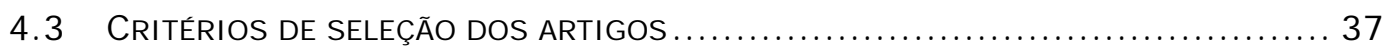

4.4 DEFINIÇÃO DOS DESCRITORES............................................. 38

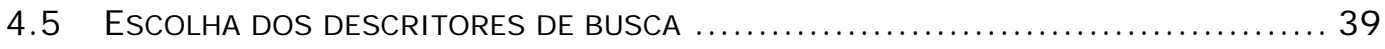

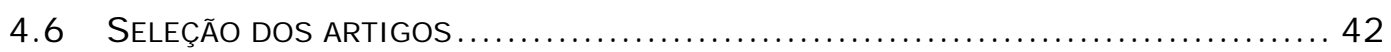

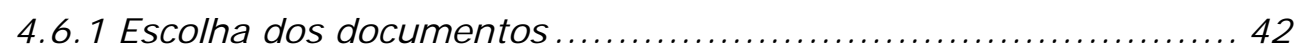

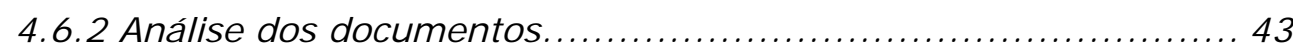

4.6.3 Pré-análise - Escolha dos documentos a serem analisados ....... 43

4.6.4 Elaboração dos indicadores - Seleção dos recortes .............. 45

4.6 .5 Exploração do material ..................................... 46

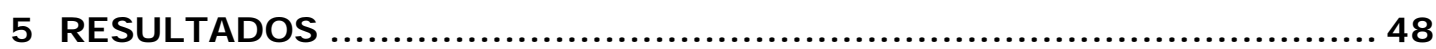

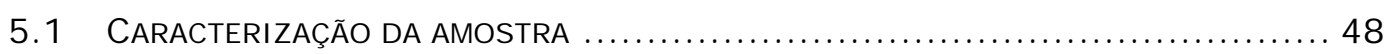

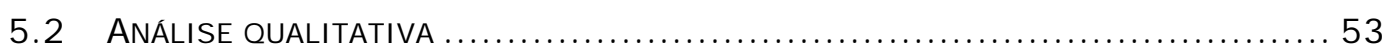

5.2.1 Concepções e práticas que resultam em cuidado desigual ........ 53

5.2.1.1 Contexto desfavorável ao desenvolvimento global da criança dependente de ventilador............................................ 55

5.2.1.1.1 Concepções "negativas" sobre depender de ventilação artificial na infância ..................................................... 55

5.2.1.1.2 Experiências difíceis vividas pela criança.................63 63

5.2.1.1.3 Estrutura e suporte social inadequados...................71

5.2.1.2 Contexto favorável ao desenvolvimento global da criança dependente de ventilador.

5.2.1.2.1 Concepções "positivas" sobre depender de ventilador artificial na infância 
5.2.1.2.2 Oportunidades que ajudam as crianças dependentes de ventilador perceberem seus potenciais

5.2.1.2.3 Ações de promoção à saúde integral da criança dependente de tecnologia.....

5.2.2 Potenciais de desenvolvimento efetivados versus potenciais de desenvolvimento comprometidos.

5.2.2.1 Potencial efetivado: competência da criança dependente de ventilador para desenvolver-se, conforme esperado

5.2.2.1.1 A criança é competente para comunicar-se .99

5.2.2.1.2 A criança é competente para desenvolver confiança no cuidador e estabelecer relacionamentos seguros

5.2.2.1.3 A criança é competente para socialização. 102

5.2.2.1.4 A criança é competente para aprender 103

5.2.2.2 Potencial comprometido: danos ao desenvolvimento/ à vida da criança dependente de ventilador

5.2.2.2.1 Sentimentos de desvalor, exclusão e isolamento..... 104

5.2.2.2.2 Prejuízos à formação de vínculo entre pais e criança. 105

5.2.2.2.3 Distúrbios físicos, comportamentais e de desenvolvimento. 105

5.2.2.2.4 Morte. 107

6 DISCUSSÃO. 108 


\section{Introdução}

\subsection{Apresentação}

No decorrer de minha trajetória profissional, encontrei muitas oportunidades para refletir sobre o papel do enfermeiro que tem a criança como alvo de cuidado. Ainda nas aulas do curso de graduação, aprendi a respeito das diversas formas de atuar do enfermeiro com a criança e sua família e gostaria de destacar aquela que se embasa nos pressupostos do cuidado centrado na pessoa.

No âmbito de saúde da criança, o enfermeiro que desenvolve seu papel empregando como referencial o cuidado centrado na pessoa, utiliza conhecimentos, habilidades e pensamentos à disposição da pessoa, da criança e de sua família (Ângelo, Veríssimo, 1996). Entende que a criança é um ser único, em processo de desenvolvimento, capaz de utilizar recursos internos e externos para expressar sentimentos e necessidades, assim como para satisfazê-los. Ao encontrar condições facilitadoras, a criança cresce e desenvolve seu potencial humano, precisando ser respeitada e atendida em suas necessidades (Sigaud, Veríssimo, 1996).

Na perspectiva da abordagem centrada na pessoa, a atuação do enfermeiro contempla ações de defesa da criança e da família, bem como de promoção e restauração da saúde da criança (Ângelo, Veríssimo, 1996).

Em razão de minha afinidade com tais premissas, ao iniciar minhas atividades profissionais na Unidade de Cuidados Intensivos Pediátricos - UCIP-, busquei apoio nesta perspectiva.

O cenário dos cuidados intensivos foi assustador pelos inúmeros procedimentos especializados e a situação de dor e sofrimento imposta às crianças e famílias. Vivi muitas experiências, algumas boas e outras nem tanto, mas a vivência singular de um menino despertou-me para uma 
realidade até então desconhecida. Esse menino, vítima de trauma medular ocorrido no momento do parto, estava hospitalizado naquele ambiente, por longos sete anos e dependia de ventilação mecânica para viver.

Sensibilizei-me com aquela condição, pois acredito que "morar na Unidade de Terapia Intensiva (UTI)" seja uma situação difícil e com potencial de causar dano a qualquer criança.

Ao longo dos anos de trabalho naquela Unidade, cuidei não só de crianças criticamente doentes, mas também de um número cada vez maior de menores com condições crônicas de saúde e necessidades especiais de cuidados. Crianças que sobreviviam às suas limitações de saúde pelo uso contínuo de recursos tecnológicos e cuidados especializados, a maioria tinha vencido a prematuridade ou sofria de doenças degenerativas.

$\mathrm{Na}$ Unidade de Cuidados Intensivos Pediátricos, percebi que as famílias tomavam conhecimento de que seus filhos precisariam de cuidados especiais e recursos tecnológicos para se manterem vivos por longo período ou até por toda a vida. Assim, após a estabilidade do quadro clínico inicial, o destino de cada criança estava diretamente ligado aos recursos materiais que cada família possuía.

Sempre que a tecnologia fosse compatível com a realidade social de suas famílias, a criança voltava para casa, não antes de seus familiares serem treinados para executar cuidados relacionados à tecnologia. Famílias asseguradas ou as que possuíam convênio médico-hospitalar podiam contar com o apoio de profissionais vinculados a um serviço especializado de cuidados domiciliares, para cuidar de seus filhos em casa.

No entanto, o suporte especializado não impedia que as crianças retornassem ao hospital ou para submeterem-se a intervenções decorrentes do processo de crescimento, como por exemplo, a substituição da cânula de traqueostomia atual para uma de maior diâmetro, ou na vigência de complicações. 
Por outro lado, os filhos de famílias não asseguradas permaneciam na unidade de terapia intensiva pediátrica, mesmo sem necessitar de cuidados intensivos ou eram encaminhados para casa sem o suporte técnico necessário, já que não existia recurso público para atender tais crianças.

Dentro desse contexto, a situação das crianças dependentes de ventilador foi a que mais me despertou interesse, pois não podiam ir para casa sob o cuidado exclusivo de seus pais. Em um período de cinco anos de atuação nesse local, observei que seu cotidiano ficava atrelado à rotina de trabalho da unidade e havia poucas estratégias instituídas para cuidar delas integralmente.

Atividades que estimulassem a interação social e autonomia dependiam de ações isoladas dos integrantes da equipe. Períodos de lazer e recreação estavam vinculados, na maioria das vezes, à disponibilidade de equipamentos e de pessoal. Assim, os momentos de distração fora da unidade eram escassos, rápidos e em condições inadequadas. Somente uma criança possuía ventilador portátil, as demais recebiam ajuda ventilatória por meio de bolsa de pressão positiva durante os passeios internos.

Ainda que a perda da capacidade ventilatória pudesse estar associada a comprometimento das áreas do desenvolvimento, o prejuízo para essas crianças parecia ser ainda maior, considerando a escassez de possibilidades e experiências oferecidas.

A idéia de que o ambiente domiciliar e a convivência diária com familiares e com a comunidade oferecessem melhores oportunidades para seu desenvolvimento psicossocial, levou-me a conversar com pais e cuidadores a respeito do dia - a - dia das crianças assistidas por home care. Percebi que, embora oportunidades de desenvolvimento e socialização pudessem ser oferecidas, ainda assim o ambiente domiciliar assemelhavase ao hospitalar. 
As respostas que me pareciam mais prováveis para justificar esta reprodução do ambiente hospitalar no domicílio eram duas. Primeiro, o atendimento das necessidades da criança dependente de ventilador está diretamente vinculado à importância que o profissional de saúde atribui à questão e o quanto ele sabe sobre as demandas decorrentes do processo de desenvolvimento e como conciliá-las com a situação especial da própria criança. Em segundo lugar, a complexa situação vivenciada pelos pais e familiares acarretava alteração na vida da família, exigia a aquisição de novos conhecimentos sobre a doença e o desenvolvimento de habilidades técnicas para cuidar da criança, podendo modificar a forma dos pais verem seus filhos.

Ainda na UTI, famílias de crianças com traqueostomia ou gastrostomia, com condições clínicas e sociais para cuidado no domicílio, recebiam treinamento sobre os cuidados com a tecnologia, o que em parte é responsabilidade do enfermeiro e que assumi com grande entusiasmo.

Desse modo, procurei aperfeiçoar o treinamento dos pais de crianças com traqueostomia, mediante o desenvolvimento de um manual de orientações de cuidados para a criança. Esse manual, produto de minhas inquietações, apresenta a proposta preconizada pela American Society Thoracic (Sherman et al., 2000), como também aquelas relacionadas à promoção do desenvolvimento, por exemplo, os cuidados com a criança durante o sono, banho e alimentação; a importância da reabilitação da fala e do brincar. Durante a fase de treinamento e preparo dos cuidadores, compartilhávamos dúvidas sobre o cotidiano da criança, assim como aquelas referentes aos cuidados com a traqueostomia (Piccolo et al., 2002).

Após cinco anos trabalhando na Unidade de Cuidados Intensivos Pediátricos, iniciei minhas atividades profissionais com o corpo docente da Pediatria da Escola de Enfermagem da Universidade de São Paulo (EEUSP), em 2004. 
Assim, meu trabalho na Universidade contempla atividades de apoio à docência e leva-me a desenvolver ações com alunos de graduação, acompanhando-os em diversas situações de aprendizado, inclusive, no campo de prática. No hospital, um dos campos de prática dos alunos de graduação, deparei-me novamente com a realidade das crianças dependentes de ventilador. Constatei que o cotidiano delas na unidade de internação pediátrica em muito se assemelhava àquele do ambiente de terapia intensiva.

Nesse mesmo período, inseri-me no grupo de pesquisa "Cuidado e promoção da saúde e do desenvolvimento infantis"• da EEUSP. As atividades do grupo contemplam a investigação, o ensino e a extensão universitária dirigidos à melhoria do desenvolvimento e saúde da criança em diversos cenários de atendimento. No grupo de pesquisa, minha participação ratificou meu interesse para estudar mais detidamente as necessidades de desenvolvimento das crianças dependentes de ventilador.

O presente estudo surgiu da confluência dessas inquietações: de um lado, a dura realidade das crianças dependentes de ventilador; de outro, a escassez de publicações e pesquisas nacionais sobre o tema. Desta forma, este trabalho buscou integrar a proposta de ampliação do olhar para a criança com necessidades especiais e procurou desenvolver conhecimentos que sirvam de subsídios aos profissionais que atuam com essas crianças.

- Grupo de pesquisa cadastrado no CNPq. Informações disponíveis em: http://www.ee.usp.br/departamento/cuidado saude infantil.htm?grupo=0067404JCDMVY2 


\section{Revisão de literatura}

\subsection{Promoção do desenvolvimento}

Em decorrência do desenvolvimento humano, mudanças físicas, sociais, cognitivas, psíquicas e morais ocorrem ao longo da vida. O indivíduo inicia essa trajetória em um estado de absoluta dependência, ainda no período gestacional, por meio de interações complexas e progressivas entre o amadurecimento e a aprendizagem, ou seja, entre o indivíduo e o meio social, desenvolve-se em suas singularidades. Entende-se por meio social, o ambiente e as relações estabelecidas entre o indivíduo e as demais pessoas de convívio. Inicialmente, a criança estabelece uma relação significativa com seu cuidador primário, geralmente, a mãe. Após os relacionamentos expandem-se aos demais cuidadores, família e comunidade (Sigaud, Veríssimo, 1996).

A Organização Pan-Americana da Saúde (OPAS) ressalta que:

\footnotetext{
O desenvolvimento é um processo de humanização: um processo pelo qual nos convertemos em pessoas dignas e inteligentes, através da aquisição de símbolos e de formas de comunicação que expressam nossas idéias e sentimentos e, também, da aquisição de valores e normas de convivência. Sem o estímulo exterior, sem as interações sociais, a humanização não se produz, a inteligência não se constrói. (OPAS, 2000, p. viii)
}

O desenvolvimento infantil, período que compreende os estágios iniciais do desenvolvimento humano, é representado por modificações quantitativas e qualitativas no funcionamento da criança, que só são possíveis por meio da inter-relação dos fenômenos crescimento, maturação e aprendizagem. Subentende-se por crescimento, primordialmente, o desenvolvimento físico, como por exemplo, o aumento da massa muscular e a estabilização do esqueleto. Já a maturação, é entendida como a realização 
de um determinado nível de capacidade funcional que torna possível efetivar um comportamento como a aquisição do equilíbrio para andar. Geralmente, a aprendizagem é considerada no sentido de modificação do comportamento, ou seja, oferecer a oportunidade para a criança realizar a ação (Hockenberry, Winkelstein, 2006).

Muitos teoristas debruçaram-se sobre o desenvolvimento infantil. Cada um deles lançou seu olhar sobre os aspectos específicos que thes pareciam mais importantes ou interessantes. Desta forma, o estudo do desenvolvimento infantil é fragmentado e classificado por faixas etárias e áreas de interesses. Por exemplo, Freud e Erikson realizaram pesquisas para compreender um dos aspectos do desenvolvimento infantil, a personalidade, mas cada um enfatiza uma abordagem diferente para esta área por meio da leitura dos aspectos psicossexuais e psicossociais, respectivamente. Já Piaget deteve-se no desenvolvimento mental (Hockenberry, Winkelstein, 2006).

A classificação em faixas etárias é conveniente para "descrever as características associadas à maioria das crianças nas épocas em que alterações distintas no desenvolvimento aparecem e tarefas específicas do desenvolvimento devem ser realizadas" (Wong, 1999a, p. 74), mas por desconsiderar as diferenças individuais não pode ser aplicada a todas as crianças com um grau de precisão adequado. Assim, Hockenberry e Winkelstein (2006) adotam a seguinte seqüência para descrever os períodos e subperíodos do desenvolvimento infantil: da concepção ao nascimento, do nascimento aos 12 meses (lactente), de um a seis anos de idade (infante e pré-escolar), dos seis aos 12 anos (escolar) e, o fim da infância, período entre 11 e 19 anos (adolescente).

As mesmas autoras dividem o desenvolvimento infantil em áreas de desenvolvimento, a saber: físico, que se relaciona à maturação esquelética, neurológica, dos sistemas orgânicos e motor; da personalidade, que compreende o desenvolvimento psicossexual e psicossocial; o mental, 
que diz respeito ao desenvolvimento cognitivo, da linguagem, moral e espiritual; do autoconceito que aborda a imagem corporal e a auto-estima.

Da análise dos vários estudiosos, emerge que o desenvolvimento infantil está intimamente ligado às questões como interação com o meio, seu ambiente de cuidado e as oportunidades e estímulos à aprendizagem. O ambiente de cuidado inclui as formas de cuidado e as condições físicas do ambiente; deve ser capaz de prover as necessidades essenciais da infância, compreendidas como aquelas quando atendidas possibilitam 0 desenvolvimento emocional, intelectual e social da criança (Grupo de Pesquisa "Cuidado à saúde infantil", 2008).

No intuito de responder quais são os tipos de cuidados que toda criança precisa para se desenvolver, Brazelton e Greenspan (2002) definiram sete necessidades mínimas e essenciais. As necessidades essenciais da infância, de acordo com estes autores, são as experiências e cuidados que toda criança têm direito, por fornecerem o substrato para o desenvolvimento das capacidades emocionais, sociais e intelectuais. Segue uma breve apresentação de cada necessidade identificada pelos autores.

- Necessidade de relacionamentos sustentadores consistentes e contínuos: traduz-se na experiência entre criança e adulto (pais e cuidadores secundários) capaz de fornecer cuidado sensível. Provê estabilidade emocional, estímulo para aprendizagem, segurança física, além de proteção e abrigo.

- Necessidade de proteção física, segurança e regulamentação: refere-se a um conjunto de cuidados relacionados à "prevenção dos insultos fisiológicos e melhorar os ambientes familiar e físico nos quais a criança cresce".

- Necessidade de experiências que respeitem as diferenças individuais: diz respeito aos cuidados que garantem o caráter único de cada criança. Aumenta a possibilidade da criança 
crescer adequadamente, assim como normaliza as expectativas da família e da sociedade em relação à criança.

- Necessidade de experiências adequadas ao desenvolvimento: que são as voltadas a cada fase do desenvolvimento, compreende a ação cuidadosa de acrescer novas interações às anteriores em um contínuo evolutivo que acompanha a necessidade individual de cada criança.

- Necessidade do estabelecimento de limites, organização e expectativas: limites estabelecidos de maneira adequada, 0 incentivo e o reconhecimento de suas realizações e feitos promovem disciplina e ajudam a criança a estabelecer seus próprios objetivos; por meio de cuidados afetuosos, a confiança, a intimidade, a empatia e o vínculo desenvolvem-se na criança.

- Necessidade de comunidades estáveis, amparadoras e Necessidade de continuidade cultural: aqui duas necessidades diferentes juntam-se para explicar a importância da comunidade e da cultura que estruturam o contexto para o atendimento das demais necessidades e fornecem a apoio para famílias e, conseqüentemente, para que a criança se desenvolva.

Percebe-se que Brazelton e Greenspan (2002), quando definem as necessidades essenciais da infância, caminham dentro da perspectiva psicossocial de desenvolvimento, reforçando a importância da interação da pessoa com seu ambiente.

Hoje, sabe-se que a interação afetiva é muito importante para a satisfação das necessidades biológicas da criança, inclusive para garantir sua sobrevivência (Shore, 2000). 
Veríssimo e Andrade destacam a importância das ações de cuidado, como por exemplo, a proteção contra acidentes e o acompanhamento do crescimento e desenvolvimento para o atendimento das necessidades de sobrevivência e desenvolvimento de crianças pequenas. As autoras entendem que o cuidado é o alicerce do processo de desenvolvimento e, que a "atitude de cuidado", ou seja, a disponibilidade interna de uma pessoa, somada aos conhecimentos, habilidades e valores que esta possui, pode resultar em ações "direcionadas a manter ou melhorar a condição humana no processo de viver e de morrer" (Veríssimo, Rezende, 2004, p. 72).

As atividades diárias como brincar, vestir, alimentar, banhar são ricas em oportunidades para criar vínculo e propiciar o desenvolvimento da criança. O banho, por exemplo, é um excelente momento de contato e toque. Da interação criança/cuidador, podem surgir possibilidades para suprir algumas necessidades, como a de relacionamentos sustentadores, que são estimulados pelo toque, brincadeiras e demonstrações de afeto, com estabelecimento de vínculo. As necessidades de segurança física, também, estão contidas nele, uma vez que é preciso garantir que a temperatura da água esteja adequada e não ocorram acidentes durante o banho. Aqui também é possível oferecer oportunidades e experiências adequadas a cada fase do desenvolvimento, por meio de brincadeiras, de estímulo da autonomia e autocuidado, à medida que a criança cresce. As regras e limites, também, fazem parte da hora do banho, quando este acaba e torna-se uma rotina de cuidados.

O suporte que o cuidador recebe, pode influenciar no modo como as oportunidades de desenvolvimento da criança são vivenciadas, por exemplo, as oportunidades possíveis no momento do banho podem ser ou não aproveitadas. Uma pesquisa comparou o comportamento de mães e bebês durante o banho e constatou que mães com maior rede de suporte social emitiam com mais freqüência comportamentos positivos (carinho, manejo delicado, oferecer brinquedos, olhar a criança) que as mães que 
não dividiam a tarefa com outras pessoas. Isto demonstra que as mães com suporte, ou seja, fazem parte de uma comunidade "amparadora", são mais sensíveis às necessidades da criança e têm melhor condição de atender às suas demandas (Silva, Le Pendu, Pontes, 2002). Este estudo ratifica uma das necessidades descritas por Brazelton e Greenspan (2002), a necessidade de comunidades estáveis e amparadoras.

Reconhecer cada criança como um indivíduo único, com características e peculiaridades, é mais uma das necessidades descritas por Brazelton e Greenspan (2002) e isto é fundamental quando o cuidado se orienta pelos princípios da atenção integral, visando aos direitos infantis do desenvolvimento pleno. Cada criança deve ser entendida como uma criatura singular e deve ter seu desenvolvimento estimulado por ações e cuidados que respeitem esta singularidade. Assim, os cuidados voltados ao atendimento das necessidades infantis assumem diferentes configurações ao longo da infância, em razão das variações das especificidades e características de crescimento e desenvolvimento observáveis no período. Além das características individuais das crianças, o cuidado infantil também é moldado pelas condições de vida a que elas estão submetidas, dadas por seu grupo familiar e sua inserção social.

Para que o desenvolvimento da criança siga rumos satisfatórios, é fundamental garantir oportunidades para o atendimento de suas variadas necessidades e que estas sejam apropriadas às peculiaridades da criança em cada etapa de seu desenvolvimento, em geral, o atendimento das necessidades essenciais se faz de forma a integrar mais de uma delas em ações, muitas vezes, simples e cotidianas.

Vale ressaltar que estas perspectivas representam a visão de profissionais de saúde engajados com o cuidado promotor do desenvolvimento humano e que pode diferir da perspectiva das próprias crianças. Desse modo, o relatório da Situação Mundial da Infância (UNICEF, 
2001a) dá voz a crianças do mundo todo. Nele, elas expressam suas opiniões e necessidades e declaram o direito de serem ouvidas.

De acordo com o Fundo das Nações Unidas para a Infância (UNICEF):

O desenvolvimento infantil é um conceito que toma como princípio o fato de a criança ser protagonista de seu próprio desenvolvimento. Ou seja, desde a gestação, o bebê não é propriedade de alguém. A criança é uma pessoa, sujeito de direitos, capaz de modificar os ambientes e as reações das pessoas em volta dela e que, portanto, precisa ser "ouvida" em suas mais diferentes manifestações. (UNICEF, 2001b, p. 9)

A definição demonstra a competência da criança para manifestar suas necessidades, assim como reflete sua vulnerabilidade em relação ao adulto.

O adulto vive sua relação com a criança de um modo complexo e mutável. $\mathrm{Na}$ interação, a resposta do adulto depende da representação que ele tem da criança, e esta é influenciada por experiências prévias, pela cultura e época e por condições de vida e trabalho (Siebert, 1998).

Nas últimas décadas, a infância despertou interesse internacional em razão da redução da mortalidade desse grupo e das pesquisas realizadas sobre o impacto dos primeiros anos de vida na capacidade produtiva dos indivíduos. Este interesse culminou no compromisso de vários Governos e Agências com a proteção da infância e promoção do desenvolvimento integral da criança (OPAS, 2000).

No Brasil, as políticas de saúde seguem as diretrizes estabelecidas na "Agenda de Compromissos para a Saúde Integral da Criança e Redução da Mortalidade Infantil" que enfocam o processo de reorganização da rede de assistência para que contemple a assistência em seus vários níveis de atenção (Brasil, 2005). 
O eixo principal da Agenda de Compromissos é a promoção do crescimento e desenvolvimento infantil. Segundo o UNICEF, promoção do desenvolvimento infantil é:

Um conjunto de ações para a proteção e os cuidados para as crianças em seus primeiros seis anos de vida. Envolve a garantia do convívio familiar e comunitário de meninas e meninos, intervenções nas áreas de saúde, educação e assistência social. O objetivo dessas ações é garantir um bom começo de vida para cada criança. (UNICEF, 2001b, p. 9)

A definição é condizente com o princípio de integralidade do Sistema Único de Saúde (SUS) que propõe a atenção à saúde, como um direito universal ao atendimento das necessidades de saúde.

Mattos (2006) discute o caráter polissêmico do princípio da integralidade que pode ser entendida como a "boa prática" profissional, assim como princípios para a organização do trabalho e de políticas desenhadas para dar respostas a um determinado problema de saúde. Qualquer que seja o sentido adotado, a integralidade implica recusa no reducionismo do sujeito e na busca por respostas para as necessidades apresentadas.

O cuidar técnico e biológico tem sido priorizado por grande parte dos profissionais de saúde em detrimento de cuidados que atendam às necessidades de desenvolvimento de crianças doentes, e isto é ainda mais significante quando se trata de crianças especiais ou aquelas que vivem situações de internação prolongada, ou ainda, as que dependam de tecnologia para viver. É premente reconhecer que cuidar do desenvolvimento das crianças também é uma forma de cuidar de sua saúde, e isto precisa ser compreendido por profissionais de saúde que as atendem. 


\subsection{A criança com demanda de tecnologia para suporte da vida}

Só no decorrer do século $X X$, foi possível sobreviver a uma condição de saúde potencialmente fatal, graças ao avanço nas pesquisas científicas, as quais contribuíram para o desenvolvimento de tecnologias médicas e equipamentos, como o ventilador em 1929 (US Congress, 1987).

Como exemplo, pode-se tomar a epidemia de poliomielite ocorrida na primeira metade do século XX. As vítimas sobreviveram em função da terapêutica ventilatória existente - o pulmão de aço. Em conseqüência, centros de reabilitação respiratória foram criados para atender à demanda de cuidados da população emergente: pessoas dependentes de tecnologia (Tanaka, Imperial, 1993).

Nas últimas décadas, observou-se um aumento na incidência de crianças que necessitam de equipamentos e tecnologia médica, assim como de cuidados complexos de enfermagem para mantê-las vivas (US Congress, 1987). A esta mudança, relaciona-se a redução da mortalidade no período neonatal, sobretudo de recém-nascido com peso inferior a 1.500 gramas, muitos dos quais requererem tecnologias respiratórias, nutricionais e medicamentosas por vários anos ou até mesmo durante toda infância (Wong, 1999b).

Crianças com condições de saúde anteriormente consideradas sem prognóstico recebem tratamentos de ponta, que incorporam o uso de novas tecnologias. Este é o caso daquelas com distrofias musculares, doenças oncológicas ou fibrose cística, dentre outras.

Apesar da estreita relação entre criança e tecnologia, pais e profissionais vivenciam o sucesso de manter estas crianças vivas. No entanto, o custo elevado dos cuidados transformou-se em um problema significativo para o sistema de saúde, mesmo para os países desenvolvidos (US Congress, 1987). 
A definição de "Criança dependente de tecnologia" é recente, data de 1987, e foi elaborada para facilitar a análise de custos que o cuidado com estas crianças representava. O comitê do Senado americano solicitou a seu órgão de pesquisa chamado Office Technology Assessment (OTA), a preparação de um memorando técnico sobre o assunto. Embora não fosse parte do objetivo, o processo contribuiu para uma definição de criança dependente de tecnologia, já que para a realização da investigação foi preciso a caracterização de tal criança (US Congress, 1987). Segundo a definição do estudo:

\footnotetext{
Criança dependente de tecnologia inclui o grupo de crianças que depende de dispositivo médico para compensar a perda de alguma função vital e que necessita de substancial e contínuo suporte de enfermagem a fim de evitar morte ou piora na condição. (US Congress, 1987, p.3)
}

Estas duas características, necessitar de cuidados e de tecnologia, delimitam esse grupo e servem para diferenciá-lo do grupo de crianças que só requerem cuidados adicionais, como por exemplo, as com comprometimento cognitivo ou as que precisam apenas do equipamento tecnológico, como quem usa aparelho auditivo (Glendinning et al., 2001). Cabe ressaltar que algumas crianças dependentes de tecnologia podem dividir características em comum com os grupos acima citados.

A definição de criança dependente de tecnologia desenvolvida pela OTA tem uma forte conotação relacionada ao custo financeiro do cuidado (custo de pessoal capacitado, mais custo associado aos equipamentos e suprimentos), haja vista que este era o foco do estudo. Como esta definição aplicava-se a uma ampla faixa de condições, a OTA subdividiu o grupo de crianças em função de suas características clínicas:

"Grupo I: crianças dependentes de respiradores mecânicos pelo menos em parte do dia". 
"Grupo II: crianças que necessitam de administração prolongada de substâncias intravenosas ou drogas".

"Grupo III: crianças com dependência diária de equipamento respiratório ou nutricional, incluindo traqueostomia, oxigênio".

"Grupo IV: Crianças com dependência prolongada de outros equipamentos médicos que compensem as funções vitais, cuidados de enfermagem diários ou quase diários. Este grupo é representado por:

- Lactentes que requerem monitor de apnéia;

- Crianças que requerem diálise renal em conseqüência de falência renal crônica; e

- Crianças que requerem outros dispositivos médicos, como cateteres urinários, bolsas de colostomia e similares."

Ressalta-se que as crianças pertencentes a um mesmo subgrupo apresentam variações de causa, idade de início da dependência, duração, gravidade e freqüência do uso de tecnologia (Glendinning et al, 2001).

Partindo da definição estabelecida pelo OTA, o The Paediatric Long-term Assisted Ventilation Group, grupo de pesquisadores europeus estudiosos de questões relacionadas à dependência de ventilador, apresenta a seguinte definição para "Criança dependente de ventilador", ou seja, aquelas que necessitam de respiradores mecânicos, pelo menos em parte do dia:

Qualquer criança, quando medicamente estável, requerendo ajuda mecânica para respirar após um reconhecido fracasso no desmame, ou ainda em desmame lento, três meses após o início da ventilação. (Noyes, 1999, p. 440) 
As principais causas da dependência ventilatória são as doenças neurológicas e as pulmonares crônicas. Correspondem à primeira: as neuropatias, as distrofias musculares, a doença de Werdnig-Hoffman, as mielomeningoceles, as encefalopatias pós-anoxia, as quadraplegias, as paraplegias, a paralisia do nervo frênico e a hipoventilação de origem central. Dentre as doenças pulmonares, estão: a displasia broncopulmonar, a traqueomalácia, a laringomalácia e as doenças pulmonares restritivas por escoliose (Gílio, Terra, 1993). Em decorrência do tipo de patologia, as crianças podem apresentar limitações físicas e/ou mentais, o que reforça a necessidade de reabilitação (Spósito, 1993).

As crianças dependentes de ventilador são um grupo relativamente pequeno, com potencial futuro de incremento na incidência e prevalência. Em 1987, о OTA estimou que o número de crianças norteamericanas, entre 0 e 22 anos, dependentes de ventilador, variava entre 680 e 2000 (US Congress, 1987). Dois estudos recentes apontam uma elevação no número de crianças dependentes de ventilador. Um deles, realizado no Estado de Minnesota, compara o número de crianças atendidas em serviços especializados entre os anos 1986, 1992 e 1997, identificando uma elevação de 42\% (Adams, Shapiro, Marini, 1998). O segundo estudo, realizado no Estado de Utah, compara a prevalência destas crianças por meio da análise dos registros do hospital local e ratifica esta informação à medida que demonstra uma elevação de 33 crianças, em 1996, para 44 em 2004 (Gowans, Keenan, Bratton, 2007).

Essas crianças podem viver e serem atendidas em hospitais, clínicas especializadas ou em suas casas, com suporte ou não de equipe profissional. Um estudo realizado no Reino Unido, por meio de questionários dirigidos a clínicas pediátricas, hospitais, serviços especializados e médicos, identificou 141 crianças dependentes entre zero e 16 anos e conseguiu obter informações detalhadas de 136. Verificou que 66 (47\%) crianças recebiam ventilação mecânica invasiva por meio traqueostomia, 62 (44\%) mantinham ventilação mecânica não invasiva com uso de máscara facial, 9 (6\%) 
utilizavam pressão negativa. A maior parte das crianças, 93, vivia no domicílio e 43 permaneciam no hospital. Os motivos que as mantinham, eram: dificuldade organizacional do domicílio, dificuldade em recrutar equipe de enfermagem ou cuidadores treinados e dificuldade de financiamento para o cuidado (Jardine, O'Toole, Paton, Wallis, 1999). No Brasil, não existem estatísticas oficiais e pesquisas que revelem o número de crianças dependentes de ventilador e onde estão - em casa ou no hospital.

A experiência da pesquisadora por atuar na área, e os poucos dados disponíveis mostram que uma parte das crianças que depende de ventilação mecânica invasiva, está sob os cuidados de Serviços de Atenção Domiciliar Privados. Segundo a Resolução Anvisa - RDC no 11, de 26 de janeiro de 2006, esse atendimento é caracterizado pela atenção em tempo integral da Equipe Multiprofissional de Atenção Domiciliar e enquadra-se na Modalidade de Internação Domiciliar (Brasil, 2006a). Surge como possibilidade apenas para crianças com seguro ou convênio privado de saúde. A outra parte das crianças permanece em internação hospitalar, já que no Brasil os programas públicos de internação domiciliar são raros (Lima et al., 2006).

Já as crianças dependentes de ventilação mecânica não-invasiva são assistidas por seus pais ou familiares sob a orientação de profissionais de saúde e têm equipamentos e suprimentos fornecidos pelo Estado, conforme a Portaria no 1.531 de 4 de setembro de 2001 (Brasil, 2001).

$\mathrm{Na}$ tentativa de conhecer o número de crianças brasileiras em ventilação invasiva, efetuou-se uma busca nas fontes oficiais de informação que apresentou as seguintes dificuldades:

- as empresas de Serviço de Assistência Domiciliária estavam em período de carência para registro no Cadastro Nacional de Estabelecimento de Saúde (CNES) - 
Resolução Anvisa - RDC no 11, de 26 de janeiro de 2006. Anexo-item 4.3 (Brasil, 2006a)

- embora o CNES possua uma relação do total de ventiladores por Estado e entidade de saúde (exceto Home-Care), não é possível identificar o uso por idade e condição clínica (Brasil, 2006b)

A "Agenda de compromissos para a saúde integral da criança e redução da mortalidade infantil" propõe diretrizes para o cuidado da criança visando a seu crescimento e desenvolvimento pleno. O capítulo que aborda a criança com necessidades especiais, afirma que:

A criança com necessidades especiais deve receber atenção integral e multiprofissional, possibilitando a detecção dos problemas em tempo oportuno para o desenvolvimento de ações, de diagnóstico e intervenção precoce, de habilitação e reabilitação, promoção de saúde e prevenção de impedimento físico, mental ou sensorial e de agravos secundários, minimizando as conseqüências da deficiência. (Brasil, 2005, p.33)

Recente pesquisa nacional, com objetivo de conhecer a realidade de vida das famílias que cuidavam de seus filhos dependentes de tecnologia em casa, revela que a falta de estrutura básica e os serviços da rede de saúde para atender à demanda de cuidados necessários a estas crianças impõem riscos à saúde e resultam em reinternação (Cunha, Cabral, 2001).

A literatura internacional aponta para uma tentativa de manter essas crianças fora do ambiente hospitalar, sendo que a preocupação com o custo do cuidado, com a qualidade de vida das crianças e de suas famílias tem direcionado essa mudança (Capen, Dedlow, 1998). Entretanto, este tipo de cuidado pode não ser implementado em decorrência de fatores, como a instabilidade clínica da criança, a falta de capacitação dos pais para cuidar da criança em ventilação domiciliar, o suporte financeiro e profissional 
possível a cada família e a rede de apoio disponível na comunidade (Wong, 1999b).

Desse modo, a proposta do cuidado domiciliar é normalizar a vida da criança, minimizar o impacto da doença sobre ela e sua família e promover seu desenvolvimento. $\mathrm{O}$ ambiente domiciliar pode otimizar as oportunidades que as crianças têm de experimentar situações apropriadas a seu desenvolvimento, desde que a equipe multiprofissional e a família estejam aptas para tanto.

A máquina-ventilador restringe a fala, a autonomia $e$ as oportunidades de experiências adequadas ao processo de desenvolvimento pessoal. Além das limitações impostas pela tecnologia e pela doença, o desenvolvimento da criança dependente de ventilador está sujeito a um prejuízo ainda maior em decorrência da inadequação da organização social de seu ambiente de convívio.

Entre tantas limitações individuais, a criança fala por si e revela seu potencial. Mediante entrevistas conduzidas por uma enfermeira inglesa, 18 crianças e adolescentes entre 6 e 18 anos relataram sua própria história. Contaram sobre a experiência de ser dependente de respirador que permite conhecer suas necessidades de saúde, educação e participação em atividades culturais e de brincadeiras. Ao relatarem necessidades próprias do processo de desenvolvimento humano, evidenciaram a capacidade de comunicar suas emoções e necessidades e o direito de tê-las atendidas (Noyes, 2000a, 2000b).

A pesquisa também demonstrou que a internação prolongada em unidade de terapia intensiva pediátrica, quando a assistência médica já não é mais necessária, é inapropriada e piora a condição de saúde e bem- estar do paciente. As crianças do estudo relataram impacto negativo muito profundo em suas vidas e de suas famílias. Elas experimentaram injustiça em relação a seus direitos e perceberam que suas necessidades humanas básicas não eram atendidas. O estudo mostrou que viver em uma UTI serviu 
para aumentar o sentimento de falta de sentido e valor à própria vida (Noyes, 2000a, 2000b).

O ambiente hospitalar, sobretudo a unidade de cuidados intensivos, está organizado para atender às demandas de manutenção da vida. O espaço é inadequado para crianças de qualquer idade e o "senso de urgência" entre a equipe dificulta ainda mais o atendimento de necessidades que não são vitais. A criança convive rotineiramente com a morte e a tristeza (Noyes, 2000b).

Ainda que o modelo biomédico adéqüe-se ao processo de trabalho do ambiente intensivo, o enfermeiro determina suas intervenções, de acordo com sua concepção de saúde e papel profissional. A partir dessas percepções, as estratégias de atenção integral podem ou não ser reconhecidas como função do enfermeiro na UTI (Cunha, 1997).

Existem vários fatores que determinam as ações do profissional, como a filosofia e a estrutura institucional, o processo de trabalho e a insuficiência do conhecimento científico e das evidências para sustentar a prática de enfermagem.

No cenário brasileiro, a escassez de pesquisas sobre a criança dependente de ventilador, assim como, o número reduzido de relatos de experiências sobre o atendimento das necessidades dessas crianças podem contribuir para a ausência de diretrizes que norteiem a assistência de enfermagem dirigida a tais crianças, especificamente, no que diz respeito a seu atendimento integral.

Neste sentido, para promover o atendimento integral da criança, embora não seja o único fator a ser modificado, o reconhecimento das necessidades infantis poderá contribuir para uma nova postura do enfermeiro frente a seu papel no atendimento à criança dependente de ventilador. 
Considerando-se que todas as crianças têm direito a cuidados que atendam às necessidades essenciais para o desenvolvimento de suas capacidades e que o cuidado cotidiano de crianças dependentes de ventilador é compartilhado entre os diversos profissionais de saúde e família, esta pesquisa buscou identificar em que medida a literatura científica tem abordado os aspectos relacionados às necessidades de promoção, manutenção e recuperação do desenvolvimento de crianças dependentes de ventilador. 


\section{Objetivos}

Com o propósito de aprofundar o conhecimento sobre a problemática exposta, o objetivo deste estudo foi identificar, dentre as ações propostas para o cuidado da criança dependente de ventilador, ações voltadas, especialmente, à promoção de seu desenvolvimento integral. Para tanto, teve como objetivos específicos:

- Identificar, dentre as publicações da literatura de saúde, textos que abordam aspectos do desenvolvimento de crianças dependentes de ventilador.

- Caracterizar as ações de cuidado realizadas ou propostas para a promoção do desenvolvimento da criança dependente de ventilador

- Analisar as ações de cuidado realizadas ou propostas para a promoção do desenvolvimento da criança dependente de ventilador, segundo o referencial de necessidades essenciais da infância.

Por acreditar na capacidade da criança dependente de ventilador e por reconhecer o enfermeiro como agente de mudança no ambiente de cuidados, considera-se que o presente estudo possa contribuir para a elaboração de propostas de cuidado integral à criança dependente de respirador. 


\section{Metodologia}

\subsection{Tipo de pesquisa}

Esta pesquisa classifica-se como exploratória, bibliográfica, com abordagem qualitativa (Gil, 1991). Visa a identificar conteúdos relacionados ao desenvolvimento infantil de crianças dependentes de ventilador na análise da literatura da área da saúde.

\subsection{Localização dos documentos}

\subsubsection{Bases de dados}

Para escolher o universo de documentos suscetíveis de fornecer informações sobre o problema levantado, procedeu-se uma busca de artigos indexados nas principais fontes de dados da área da saúde. A busca dos artigos utilizou descritores e palavras-chave pertinentes à temática da criança dependente de ventilação artificial e às necessidades de promoção, manutenção e recuperação do desenvolvimento dessas crianças. As bibliotecas consultadas fazem parte das principais bases eletrônicas no domínio da área da saúde e são as seguintes:

- PubMed - Serviço de pesquisa da National Library of Medicine (NLM) e do National Institute of Health dos Estados Unidos da América. Este serviço abrange mais de 17 milhões de citações do MEDLINE e outros jornais de artigos biomédicos, desde $1950 .^{1}$

- LILACS - Literatura Latino-Americana e do Caribe em Ciências da Saúde. É uma base de dados cooperativa da Rede BVS que compreende a literatura relativa às ciências da saúde, publicada nos países da América Latina e Caribe, a partir de 1982. Contém mais de

1 Disponível em: <http://www.ncbi.nlm.nih.gov/PubMed >(fev/2008) 
400.000 mil registros e artigos de cerca de 1.300 revistas mais conceituadas da área da saúde. Também possui outros documentos, tais como: teses, capítulos de teses, livros, capítulos de livros, anais de congressos ou conferências, relatórios técnico-científicos e publicações governamentais. Está disponível em Português, Espanhol e Inglês. $^{2}$

- EMBASE - é um serviço eletrônico da Elsevier que oferece acesso à base de dados EMBASE e MEDLINE. Inclui mais de 18 milhões de registros bibliográficos da literatura biomédica e farmacológica com resumos da EMBASE, desde 1974, e do MEDLINE, desde $1966 .^{3}$

- CINAHL - Cumulative Index to Nursing na Allied Health Literature consiste em uma base de dados voltada à enfermagem e áreas afins. Sua versão computadorizada iniciou-se em 1892. Indexa 2.737 periódicos e é complementada pela base Pré-CINAHL, que contém citações recentes em processamento. ${ }^{4}$

\subsection{Critérios de seleção dos artigos}

Os critérios e limites da pesquisa nas fontes de dados foram os seguintes:

- Idade: (zero-18 anos). A busca foi delimitada para identificar artigos cuja população incluía as seguintes faixas etárias: lactente: 1-23 meses, pré-escolar 2-5 anos, escolar: 6-12 anos e adolescentes: 13-18 anos. Todo artigo que apresentasse o recém nascido (RN) como populaçãoalvo do estudo, foi descartado em virtude da definição adotada nesta pesquisa para criança dependente de

2 Disponível em: < http://bvsmodelo.bvsalud.org/php/level.php> (fev/2008)

3 Disponível em: http://info.embase.com/embase com/about/index.shtml (fev/2008)

4 Disponível em: http://www.ee.usp.br/biblioteca/whorta/cinahl.htm (fev/2008) 
ventilador. A definição das faixas etárias como limite na busca foi necessária, pois, quando se utiliza apenas o termo "criança" os resultados ficam restritos a artigos da faixa etária de 6 a 12 anos.

- Idioma: a busca foi delimitada por artigos nos idiomas inglês, espanhol e português.

- Ano: a busca limitou-se a um período de 10 anos de publicação, de 1997 a julho de 2007.

\subsection{Definição dos descritores}

Os descritores são termos para uso na indexação de artigos de revistas científicas, livros, anais de congressos, relatórios técnicos e outros tipos de materiais, assim como para uso na pesquisa e recuperação de assuntos da literatura científica. Cada biblioteca consultada possui coleções de termos organizados, segundo uma metodologia na qual é possível especificar as relações entre os conceitos com o propósito de facilitar o acesso à informação. Este conjunto de informações recebe o nome de "Vocabulário estruturado". Os descritores são usados, como uma espécie de filtro entre a linguagem utilizada pelo autor e a terminologia da área e, também, podem ser considerados como assistentes de pesquisa, ajudando o usuário a refinar, expandir ou enriquecer suas pesquisas, proporcionando resultados mais objetivos.

Não foram identificados descritores específicos para localizar publicações sobre a temática "dependência de ventilação mecânica" ou "dependência de tecnologia" em nenhuma das bases de dados pesquisada. Desta forma, a estratégia utilizada na busca das publicações foi identificar descritores incluídos há mais de 10 anos e que se aproximassem do tema em questão. Uma vez definidos estes descritores, eles foram classificados quanto à sua pertinência ao tema. Assim, os descritores mais enquadrados, 
aqui chamados de descritores principais, nortearam a busca, dividida em duas etapas.

A primeira etapa utilizou os descritores principais, isolados ou combinados com os demais descritores. O resultado desta busca inicial foi analisado quanto à pertinência e quantidade dos textos encontrados. Conforme o resultado da avaliação, definiu-se a necessidade ou não de uma nova busca como se descreve adiante. A segunda etapa da busca, quando realizada, utilizou o cruzamento dos descritores principais com palavraschave. A identificação dos descritores em cada uma das bibliotecas pesquisadas foi necessária, visto que estas possuem descritores próprios para os mesmos temas investigados.

\subsection{Escolha dos descritores de busca}

A seguir, os descritores utilizados para identificação em cada base de dados são apresentados detalhadamente.

PUBMED - Os descritores eleitos na base PUBMED foram os seguintes:

- Ventilators, Mechanical: Mechanical devices used to produce or assist pulmonary ventilation; ano de inclusão: 1989

- Disabled Children: Children with mental or physical disabilities that interfere with usual activities of daily living and that may require accommodation or intervention; ano de inclusão: 1998

- Respiration, Artificial: Any method of artifical breathing that employs mechanical or non-mechanical means to force the air into and out of the lungs. Artificial respiration or ventilation is used in individuals who have stopped 
breathing or have RESPIRATORY INSUFFICIENCY to increase their intake of oxygen (O2) and excretion of carbon dioxide (CO2); ano de inclusão: 1963

- Caregivers: Persons who provide care to those who need supervision or assistance in illness or disability. They may provide the care in the home, in a hospital, or in an institution. Although caregivers include trained medical, nursing, and other health personnel, the concept also refers to parents, spouses, or other family members, friends, members of the clergy, teachers, social workers, fellow patients, etc.; ano de inclusão: 1992

- Needs Assessment: Systematic identification of a population's needs or the assessment of individuals to determine the proper level of services needed; ano de inclusão: 1999

- Human Development: Continuous sequential changes which occur in the physiological and psychological functions during the life-time of an individual; ano de inclusão: 1978

Neste banco de dados, os descritores principais eleitos foram: "Ventilators, Mechanical", "Respiration, Artificial" e "Disabled Children", e a busca deu-se em duas etapas, já descritas anteriormente: a primeira, combinando os descritores principais com os demais e a segunda, combinou os descritores principais com as palavras-chave ventilator, ventilators, ventilation, respiration, respirator, respirators, medically fragile, home, ventilator-dependent, technology dependent.

- LILACS - Os descritores empregados na base de dados LILACS foram os mesmos da base PUBMED, porém, nesta biblioteca o descritor "respiração artificial" é sinônimo de "ventilação mecânica". 
Nesta base de dados, a busca restringiu-se apenas à primeira etapa, utilizando os descritores principais isoladamente.

- EMBASE - Os descritores eleitos na base de dados EMBASE foram os seguintes:

- Artificial ventilation - sinônimo de artificial respiration; mechanical ventilation; ano de inclusão: 1974.

- Handicapped child - sinônimo de children disabled; ano de inclusão: 1974.

- Caregiver - sinônimo de Caregivers; ano de inclusão: 1990

- Os descritores Needs Assessment e Human Development foram incluídos na base de dados apenas em 2006 e, por isso, não fizeram parte dos descritores utilizados. A busca de dados nesta base usou as duas etapas descritas.

- CINAHL - nesta base de dados, foi usado o descritor "Ventilator Patients" que se mostrou suficiente para rastrear as publicações referentes ao tema, porém foi necessário incluir um limite "artigos de jornal" para a busca. A busca deu-se em uma única etapa.

- Ventilator Patients - Includes both ventilator-dependent and ventilator-assisted patients; ano de inclusão: 1991

Para cada base, foi criada uma planilha na qual as publicações encontradas foram registradas, de acordo com a estratégia de busca utilizada. O registro dos artigos continha informações, como nome do periódico, nomes dos autores, título, ano de publicação e grupo temático. Cada artigo recebeu codificação para identificá-lo na planilha, evitar duplicidade de documentos e identificar os documentos nas próximas fases do estudo. 


\subsection{Seleção dos artigos}

\subsubsection{Escolha dos documentos}

Inicialmente, os resumos de cada texto foram lidos e, de acordo com seu enfoque global, foram organizados em grupos temáticos. As publicações que não continham resumos disponíveis foram excluídas nesse momento. Os 550 artigos, cujos resumos foram lidos, distribuíram-se em 17 grupos temáticos que podem ser vistos nos dados do Quadro 1.

QUADRO 1 - GRUPOS TEMÁtICOS IDENTIFICADOS COM BASE NA LEITURA DOS RESUMOS DOS ARTIGOS ENCONTRADOS.

\begin{tabular}{|c|l|}
\hline Número & Grupo temático \\
\hline 01 & Processo de transição do hospital para casa/comunidade \\
\hline 02 & Experiência da criança e da família \\
\hline 03 & Interação criança-cuidador \\
\hline 04 & Qualidade de vida \\
\hline 05 & Proteção e segurança \\
\hline 06 & Artigos de revisão \\
\hline 07 & Mapeamento e caracterização da população \\
\hline 08 & Serviços, recursos e custos \\
\hline 09 & Modelos de assistência de enfermagem \\
\hline 10 & A criança não é dependente de Ventilação Mecânica \\
\hline 11 & Causa/Fator que determina a ventilação prolongada \\
\hline 12 & Avaliação da capacidade respiratória \\
\hline 13 & Metodologia de pesquisa \\
\hline 14 & Traqueostomia com ventilação espontânea \\
\hline 15 & Terapêutica ventilatória e farmalógica \\
\hline 16 & Temática não é específica para dependência de ventilação \\
\hline 17 & Bioética e final da vida \\
\hline
\end{tabular}


Com base na leitura dos resumos e em sua classificação nos grupos temáticos, observou-se que vários desses grupos tinham como enfoque temas não relacionados diretamente ao objetivo do estudo. Assim, a seleção dos grupos temáticos considerou a regra de pertinência de Bardin (1977), sendo eleitos para análise os que possivelmente continham documentos com informações relacionadas às perguntas da pesquisa, ou seja, os grupos temáticos de 1 a 6.

\subsubsection{Análise dos documentos}

Seguindo o modelo metodológico de análise de Bardin (1977), a análise temática divide-se em três etapas: (1) Pré-análise, que consiste na organização do material, (2) Exploração do material, que abrange os procedimentos de codificação, classificação e categorização; e (3) tratamento dos dados obtidos e a interpretação, quando são estabelecidas relações entre os dados, buscando-se desvendar o conteúdo que eles possuem.

\subsubsection{Pré-análise - Escolha dos documentos a serem analisados}

A pré-análise consistiu na organização dos artigos encontrados para permitir a seleção daqueles que comporiam o estudo, isto é, o Corpus, entendido como "... o conjunto dos documentos tidos em conta para serem submetidos aos procedimentos analíticos" (Bardin, 1977, p.96).

A definição dos grupos temáticos estabeleceu quais artigos seriam lidos e avaliados na íntegra. Iniciou-se a busca dos documentos em sua versão completa nas bibliotecas nacionais e internacionais, utilizando o meio eletrônico, como principal ferramenta para obtenção desses documentos. 
Depois de localizados os artigos, a primeira leitura, ou leitura "flutuante" foi realizada. De acordo com Bardin (1977), consiste em um procedimento pelo qual o pesquisador, de posse dos documentos escolhidos, inicia um processo de leitura e análise do material, "deixando-se invadir por impressões e orientações". Nesta etapa, os documentos foram avaliados quanto à sua adequação aos grupos temáticos estabelecidos com a leitura dos resumos, conforme já descrito.

Esta avaliação buscou adequar as publicações à regra de homogeneidade de Bardin (1977), pois esta orienta que os documentos retidos devem ser homogêneos e precisam atender aos critérios de busca estabelecidos. Assim, alguns artigos foram realocados dentro dos grupos temáticos e outros excluídos. Os motivos que levaram à exclusão dos artigos foram três: (1) artigos em que a população estudada juntava adultos e crianças e os resultados não apareciam discriminados; (2) artigos que abordavam vários grupos de crianças dependentes de tecnologia e não especificamente o grupo de crianças dependentes de ventilador; e (3) artigos em cujos resumos não foi possível identificar quaisquer referências à criança e a seu desenvolvimento.

QUADRO 2 - DISTRIBUIÇÃO DAS PUBLICAÇÕES IDENTIFICADAS, LOCALIZADAS E EXCLUÍDAS APÓS AVALIAÇÃO.

\begin{tabular}{|l|c|c|c|c|}
\hline \multirow{2}{*}{ Grupo temático } & \multicolumn{4}{|c|}{ Publicações } \\
\cline { 2 - 5 } & I dentificadas & Localizadas & Excluídas & Selecionadas \\
\hline $\begin{array}{l}\text { Processo de transição do } \\
\text { hospital para } \\
\text { casa/comunidade }\end{array}$ & 16 & 15 & 1 & 14 \\
\hline $\begin{array}{l}\text { Experiência da criança e da } \\
\text { família }\end{array}$ & 16 & 15 & 6 & 9 \\
\hline Interação criança-cuidador & 8 & 7 & 0 & 7 \\
\hline Qualidade de vida & 4 & 3 & 2 & 1 \\
\hline Proteção e segurança & 4 & 4 & 3 & 1 \\
\hline Artigos de revisão & 4 & 3 & 0 & 3 \\
\hline Total & 52 & 47 & 12 & 35 \\
\hline
\end{tabular}


Para que o material pudesse ser submetido à análise, foi elaborado um instrumento que permitiu seu preparo, sendo estruturado em duas partes: a primeira, para análise textual e a segunda, para armazenar as informações para a análise de conteúdo. Os primeiros itens do instrumento servem para organizar as informações catalográficas dos documentos e são os seguintes: (1) Dados de identificação do documento e (2) Informações sobre os autores. O item (3) identificado no instrumento como "Esquematização do documento", contempla as seguintes informações: tipo de estudo, localização geográfica e ambiente de pesquisa. O item (4) identifica os participantes do estudo, o item (5) destina-se a dados que caracterizam a criança sobre a qual os estudos se referem e o sexto, 0 último tópico é a transcrição do resumo do documento. A segunda parte do instrumento possui espaço para transcrição dos trechos recortados dos textos para análise.

\subsubsection{Elaboração dos indicadores - Seleção dos recortes}

Os documentos foram analisados buscando identificar trechos que apresentassem qualquer referência à criança e a seu desenvolvimento. Os aspectos que nortearam estes recortes foram, por exemplo, o ambiente em que a criança vive ou recebe cuidado, o relacionamento estabelecido com seus cuidadores, como suas necessidades de desenvolvimento são atendidas por seus pais, profissionais de saúde e pela sociedade. Estes recortes foram realizados em qualquer parte do artigo, transcritos para 0 instrumento de análise e identificados por meio de codificação no instrumento e no texto de origem.

Estes trechos e recortes compuseram o grupo de informações que efetivamente sofreram o processo analítico posterior, ou seja, foram codificados e categorizados, seguindo os passos da análise temática. 
Cabe ressaltar que todos os documentos selecionados estavam em inglês. Desta forma, os trechos recortados foram traduzidos pela pesquisadora e validados por um especialista na língua inglesa. A versão traduzida desses trechos seguiu para os processos de análise subseqüentes.

\subsubsection{Exploração do material}

Nesta etapa, os recortes foram codificados, ou seja, submetidos a um processo pelo qual os dados foram transformados e agregados em unidades de significação (tema). A codificação permite uma descrição precisa das características do conteúdo e visa a alcançar um núcleo de compreensão do texto. Em seguida, estes códigos foram agrupados por semelhança, visto não haver categorias predefinidas, permitindo que estas surgissem espontaneamente. Categorização é o processo de agrupar códigos que pareçam pertencer ao mesmo tema. Este processo se repetiu para que categorias mais fracas pudessem ser reagrupadas em categorias terminais.

Bardin descreve o processo de análise de conteúdo como:

Um conjunto de técnicas de análise das comunicações visando obter, por procedimentos sistemáticos e objetivos de descrição do conteúdo das mensagens, indicadores (quantitativos ou não) que permitam a inferência de conhecimentos relativos às condições de produção/recepção (variáveis inferidas) destas mensagens. (Bardin, 1977, p.38)

Dentre as técnicas de análise, optou-se por utilizar a análise temática. De acordo com Minayo (1999), a análise temática é uma das possibilidades que a análise de conteúdo apresenta; mostra-se como uma ferramenta eficaz na busca dos "significados manifestos e latentes no 
material qualitativo". A análise temática estabelece-se como uma técnica que melhor adéqua-se à investigação qualitativa do material sobre saúde. 


\section{Resultados}

Os resultados do presente estudo estão apresentados em duas seções. Assim, na primeira, constam os dados relacionados à caracterização dos documentos analisados. Na segunda seção, estão apresentados os dados referentes à análise temática dos aspectos relacionados ao desenvolvimento infantil de crianças dependentes de ventilador.

\subsection{Caracterização da amostra}

A busca dos artigos resultou em 550 artigos, já excluídos os resultados duplicados, que foram selecionados, conforme os critérios apresentados na metodologia, resultando em 35 documentos que constituíram o corpus da análise.

A distribuição dos documentos, segundo a base de dados em que se encontravam, pode ser vista nos dados da Tabela 1.

TABELA 1 - Distribuição dos ARTIgos ANALISAdos SEgUNDO A FONTE DE DADOS EM QUE FORAM LOCALIZADOS.

\begin{tabular}{lcc}
\hline \multirow{2}{*}{ Fonte de dados } & \multicolumn{2}{c}{ Artigos analisados } \\
& $\mathbf{n}$ & $\mathbf{\%}$ \\
\hline Pubmed & 25 & 71,4 \\
Cinahl & 10 & 28,6 \\
Lilacs & 0 & 0 \\
Embase & 0 & 0 \\
\hline Total & $\mathbf{3 5}$ & $\mathbf{1 0 0}$ \\
\hline
\end{tabular}

A primeira base de dados investigada foi a PUBMED, que contribuiu com o maior número de publicações para a análise. Todos os artigos estavam no idioma inglês. A segunda base de dados que mais contribuiu com textos para a análise, foi a Cinahl cujos textos também se encontravam em inglês. Cabe ressaltar que todos os textos duplicados, ou seja, os que surgiram mais de uma vez em diferentes bases foram 
excluídos, priorizando-se a primeira base em que foi localizado. Isto justifica o elevado número de publicações provenientes da base PUBMED, já que esta foi a primeira a ser pesquisada, e justifica também a ausência de publicações na base EMBASE, pois foi a última a ser investigada.

$\mathrm{Na}$ busca na base de dados LILACS, foram localizados apenas três artigos que foram excluídos, pois constituem um dos grupos temáticos não analisados nesta etapa do estudo.

Os artigos foram publicados em periódicos internacionais, entre 1997 e 2007, e sua distribuição, conforme seu ano de publicação pode ser vista nos dados da Tabela 2.

TABELA 2 - Distribuição dos ARTigos ANALISAdos, SEgundo OS ANOS DE PUBLICAÇÃO.

\begin{tabular}{lcc}
\hline \multirow{2}{*}{ Ano } & \multicolumn{2}{c}{ Distribuição I Ano } \\
& $\mathbf{n}$ & $\%$ \\
1997 & 0 & 0,0 \\
1998 & 5 & 14,3 \\
1999 & 2 & 5,7 \\
2000 & 7 & 20,0 \\
2001 & 4 & 11,4 \\
2002 & 2 & 5,7 \\
2003 & 2 & 5,7 \\
2004 & 4 & 11,4 \\
2005 & 2 & 5,8 \\
2006 & 6 & 17,1 \\
2007 & 1 & 2,9 \\
\hline Total & 35 & 100,0 \\
\hline
\end{tabular}

Houve uma flutuação nos números de publicações no período escolhido, com média de 3,18 artigos por ano. Os anos de 1998; 2000; 2001 e 2006 são os que mais tiveram publicações para análise. Embora o número de artigos sobre o tema não seja elevado, observou-se uma constância nas publicações ao longo do período, exceto pelo ano de 1997, que não contribuiu com documentos para análise, pois todos os artigos localizados 
nesse ano foram excluídos. Em 2007, o número de artigos encontrados não representou a totalidade de publicações do ano, uma vez que a busca deuse até julho, período em que o levantamento bibliográfico foi finalizado.

Todos os artigos foram publicados em periódicos internacionais e nenhum latino-americano. Contam-se 28 periódicos entre os quais se distribuem os 35 textos analisados (Tabela 3), e só um periódico especializado em enfermagem clínica contribuiu com três artigos.

TABELA 3 - Distribuição dos artigos anAlisados, DE ACORdo COM O PERIÓDICO DE PUBLICAÇÃO.

\begin{tabular}{lcc}
\hline Periódico & Total & \\
& $\mathbf{n}$ & $\%$ \\
\hline Archives of Internal Medicine & 1 & 2,9 \\
Archives of Disease in Childhood & 2 & 5,7 \\
Canadian Journal of Nursing Research & 1 & 2,9 \\
Child: Care, Health and Development & 1 & 2,9 \\
Health \& Social Care in the Community & 1 & 2,9 \\
Intensive and Critical Care Nursing & 1 & 2,9 \\
Israel Medical Association Journal & 1 & 2,9 \\
Issues in Mental Health Nursing & 1 & 2,9 \\
Journal of Advanced Nursing & 1 & 2,9 \\
Journal of Child Health Care & 1 & 2,9 \\
Journal of Pediatric Nursing & 2 & 5,7 \\
Journal of Clinical Nursing & 3 & 8,6 \\
Kennedy Institute of Ethics Journal & 1 & 2,9 \\
Nursing & 1 & 2,9 \\
Nursing Spectrum & 1 & 2,9 \\
Nursing times & 1 & 2,9 \\
Paediatric Nursing & 1 & 2,9 \\
Pediatr Clinics of North America & 1 & 2,9 \\
Pediatr Nursing & 1 & 2,9 \\
Pediatric Rehabilitation & 1 & 2,9 \\
Pediatrics & 2 & 5,7 \\
Professional Care of Mother \& Child & 1 & 2,9 \\
Qualitative Health Research & 2 & 5,7 \\
Schweizerische Medizinische Wochenschrift & 1 & 2,9 \\
Seminars in Neonatology. & 1 & 2,9 \\
Thorax & 1 & 2,9 \\
Topics in Spinal Cord Injury Rehabilitation & 1 & 2,9 \\
The Science Journal of the American & 2 & 5,7 \\
Association for Respiratory Care & & \\
\hline Total geral & 35 & 100,0 \\
\hline
\end{tabular}


A profissão ou área de atuação dos autores dos artigos selecionados mostra uma participação expressiva do profissional enfermeiro como autor, conforme pode ser visto nos dados da Tabela 4.

TABELA 4 - Distribuição dos artigos ANALISAdos SEgUndo A ÁREA PROFISSIONAL DE SEUS AUTORES.

\begin{tabular}{lcc}
\hline Profissãolárea profissional & \multicolumn{2}{c}{ Distribuição dos artigos } \\
\hline Ciências Humanas & $\mathrm{n}$ & $\%$ \\
Enfermeiro & 1 & 2,9 \\
Enfermeiro e médico & 11 & 31,4 \\
Enfermeiro, Assistente Social & 6 & 17,1 \\
Enfermeiros, médico e psicólogo & 1 & 2,9 \\
Fisioterapeuta e médico & 1 & 2,9 \\
Médico & 2 & 5,7 \\
Médico, Ciências Humanas & 3 & 8,6 \\
Não identificado & 1 & 2,9 \\
\hline Total & 9 & 25,7 \\
\hline
\end{tabular}

O enfermeiro foi autor de $54,3 \%$ dos artigos selecionados; em $31,4 \%$ deles teve autoria exclusiva e no restante teve colaboração com outros profissionais de saúde. O médico participou como colaborador em $37,2 \%$ das publicações e foi autor exclusivo em $8,6 \%$. Profissionais, como: fisioterapeuta, psicólogos, assistentes sociais e estudiosos de ciências humanas apareceram em menor número e, na maioria das vezes, em parceria com enfermeiros e médicos. O número de artigos em que a profissão do autor não estava clara ou não existia, representou $25,7 \%$ da amostra.

Os dados demonstraram que o enfermeiro parece ser 0 profissional que mais está atento às questões do desenvolvimento da criança dependente de ventilação mecânica. Ao fazer um paralelo entre as Tabelas 3 e 4, estes dados foram ratificados, já que nas revistas de enfermagem mais aparecem artigos sobre o tema. 
Os locais onde os estudos descritos nos textos analisados foram realizados aparecem nos dados da Tabela 5 . Nota-se a prevalência de publicações nos estados americanos $(45,7 \%)$, nos países do Reino Unido $(37,1 \%)$ e Canadá $(8,6 \%)$.

TABELA 5 - Distribuição dos artigos anAlisados SEgundo O local de REALIZAÇÃO DO ESTUDO.

\begin{tabular}{lcc}
\hline País & \multicolumn{2}{c}{ Local do estudo } \\
& $\mathbf{n}$ & \% \\
\hline EUA & 16 & 45,7 \\
Reino unido & 13 & 37,1 \\
Canadá & 3 & 8,6 \\
Israel & 1 & 2,9 \\
Suíça & 1 & 2,9 \\
Não identificado & 1 & 2,9 \\
\hline Total & $\mathbf{3 5}$ & $\mathbf{1 0 0 , 0}$ \\
\hline
\end{tabular}

O alto padrão de desenvolvimento tecnológico e econômico dos países da Europa e Estados Unidos da América pode justificar o maior número de publicações, já que estes têm estabelecidos recursos e estratégias de suporte à criança e à família, como por exemplo, as unidades de transição de cuidados, unidades intermediárias entre a casa e o hospital onde a família e recursos necessários à assistência domiciliar são preparados para o cuidado da criança. A América Latina não contribuiu com artigos para a análise temática. 


\subsection{Análise qualitativa}

A análise qualitativa dos dados sobre o desenvolvimento de crianças/adolescentes dependentes de ventilador possibilitou a construção de duas categorias temáticas, a saber: 1) Concepções e práticas que resultam em cuidado desigual e 2) Potenciais de desenvolvimento efetivados versus potenciais de desenvolvimento comprometidos.

\subsubsection{Concepções e práticas que resultam em cuidado desigual}

Diferentes perspectivas sobre a criança e a dependência de tecnologia na infância produzem contextos opostos de assistência às que estão em ventilação prolongada. Os temas desta categoria evidenciam que o cuidado às crianças e adolescentes dependentes de ventilador é desigual.

Assim, os trechos apresentados abaixo foram extraídos dos documentos P146, C67, C71, P28 e trazem informações sobre a atenção destinada a crianças americanas e européias. Nota-se que o respeito aos direitos, o acesso a serviços de saúde e o cuidado variaram amplamente entre diferentes profissionais, instituições e regiões de um mesmo país.

O nível de suporte domiciliar disponibilizado para as crianças em casa alternou-se, desde ter enfermagem durante 24 horas para não receber ajuda profissional. No hospital, as necessidades de brincar, manter contato com a família e de educação formal foram parcialmente ou não foram atendidas. Houve variações no grau de autonomia e socialização da criança entre as instituições, como também nos cuidados emocionais fornecidos por enfermeiras.

Para os pais, as questões mais controversas foram a falta de eqüidade em relação à habitação e o acesso a seus filhos. Atitudes variaram amplamente, de hospitais que encorajavam os 
pais a ficar com seus filhos, sem cobrar nada, para aqueles que não forneceram qualquer tipo de acomodação para os pais. As enfermeiras nem sempre promoveram ou deram suporte ao direito do jovem dependente de ventilador viver ou manter contato com sua família. (P146)

A mãe de Jason explicou como seu adolescente foi tratado diferentemente em dois hospitais: 'Eu questionei uma das enfermeiras porque ele não estava sendo educado, onde era o serviço escolar do hospital?' Ela foi posta de lado pela consultora que the disse para não se preocupar com a educação dele. Jason lembrou-se da história e relatou o que aconteceu logo após ser transferido para outro hospital: "Um dos professores começou com as lições de matemática, e eu disse: 'Eu não posso fazer isso'. Então, ela disse: 'Porque não', e eu respondi 'Porque eu sou incapacitado', e ela disse 'bem isso não é desculpa! '”. (P146)

O suporte social e de enfermagem recebidos pelos pais em casa variou amplamente e está sumarizado nos dados da Tabela 2. Todas as famílias estavam sob o cuidado de diferentes autoridades de saúde, e os serviços fornecidos nem sempre foram consistentes com as necessidades das crianças. Duas famílias não recebiam suporte doméstico ou de enfermagem em casa, enquanto a família 7 estava planejando levar sua criança para casa com cuidados de enfermagem por 24 horas e duas horas de ajuda doméstica por dia. (C67)

Esta categoria foi construída, mediante o agrupamento de subcategorias que revelam os cenários de atenção à saúde. São elas: 1) Contexto desfavorável ao desenvolvimento global da criança dependente de ventilador e 2) Contexto favorável ao desenvolvimento global da criança. 


\subsubsection{Contexto desfavorável ao desenVolvimento global DA CRIANÇA DEPENDENTE DE VENTILADOR}

Nesta subcategoria, foram agrupadas quaisquer ações, pensamentos, situações ou experiências que dão existência a um contexto desfavorável ao atendimento das necessidades integrais da criança ou do adolescente dependente de ventilador. É desfavorável em razão do potencial de causar dano ou prejuízo à saúde e ao desenvolvimento humano. Originam-se na interação que a criança estabelece com a tecnologia, com seus cuidadores e com o ambiente de convivência. O conjunto de dados foi construído com base no agrupamento dos temas: 1) Concepç̃̃es sobre depender de ventilação artificial na infância; 2) Experiências difíceis vividas pela criança e, finalmente, 3.) Estrutura e suporte social inadequados.

\subsection{Concepções "negativas" sobre depender de ventilação artificial na infância}

Agrupam-se as concepções de pais, profissionais e criança, enfim, da sociedade que pode resultar em pensamentos e ações que negam os direitos fundamentais inerentes à pessoa, dentre estes, direito à saúde, à educação, ao lazer, à profissionalização, à cultura, à dignidade, ao respeito, à liberdade e à convivência familiar e comunitária. Abaixo, estão relacionadas as percepções sobre a dependência de ventilação artificial na infância, bem como o enfoque tecnicista dado à formação dos profissionais e pais.

\section{I - Visão da sociedade: a dependência de ventilação artificial na infância é um fardo}

O documento P146 denuncia que a dependência de ventilação na infância pode ser concebida como um "fardo" e que isto desencadeia comportamentos e ações que desconsideram o direito da criança ser ouvida, respeitada e tratada como cidadã. Esta perspectiva associa-se à sobrecarga 
que a atenção à saúde desta criança/adolescente impõe aos recursos públicos. (documentos P1, P146, P204)

É comum que um serviço seja desenvolvido para uma criança ou jovem e determinado por outras pessoas, sobretudo profissionais. (Sudbery \& Noyes, 1999). Os profissionais tendem a pensar sobre os problemas encontrados pelas crianças que são deficientes, equiparando-as a um "fardo" (Baldwin \& Carlisle, 1994). Isto pode levar a uma situação na qual o jovem é tratado como um "objeto" de preocupação ou cuidados, e não como um cidadão com direitos. As pessoas que vivem com uma deficiência, têm identificado esta atitude como uma fonte de opressão, discriminação e sentimento de não ter poder [ser desautorizado] (Shakespeare \& Watson 1998). (P146)

Como a gerência de cuidados envolve o sistema de financiamento da atenção à saúde, as crianças com necessidades especiais de saúde estão sendo ameaçadas, porque o que é geralmente necessário para crianças não atende às suas necessidades. Estas crianças foram definidas pela Divisão dos Serviços para Crianças com Necessidades Especiais de Saúde como "aqueles que têm ou estão em risco aumentado para condições médicas crônicas, de desenvolvimento, comportamentais ou emocionais e condições que exigem serviços de saúde e afins, de um tipo ou montante que ultrapassa o que é exigido por crianças em geral." (P204)

Neste contexto, há um conflito entre o valor de incluir todas as pessoas em benefícios sociais, quais acomodações e despesas são necessárias para fazer isto possível e, o desvalor geralmente posto na deficiência e dependência. (P1)

\section{II - Visão do profissional: foco na dependência}

Quando o profissional de saúde acredita que a necessidade de tecnologia ventilatória torna a criança mais vulnerável e dependente do que qualquer outra, ele assume comportamentos de controle que priorizam sua segurança física em detrimento às outras necessidades de desenvolvimento. 
Segundo o documento P36, um fator que dificulta ou, até mesmo, impede a ida da criança para casa, é a preocupação com a segurança física que desencadeia ações que resultam em conflitos com os pais, sobretudo quando há suporte para atender às necessidades da criança no domicílio.

Esta perspectiva profissional configura-se como uma barreira à independência e autonomia da criança, pois sua capacidade de exploração é percebida como risco. Os temas extraídos, também, reportam-se a cuidados centrados na deficiência e perspectiva de maior dependência e pior qualidade de vida. (documentos C24, C67, P1, P27, P36, P103, P146, P204)

Os pais disseram que as razões atribuídas para seu filho continuar hospitalizado variaram de profissionais que consideravam que eles não iriam cooperar em casa para aqueles que sentiam que sua criança estaria mais segura no hospital. Para duas famílias, foi dito que não havia possibilidade de seus filhos serem transferidos para casa e que, provavelmente, ficariam no hospital indefinidamente. Ambas [as famílias] rejeitaram esta perspectiva. Os pais de uma das crianças pediram transferência para outro hospital, e os pais da outra criança iniciaram, sozinhos, o processo de alta. Ambas as crianças estão crescendo em casa. (P36)

Gilgoff \& Helgren descreveram o elaborado regime, protocolos, contratos, restrições e treinamento para capacitar a criança dependente de um ventilador para uma pequena saída da unidade de cuidados intensivos. (C67)

Mais da metade dos pais reclamou que seus filhos foram continuamente tratados, como um caso médico e disseram que enfermeiras e médicos somente falaram sobre "o que seu filho não poderia fazer e não o que eles poderiam fazer". Os pais desejavam que seus filhos fossem reavaliados regularmente e não abandonados, semana após semana, sem que nada acontecesse. (P146) 


\section{III - Visão dos pais: o filho dependente de ventilador é sempre crianca}

Os temas extraídos dos documentos C67, P21, P115 apontaram para uma concepção que tende a infantilizar ou considerar como, especialmente frágil, o filho dependente de ventilador. Como resultado, os pais passam a fazer escolhas e decidir pela criança que é, então, privada de estímulos para vencer as próximas etapas de desenvolvimento. 0 crescimento foi mencionado como algo que pode expor a criança a experiências de rejeição, em especial, na fase da adolescência quando o interesse pelo sexo oposto aumenta, conforme foi relatado por uma mãe. (P115). A percepção de que a criança é especialmente frágil está associada à condição clínica da criança.

Durante as entrevistas, qualquer que fosse a idade de sua criança, pais constantemente se referiam a ela como "criança". (C67)

.... Penso que um dos maiores erros que fizemos, desde o início, com essa coisa toda foi que falamos por eles. Tomamos todas as decisões por eles. Nós realmente não lhes demos escolha em nada. E só mais tarde, agora nos últimos anos, nós começamos perceber que eles não eram mais bebês. Porque, na minha mente, eles ainda eram meninos pequenos. Eles são adultos agora e é hora de começar a deixá-los tomar decisões. (P21)

Uma mãe descreveu os sentimentos quando sua criança pegou um resfriado: "Sentíamos um nó no estômago, pois ele tinha secreção... seus pulmões iam colapsar. Este é o primeiro momento, desde setembro em que podemos relaxar. Se ele começa a ter algo, sentimos aquele nó no estômago. Nós estamos nos sentindo como se fôssemos literalmente vomitar". (P115)

Outra mãe falou de suas preocupações à medida que sua filha se aproximava da adolescência: "Talvez, em algum momento, ela irá se interessar por um garoto e por causa do jeito que ela é, o 
garoto não vai estar interessado. Meu outro filho..., existem garotas por aí e, algumas delas, ele acha atraente. Se elas não quiserem nada com ele, ele não precisa imaginar que é porque ele é diferente dos outros. Ela terá isto. Crescimento, adolescência, as coisas vão ficar um pouco mais difíceis". (P115).

\section{IV - Visão da crianca/adolescente: diferente das outras criancas}

Usar o ventilador pode ser percebido pela criança/adolescente como algo que a restringe e torna-a diferente das demais. Faz a criança/adolescente sentir-se menos aceita no grupo do que o uso de equipamentos mais comuns, como a cadeira de rodas. Quando possível a criança/adolescente evita a exposição do aparelho em público, limitando sua participação em atividades sociais que evidenciam sua dependência, pois isto causa vergonha e sofrimento. A exposição é maior para aqueles que precisam de ventilação contínua $O$ documento P27 fornece dados que revelam menor satisfação de escolares e adolescentes com a dependência. (documentos C67, P21, P27, P76).

Um casal notou que sua filha não queria participar de determinadas atividades que necessitassem estada noturna, pois ficava envergonhada. A mãe afirmou: "Ela não quer ser diferente das outras crianças. Ela quer ser igual. $O$ fato dela ter de usar a máquina durante a noite não a incomoda, pois ninguém vê. Ela vai à escola e ela é como os outros..." (P21)

Embora jovens e crianças mais velhas fossem similarmente independentes e estivessem envolvidos em um número similar de atividades, as crianças mais velhas foram identificadas, como sendo significativamente menos satisfeitas emocionalmente do que crianças mais novas. (P27)

Quando solicitado para comentar sobre outras crianças que tinham de levar seu ventilador para a escola, um adolescente explicou: "Seria embaraçoso porque é um tanto confidencial. Tudo 
bem em nosso espaço privado, como nossa casa. Se você tiver que levar a escola, você terá de explicar para todos o que é, e eles poderão não entender, o que não seria legal". Quando questionado sobre estar confinado em uma cadeira de rodas e se sua vida seria ou não diferente se ele não tivesse que a usar, o ponto de referência deslocou-se, como o mesmo adolescente afirmou: "Para mim, é melhor na cadeira de rodas. Os garotos acostumam-se mais rápido com cadeiras de rodas do que se acostumariam com aparelho de ventilação. É uma coisa normal e muitas pessoas usam". (P76)

Somente uma das crianças deste estudo requeria assistência ventilatória na escola, que restringia sua habilidade para engajarse em atividades com outras. Isto freqüentemente levou-a a um sentimento de tristeza e frustração com sua limitação. (P76)

\section{V - O enfoque tecnicista do cuidado durante o processo de treinamentolaprendizado dos cuidadores}

A aprendizagem de cuidadores e pais é marcada pela ênfase dada aos aspectos médicos, à manutenção da ventilação artificial, ao atendimento de emergências e ao manuseio de equipamentos e materiais, embora se reconheça que estes aspectos não sejam dominantes no ambiente domiciliar. Um bom exemplo é o preparo dos pais que antecede à alta. No hospital, os pais recebem treinamento para prepará-los à gestão de equipamentos e cuidados especializados, mas não a outras necessidades da criança e da família. No documento $\mathrm{C} 24$, encontram-se orientações para passeios e saídas, porém estas centram-se nos equipamentos respiratórios para atendimento de emergência. Ainda que o treinamento ocorra como planejado, surgem dúvidas quando a criança é levada para casa. Espera-se que os pais assumam com competência o controle do cuidado em casa, incluindo o treinamento de novos cuidadores, mas falta-lhes preparo para lidar com a nova situação e atender os aspectos psicossociais do cuidado da criança. (documentos C24, P24, P34, P28, P204) 
Sua imensa experiência de cuidar de crianças doentes tornou os prestadores de cuidados diretos dos centros terciários inestimáveis para ensinar aos pais e aos prestadores comunitários os detalhes da provisão de cuidados e do gerenciamento de equipamentos. No entanto, prestadores de cuidados hospitalares são, geralmente, menos centrados em questões de desenvolvimento e de bem-estar ou sobre a integração do plano de cuidados ao estilo de vida da família. (P204)

O questionário incluiu mais questões que se focavam nos aspectos médicos e técnicos do cuidado, em parte pelas preocupações sobre este aspecto do cuidado, que é o que geralmente atrasa a alta hospitalar. No entanto, os comentários adicionados pelos gerentes indicaram que, embora estes aspectos sejam importantes, não deveríamos permitir que eles fossem dominantes. Isto pode ser comparado ao reconhecimento de Glendinning e Kirk (2000) da tendência para enfatizar habilidades técnicas ao preparar os pais para alta, bem como a sua sugestão de que os pais descobriram que os aspectos psicológicos de cuidar de seus filhos foram negligenciados. (P34)

Até o momento da alta do hospital local, os pais foram considerados competentes para gerenciar sua criança e usar equipamentos sofisticados, tais como: ventilador, equipamentos de ressuscitação, ambu, aspiradores, oxímetros de pulso, monitores transcutâneos de oxigênio, monitores transcutâneo de $\mathrm{CO} 2$, concentradores de oxigênio, cilindros de oxigênio, geradores de eletricidade e alarmes. As habilidades dos pais incluíram todos os aspectos do cuidado de seu filho, gerenciamento da ventilação assistida, ressuscitação cardiopulmonar, fisioterapia pulmonar e motora e, em alguns casos, cuidados com a traqueostomia. (P28)

Em relação ao cuidador profissional, recai a expectativa de competência para: conhecer a doença e as intervenções necessárias a cada patologia; conhecer as várias modalidades de ventilação; saber lidar com emergências; lidar com a criança com prejuízo de mobilidade; ter experiência em comunicação com crianças que têm necessidades 
complexas e possuir treinamento em dinâmica familiar e desenvolvimento infantil. No entanto, nem sempre a formação dos profissionais contempla tais expectativas, visto que os programas de formação são ministrados por profissionais especializados em cuidados intensivos e que cuidadores menos qualificados aprendem com os pais, como visto acima. Entre as dificuldades da prática profissional no domicílio, encontram-se: a falta de preparo para assistir os irmãos, o embate na divisão de cuidados com os pais e a ausência de preparo para atender às demandas psicossociais da criança dependente de ventilador. Atender às necessidades de desenvolvimento da criança foi apontada como ação adicional do cuidador, ou seja, deixa-se subentendido que não faz parte de seu rol de responsabilidades, secundário e, portanto, não essencial. (documentos C56, P 29, P34)

Todos os participantes estavam cuidando de crianças que tinham um irmão mais velho, que os cuidadores acreditavam ter problemas de comportamento. Eles não tinham certeza do tempo que deveriam interagir com o irmão. Eles sentiam que isto era frustrante, especialmente porque eles não tinham treinamento sobre, como lidar com surtos agressivos. (C56)

Dezoito dos vinte e um gestores (85,7\%), também, fizeram comentários, nos quais afirmavam ou se subentendia que elementos médicos ou técnicos dos cuidados não devem dominar qualquer provisão de educação. Por exemplo, um comentou que, embora os aspectos tecnológicos dos cuidados possam parecer esmagadores, uma vez que estes são dominados, as questões psicossociais do dia-a-dia envolvidas na prestação de cuidados e apoio são mais problemáticas e pesam mais para os funcionários e suas famílias. Como uma parte dos efeitos de cuidar de uma criança com necessidades complexas, três gerentes comentaram sobre a importância de se capacitar a equipe para avaliar algo da realidade de viver com uma criança que está dependente de tecnologia. Outros quatro gerentes consideraram que as necessidades dos irmãos dessas crianças poderiam ser 
especificamente abordadas. Alguns participantes fizeram comentários adicionais sobre a necessidade de se incluir a negociação dos limites dos papéis de cada parte envolvida. (P34)

Os cuidadores escolhidos podem, também, participar das necessidades de desenvolvimento e emocionais da criança ou assistir com home care e gerenciar os irmãos. (P29)

\subsection{Experiências difíceis vividas pela criança}

Os temas descrevem as experiências difíceis vividas pela criança dependente de ventilador durante sua trajetória de vida. Compõem-se dos relatos dos pais, profissionais e das próprias crianças/adolescentes sobre as interações entre a criança e o espaço físico de cuidados, como também sobre as relações que elas estabelecem com seus cuidadores profissionais e seus pais.

\section{1-A experiência de tornar-se dependente de tecnologia médica e de cuidados complexos}

O início da dependência tecnológica pode acontecer em distintas fases do desenvolvimento, desde o nascimento, ou de forma abrupta por ocasião de um acidente ou adoecimento inesperado. A experiência de tornar-se dependente da tecnologia médica e dos cuidados complexos exige que a criança submeta-se a intervenções cirúrgicas, exames especializados, procedimentos dolorosos, internações em unidades de cuidados intensivos que podem ser compreendidos como momentos de intenso sofrimento. Para crianças maiores, permanece a lembrança dos momentos de medo e incerteza. Elas precisam enfrentar o medo da própria morte e conviver com novas limitações, como a perda da comunicação. (documentos C42, C67, P204) 
Uma menina de 12 anos, admitida por fusão espinhal, necessitou de tração com halo por três meses para estabilizar seu pescoço no pós-operatório. Ela desenvolveu consolidações persistentes no lobo inferior esquerdo, complicando seu desmame respiratório, que não responderam ao antibiótico intravenoso convencional e à fisioterapia respiratória. Seqüencialmente, Mycobacterium tuberculosis foi isolado no aspirado endotraqueal. Ela permaneceu em suporte ventilatório até que sua tuberculose pulmonar fosse adequadamente tratada e necessitou de uma traqueostomia para facilitar a recuperação. Durante o processo de desmame, tentouse reduzir o suporte ventilatório durante o dia, a fim de fortalecer seus músculos respiratórios. (C42)

Crianças, que eram maiores de dois anos (na época de internação na UTI), relataram memórias vívidas de estar em uma unidade de cuidados intensivos. Por exemplo, uma criança que tinha três anos de idade na época (da hospitalização) disse: "Eu fui atropelado, um carro me pegou... Eu fui para (nome do hospital) em um helicóptero... e eles colocaram aquelas coisas horríveis em meu nariz. Coisa horrível aqueles tubo". (C67)

... foi encaminhada para o psicólogo que, com a ajuda de um intérprete, determinou que a menina tinha muito medo da morte até porque os lençóis do hospital lembravam o velório de sua querida avó. (C42)

\title{
II - A experiência de viver períodos longos e desnecessários no hospital
}

\begin{abstract}
A estabilização clínica da doença de base pode ser feita em pouco tempo, porém crianças estáveis permanecem hospitalizadas por períodos longos. Pais, crianças e profissionais consideram excessivo e desnecessário o tempo no hospital, esperando a transição para cuidados domiciliares.
\end{abstract}

A alta hospitalar requer muitas e longas etapas e, este processo está atrelado à estrutura e suporte social de cada país. Ao que parece, o 
processo estende-se, além do que é necessário, em razão das burocracias e lentidão nas tomadas de decisão. O documento P36 apresenta vários fatores que atrasam a ida da criança para casa, entre estes, a indecisão do profissional de quando iniciar o processo, mesmo que a criança atenda aos critérios de alta, já estabelecidos. Esta barreira foi apontada como fonte de conflitos pelos pais.

As etapas do processo de alta são: determinar se a criança atende aos critérios de alta, avaliar a capacidade da família e sua moradia, avaliar os recursos existentes na comunidade, transferir a criança da unidade de cuidados intensivos para uma unidade de transição de cuidados ou semelhante, escolher o ventilador e determinar a necessidade de outros equipamentos, determinar a necessidade e selecionar serviços de apoio ou cuidadores domiciliares, capacitar dois familiares para o cuidado, solucionar problemas na moradia e obter recursos financeiros.

Viver no hospital, sobretudo, em uma unidade de cuidados intensivos, foi referido nos documentos C24, C67, C71, C72, C76, C77, P13, P24, P29, P34, P36, P58, P62, P78, P103, P146, P204, como uma experiência que traz prejuízos e insatisfação às crianças e adolescentes, pois eles não precisam nem querem estar ali.

As crianças estiveram no hospital por períodos prolongados aguardando alta por um máximo de quatro anos. O tempo médio de espera no hospital foi de 513 dias. (P13)

Durante o período agudo de sua doença, a criança é admitida no hospital e necessita de intervenções médicas e tecnológicas, visando a estabilizar sua condição. A estabilização de sua condição médica subjacente pode, freqüentemente, ser alcançada em um curto período. (C71)

Exceto um, todos os jovens deste estudo, disseram que gastaram muitos meses no hospital (e, em alguns casos, anos), esperando 
sua alta ser organizada. Quase todos os jovens neste estudo permaneceram no hospital, quando eles não mais queriam ou necessitavam. (P146)

\section{III - A experiência de viver em um ambiente restritivo, monótono, solitário e ao mesmo tempo assustador}

Outro aspecto importante de sua experiência é a interação que a criança estabelece com o espaço físico onde é cuidada. O cenário de cuidados intensivos foi descrito por crianças e cuidadores, como um ambiente restritivo, pois limita a possibilidade de desenvolvimento da autonomia, independência, controle e socialização. A unidade de cuidados intensivos pediátricos não foi projetada para que a criança pudesse realizar atividades diárias peculiares à vida social, como: banheiros com vasos sanitários e mesas para alimentação. Os profissionais exerciam forte vigilância e controle dificultando os passeios e limitando a autonomia da família. Neste cenário, a necessidade de brincar e fazer amigos não foi assegurada. Em parte, pela forma que o cuidado e o ambiente são planejados e pela gravidade que outras crianças são admitidas para cuidados intensivos.

Diariamente, crianças estáveis convivem com a sensação iminente de perigo, com a falta de leitos intensivos, como também com a morte de outras crianças. Pais e profissionais preocupam-se com o efeito desse ambiente no desenvolvimento da criança dependente de ventilador. (C67)

Elas, geralmente, passaram muitos de seus dias, olhando toda a cena da unidade de cuidados intensivos. As crianças com quem elas poderiam interagir apresentavam severas limitações, pois a maioria era criticamente doente ou inconsciente. Estas crianças normalmente ocuparam espaços de leitos adjacentes e nunca permaneceram por muito tempo, uma vez que crianças estáveis saíram rapidamente da unidade de cuidados intensivos. As oito crianças que foram assistidas em unidade de cuidados intensivos 
para adultos raramente tinham contato com outras crianças de sua própria idade. (C67)

Uma criança mais velha expressou ampla consciência dos problemas como leitos de cuidados intensivos insuficientes e a morte de outros pacientes. Por exemplo, um adolescente explicou que ele e outros dois pacientes foram colocados dentro do espaço de dois leitos. Ele disse: "Inicialmente, o cara na minha frente morreu, então, eu ocupei seu espaço de leito". Isto é sustentado por evidências na literatura. Gemke et al (1995) relataram mortalidade de $7,5 \%$ em crianças admitidas em sua unidade de cuidados intensivos. De acordo com as estatísticas de Gemke et al, em uma unidade de cuidados intensivos de dez leitos que admite 468 crianças por ano, uma criança dependente de ventilador poderá testemunhar o trauma emocional da aflição dos parentes e do clima associado com a morte de uma criança em 35 ocasiões. Eles poderiam também presenciar 433 crianças estáveis (algumas em mais que uma ocasião) saindo da unidade de cuidados intensivos enquanto eles permanecessem parados ali. (C67)

Aquelas crianças que receberam cadeiras de rodas elétricas apresentaram novos desafios para enfermeiras, haja vista que a unidade de cuidados intensivos pediátricos não é um ambiente apropriado ao domínio do controle correto da direção e propulsão. Uma vez móvel, o jovem queria experimentar um nível de liberdade fora da unidade que os funcionários poderiam não suportar. Ter um jovem dependente de ventilador que quer sair da unidade de cuidados intensivos e encontrar outras crianças foi apontado pelos pais como a causa de problemas significativos com enfermeiras em termos de definição de riscos aceitáveis e permissão para a criança (e pais) recuperarem o controle. (67)

\section{IV - A experiência de não ser compreendido em sua forma de comunicacão}

Dentre as experiências difíceis vividas pela criança dependente de ventilador, está a de não ter sua forma de comunicação compreendida 
pelos profissionais. Os pais e as crianças identificavam os seguintes motivos: os profissionais não estão preparados para atender crianças com alterações de fala e falta acesso aos sistemas de comunicação apropriados para a necessidade da criança dependente de ventilador. Uma dificuldade adicional de comunicação se estabelece, quando o idioma da criança não é compreendido pelos profissionais. Assim, embora ela seja capaz de manifestar suas opiniões e decisões, a criança fica impossibilitada de validálas, pois estas manifestações não são decodificadas. (documentos C42, C67, P146)

As famílias reconheceram que as opiniões de pessoas jovens talvez sejam diferentes da opinião dos pais e profissionais. Neste estudo, os jovens nem sempre tiveram acesso a um sistema de comunicação que se adaptasse a suas necessidades, e eles não puderam expressar livremente sua visão. Eles nem sempre tinham contato com enfermeiras que entendiam a forma com que eles se comunicavam. (P146)

Eles disseram que foram examinados posteriormente por enfermeiros e médicos que nem sempre entendiam a forma como eles se comunicavam. (C76)

A criança, ainda mais isolada, pelo fato de que falava muito pouco inglês... (C42)

\section{$\underline{V}$ - A experiência de não ser respeitada e tratada como} pessoa

A experiência de não ser respeitada e tratada como pessoa diz respeito a situações em que seus cuidadores não asseguram o direito da criança ser ouvida, de participar de decisões e obter informações. Além destas situações, agrupam-se nesta subcategoria práticas que o profissional desqualifica, desvaloriza e não protege a criança. (documentos C42, C67, P36, P146). O documento P146 fornece evidências de que os direitos da 
criança dependente de ventilador e de suas famílias não são respeitados e que adolescentes e pais não conhecem seus direitos.

Muitos jovens, que poderiam comunicar-se, afirmaram que suas opiniões, simplesmente, não foram consultadas. Houve uma grande frustração na forma com que eles foram tratados: Que tipo de ser humano trata outro ser humano desse jeito? (P146)

A uma criança pequena pode faltar qualquer sentimento de segurança dentro deste espaço grande, e pode não ser capaz de proteger-se ou contra intrusões não autorizadas (especialmente, se elas têm um déficit de comunicação, não podem andar e não têm seus pais presentes). Por exemplo, um pai descreveu uma situação na qual um estranho abordou seu filho que não podia falar ou andar. Ele não se apresentou, pegou um pouco de sangue da criança com agulha e seringa e, então, foi embora. (C67)

O jeito que os jovens foram tratados, por enfermeiros e médicos, foi destacado por várias crianças mais velhas durante a entrevista. Um adolescente resumiu um típico sentimento: "Você não pode ter um (prejuízo físico) sem o outro (dificuldade de aprendizagem)". Ele sentiu que foi consistentemente tratado como se tivesse dificuldade de aprendizagem porque ele tinha uma lesão medular. (C67)

\section{VI - A experiência de viver as barreiras à formação de vínculo com seus pais}

Em algum estágio de seu desenvolvimento, a criança dependente de ventilador passa períodos longe de sua casa, sendo cuidada em hospitais por pessoas que não são seus pais. Assim, a distância entre o hospital e a casa, os períodos prolongados de hospitalização, a falta de apoio para permanecer com a criança hospitalizada, a falta de privacidade entre pais e filhos e o "senso de propriedade" que enfermeiras assumem sobre as crianças são fatores identificados, no documento C67, que impedem ou dificultam a formação de vínculo entre pais e filhos. 
Os pais achavam que a maior parte do cuidado para estabelecer ou restabelecer um relacionamento significante com seu filho foi feito em público, freqüentemente, com uma enfermeira muito próxima e observada pela multidão de pessoas que trabalhava ou visitava a unidade de cuidados intensivos. Esta foi classificada como uma experiência muito negativa e emergia como uma barreira significativa que impedia os pais de gastarem mais tempo com suas crianças. Algumas mães sentiam-se separadas de seus filhos mais velhos e sentiam que eles não Ihes pertenciam mais. Isto teve um efeito duradouro e nem sempre reverteu com o tempo. (C67)

De acordo com Cagen (1998), existe uma dependência artificial dos pais das enfermeiras que freqüentemente ocorre com hospitalização infantil prolongada. No atual estudo, esta dependência tomou três formas. Primeiro, pais de crianças dependentes de ventilador tiveram que permitir que enfermeiros cuidassem de seus filhos em sua ausência. Segundo, os pais foram dependentes de enfermeiras para thes ensinar como cuidar de suas crianças. Terceiro, enfermeiros definiram as regras sobre o que os pais podiam ou não podiam fazer com suas crianças. (C67)

Todos os pais entrevistados tinham de fazer esforços para manter contato regular com sua criança. Para as cinco famílias (deste estudo), não foram oferecidas acomodações no local e estas tiveram de alugar acomodações próximas ao hospital. (C67)

\section{VII - A experiência de viver as barreiras à formação de vínculo com seus cuidadores (profissionais)}

Nesta subcategoria, reúnem-se as características do cuidado fornecido pelos profissionais que se constituem como barreiras à formação do relacionamento de confiança com a criança. Dos documentos C67, C71, $\mathrm{P} 18, \mathrm{P} 146$, foram extraídos os fatores que impedem ou dificultam a formação de vínculo entre a criança e o profissional, como: o cuidado de enfermagem centrado na patologia e em cuidados físicos; a organização do 
cuidado fornecido na unidade de cuidados intensivos; a troca intensa de cuidadores e as barreiras que se estabelecem na própria interação, como por exemplo, incongruências entre mensagens verbais e não-verbais, proposição de ações incompatíveis à condição da criança, desatenção e cansaço físico.

...Uma preocupação importante foi o dano causado durante este tempo à capacidade da criança formar relacionamentos significativos e vínculos com adultos. (Rutter \& Rutter 1992). Quase todos os jovens não tiveram enfermeiras dedicadas e foram cuidados por inúmeras enfermeiras que vinham e iam a cada plantão. (P146)

Funcionários são confrontados com a pressão de admissões agudas e, por isso, a criança cronicamente ventilada pode, freqüentemente, lidar com inconsistências nos cuidados, quer seja o excesso ou a falta de estimulação e falta de acesso a experiências normais para seu desenvolvimento. Isto não é compatível com as necessidades dinâmicas e complexas a longo prazo de uma criança em desenvolvimento (Warner e Norwood 1991). (C71)

Comportamentos de desatenção incluem: estar atrasado, dormir tarde, não estar disponível para ajudar o acampante com o cuidado matutino, retirar-se ou pedir a outros para participar e assumir o cuidado do acampante. (P18)

\subsection{Estrutura e suporte social inadequados}

Reúnem-se temas relacionados à deficiência de estrutura e suporte social para o atendimento das necessidades de saúde da criança dependente de ventilador e que estão diretamente relacionados ao espaço de convivência da criança e à assistência que recebe. 


\section{I - Faltam equipamentos que permitam mobilidade e socialização}

Particularmente, o documento C67 descreve que a falta de equipamentos apropriados, tais como, ventilador portátil e cadeiras de rodas elétricas, configura-se como barreira à mobilidade e socialização da criança dependente de ventilador.

Neste estudo, muitas das crianças que requeriam 24 horas de ventilação foram imobilizadas pela falta de ventilador portátil e permanentemente viveram dentro do espaço de leito designado na unidade de cuidados intensivos. (C67)

Uma característica em comum de todas as crianças que requeriam 24 horas de ventilação foi a longa espera (em alguns casos anos), antes do ventilador portátil estar disponível. Uma particular fonte de frustração para jovens com lesão medular ou distúrbios neuromusculares foi não ter tido uma cadeira de rodas que pudesse acomodar um ventilador portátil. Algumas crianças teriam se beneficiado se tivessem uma cadeira de rodas elétrica, que elas próprias pudessem operar. (C67)

\section{II - Faltam servicos e profissionais que promovam reabilitação}

A despeito dos longos períodos de permanência da criança/adolescente no hospital, os recursos disponibilizados para sua atenção não abrangem aspectos da reabilitação. O documento C67 menciona a falta de dispositivos e serviços especializados para reabilitação da fala, a falta de estrutura física e serviços de reabilitação, a falta de acesso a programas de escolarização e a falta de capacitação dos profissionais para lidar com a questão.

Nove crianças maiores, falando, se submeteram à realização da traqueostomia, após a injúria medular. As crianças não tiveram acesso rotineiro ao fonoaudiólogo, terapia de comunicação e 
linguagem e nem sempre foram fornecidos dispositivos para ajudá-las na sua comunicação. (C67)

Muitas crianças que eram elegíveis, não recebiam educação estatutária na unidade de cuidados intensivos. Para a maioria das crianças, a educação foi esporádica, porque havia enfermeiras de cuidados intensivos insuficientes para permitir que elas saíssem da unidade de cuidados intensivos. Professores hospitalares não foram simplesmente preparados para entregar o curriculum nacional, e várias crianças não puderam usar a sala escolar do hospital, pois era inacessível. (C67)

Os pais sentiam que existia pouco progresso nos hospitais onde a estabilização médica inicial tinha sido completada e nada mais havia sido oferecido em termos de reabilitação. Eles sentiam que médicos e enfermeiros das unidades de cuidados intensivos não estavam treinados, como especialistas em reabilitação. (C67)

\section{IV - Faltam servicos e profissionais qualificados para a atenção cotidiana}

A atenção cotidiana da criança/adolescente dependente de ventilador deixa a desejar, seja pela escassez e competência dos serviços, como também pelo déficit de profissionais capacitados para seu atendimento, tanto no âmbito hospitalar como domiciliar. Os documentos C24, P34 e P103 mencionam que, em países como Estados Unidos da América e Inglaterra, a falta de enfermeiras para o cuidado domiciliar é uma barreira ao processo de transição, o que leva a aumentar a permanência da criança em unidades hospitalares.

Esta carência foi apontada como um dos motivos para manter cuidadores menos qualificados prestando-Ihe assistência em casa, bem como, para impedir que a criança em ventilação domiciliar freqüentasse a escola. (documento P13). Já em relação à criança hospitalizada, o número de profissionais foi insuficiente para atender às demandas de cuidados da criança estável, como, brincadeiras e passeios. 
Além disso, uma minoria das unidades de cuidados intensivos contava com psicólogos infantis na equipe. A falta de enfermeiras na UCIP, também, foi apontada como um fator de risco à criança em cuidado domiciliar, visto que o preparo dos pais pode ser realizado por profissionais com pouco tempo para dedicar-se a essa tarefa. Há falta de ambientes alternativos de cuidados, como por exemplo, unidades de transição de cuidados e serviços que atendam a crianças e adolescentes que precisam de hospitalização. Destaque foi dado ao mau gerenciamento do processo de alta, como resultado da má prática e da escassez de recursos. (documentos C42, C67, P36, P146, P204)

Recrutamento de enfermeiras pediatras treinadas é um problema nacional e é causa do atraso na alta destas crianças. (P103)

Das quinze crianças, treze eram maiores de três anos de idade e com direito à educação formal. Seis das 15 crianças participaram da escola regular, com o restante tendo provisão de serviços que atendiam às necessidades especiais por uma parte da semana. Todas as crianças necessitavam de cuidados adicionais nos ambientes escolares. $\mathrm{Na}$ verdade, atrasos para a criança freqüentar à escola são decorrentes das dificuldades para recrutar e treinar cuidadores. (P13)

Quase todas as insatisfações decorriam de quando se tornou evidente que eram incapazes de sair da ventilação mecânica e respirar independentemente por todo ou parte do dia. Muitos fornecedores de serviços de saúde foram hesitantes e incapazes de admitir um jovem dependente de ventilador. Os jovens descreveram transferências para até quatro hospitais diferentes, alguns dos quais se localizavam a centenas de milhas de casa. Quase todas as famílias descreveram exemplos de cuidado e tratamento incompetentes. (P146)

\section{V - Falta suporte domiciliar adequado às necessidades da crianca e de seus pais}


Um dos obstáculos para o cuidado domiciliar de qualidade é o fornecimento de assistência domiciliar em número de horas condizentes às necessidades da criança e de seus pais. Durante o processo de alta, os pais travam verdadeiras batalhas para conseguir serviços, recursos tecnológicos, suporte financeiro e levar a criança para casa. Em razão do déficit de serviços e profissionais, os pais são preparados e treinados para assumir a responsabilidade dos cuidados domiciliares de forma contínua ou parcial, o que resulta em sobrecarga financeira, física e emocional.

Os pais sentem-se sozinhos porque têm pouco contato com os serviços de acompanhamento da saúde da criança. Assim, os serviços que fornecem cuidadores para a substituição temporária dos pais, são escassos e providos de normas que os resguardam de responsabilidades. Outros aspectos associados a dificuldade de substituição dos pais no cuidado, são: ausência de outras pessoas da família capacitadas para o cuidado e o despreparo dos profissionais de saúde. Os documentos P19 e P20 destacam que o suporte social é o fator que tem maior impacto na saúde mental dos pais. Pais de crianças dependentes de ventilação, sob cuidados domiciliares, são vulneráveis ao adoecimento, sobretudo, à depressão.

Além da falta de suporte profissional para o cuidado diário do filho, os pais precisam lidar com a falta de recursos da comunidade: atenção primária, transporte e serviços de atenção especializada na área onde residem. (P13, P16, P 20, P28, P34, P36, P98, P204)

No presente estudo, foi relatada ampla variação no tipo de cuidador empregado na casa da família. Doze das quinze crianças/jovens foram inicialmente transferidos para casa com cuidadores empregados. Alguns pais insistiram em ter enfermeiras altamente qualificadas da unidade de cuidados intensivos que algumas autoridades de financiamento recusaram pagar quando enfermeiros menos qualificados ou não qualificados seriam muito mais baratos. Houve, também, prolongadas disputas sobre a quantidade de cuidados de enfermagem prestados. (P36) 
Os pais da criança 1, que não recebiam suporte, disseram; "Literalmente, nós apenas tivemos que lidar com a situação e seguir em frente." Similarmente, os pais da criança 6 disseram: "Estamos amargurados, porque não recebemos ajuda alguma. Tudo que nós temos, é uma enfermeira do distrito que traz suprimentos para [nome da criança] uma vez por mês... mas você aprende e enfrenta." (P28)

Treze famílias receberam apoio de assistência domiciliar. A quantidade de assistência domiciliar variou de zero a 168 horas por semana; geralmente, foi fornecida por cuidadores domiciliares predominantemente financiados pela Autoridade de Saúde. (P13)

As fontes e os mediadores de estresse em conjunto não foram preditores significativos de depressão. A análise de regressão hierárquica foi realizada para determinar o efeito adicional de qualquer enfrentamento ou de suporte social sobre depressão nas mães (Tabela 4). Variáveis demográficas, como a idade, não foram incluídas como variáveis de controle, assim como não foram encontradas relações com depressão. Quando o suporte social foi acrescentado à regressão, este contribuiu para uma quantidade significativa de variância ( $R 2=$ mudança. 09; $p$ <.05) e foi inversamente relacionada à depressão quando o status funcional $\mathrm{e}$ impacto na família foram controlados. As mães, que relataram maior suporte social, tiveram menor pontuação nos escores de depressão. (P20)

\section{VI - Faltam recursos financeiros}

A falta de recursos financeiros, privado ou público, foi apontada pelos documentos C24, C72, P36, P204, como barreira ao processo de transição de cuidados do hospital para casa, visto que obter fundos é crucial para que a alta se efetue. Além de prolongar a permanência da criança no hospital, a falta de dinheiro compromete a prestação de serviço no domicílio. Em países como Estados Unidos da América e Reino Unido, o déficit de recursos públicos resultou em menor aprovação no número de horas de 
cuidado da enfermagem domiciliar. Os documentos C71 e P204 advertem que o custo do cuidado tem sido priorizado em detrimento da qualidade de vida, nos dilemas de alocação de recursos. As negociações para prover o suporte domiciliar focadas no custo do cuidado resultam em assistência que traz danos ao desenvolvimento infantil, como também riscos à própria vida

[Gerentes de caso] Eles são constrangidos por dólares, mas a seleção de empresas de cuidados domiciliares deve orientar-se por mais que a melhor oferta menor lance. [As negociações para alta] também deve incluir identificação de empresas com enfermeiras experientes, supervisores qualificados, bem como a capacidade de garantir recursos humanos e segurança. Isso, muitas vezes, exige experiência com as empresas na área geográfica onde a criança vai viver. Basta apenas uma internação desnecessária originada por um cuidado de enfermagem pobre para tornar a empresa mais qualificada em uma empresa de custo-benefício. (P204)

Com a escassez de serviços disponíveis e a falta de dinheiro no Estado, Medicaid não têm freqüentemente aprovado o número de horas de cuidado de enfermagem requerido. (C24)

Lantos e Kohrman (1992) descreveram a ventilação domiciliar como, talvez, a terapia domiciliar mais arriscada, cara e onerosa. Trata-se de trabalho intensivo e requer habilidades especiais. Eles notaram que a falha dos sistemas técnicos, de atenção ou de julgamento humano pode resultar na morte imediata da criança. (P204)

\section{VII - Faltam regulamentacões e normas}

Mesmo em países onde há sistemas econômicos e políticos bemsucedidos, a falta de legislação e a organização social criam impasses, atrasam a alta para cuidados na comunidade e interferem na prestação de serviços para o contínuo desenvolvimento da criança dependente de ventilador. Apontada pelos documentos C67, P13, P36, P78, P204, a falta de 
regulamentação e as normas resultam em experiências e cuidados inadequados à criança. No nível local, falta sistematização para o processo de treinamento dos pais, o que equivale em despreparo para cuidar da criança em casa.

O governo do UK reconhece que uma das grandes barreiras para fornecer um "serviço homogêneo" é a falta de recursos em conjunto e a colaboração entre vários departamentos e agências (Leathard, 1998). (P36)

Ainda que uma definição legal indicando os serviços para crianças ventiladas em casa evitasse a necessidade de mais negociações, atualmente, não existe legislação em Israel. (P78)

[...] Isto pede uma resposta especial de legisladores, de companhias que gerenciam o cuidado, aliás, da sociedade, porque o planejamento para as necessidades gerais das crianças deixa estas crianças com cuidados inadequados. (P204)

\subsubsection{CONTEXTO FAVORÁVEL AO DESENVOLVIMENTO GLOBAL DA CRIANÇA DEPENDENTE DE VENTILADOR}

Esta subcategoria inclui os temas a respeito das concepções, ações e experiências que resultam em condições mais favoráveis ao desenvolvimento infantil. Percepções mais positivas sobre a dependência de cuidados e equipamentos na infância fornecem cenário propício ao atendimento das necessidades e resultam em oportunidades para a criança desenvolver seu potencial inato. Este conjunto de dados incorpora as ações implementadas para atender às necessidades de saúde, dentre elas, as do desenvolvimento, bem como as recomendações dos autores para vencer os obstáculos nos diversos níveis de atenção. Os temas que a compõem são:

1) Concepções "positivas" sobre depender de ventilador artificial na infância, 2) Oportunidades que ajudam as crianças dependentes de ventilador 
perceberem seus potenciais, e 3) Ações de promoção à saúde integral da criança dependente de tecnologia.

\subsection{Concepções "positivas" sobre depender de ventilador artificial na infância}

Este conjunto de dados foi construído por temas que retratam as percepções de pais, profissionais, amigos e da própria criança/adolescente que vive a experiência de ser dependente de uma máquina para manter-se viva. Evidenciam perspectivas mais positivas sobre a criança e a dependência de tecnologia na infância

\section{I - Autopercepção: igual às demais crianças}

Apesar dos desafios e cuidados cotidianos, a criança ou adolescente pode ter uma visão positiva da vida e da relação que estabelece com o ventilador. Ela se vê como criança e não como uma criança deficiente. O adolescente quer ser visto um como adolescente e não gosta de ser infantilizado pelos seus cuidadores, percebe-se menos restrito em função da dependência do que os pais. Este contexto pôde ser observado nos temas subtraídos dos documentos C67, P27, P76. Nestes textos, algumas crianças não notavam a rotina de cuidados complexos e o uso do ventilador como um problema, pois, isto não as impedia viver a vida e as ajudava viver melhor, embora preferissem não depender dele. Mesmo as internações e avaliações médicas freqüentes foram avaliadas como fonte de segurança.

Desse modo, as crianças sentiam-se confortáveis com os profissionais e com o nível de conhecimento resultante. Para elas, o ventilador não ocupa uma posição de destaque, pois não centram seus interesses e preocupações na tecnologia. Seus desejos e planos para o futuro incluem: ter suas capacidades reconhecidas, livrar-se do ventilador e tornar-se alguém e, para aquelas mantidas em instituições de saúde, o 
desejo é deixar o hospital. Cabe ressaltar que os participantes, em sua maioria, dependiam do ventilador parte do dia, principalmente, para dormir.

Enquanto algumas destas crianças percebiam a necessidade de ventilação como temporária e outras, não. Todas as crianças concluíram que a tecnologia era somente uma parte de suas vidas. Elas sentiam que suas vidas eram similar a de seus pares, com exceção de sua necessidade para um ventilador para ajudálas a respirar. (P76)

Elas comentavam com freqüência, "tudo bem, me ajuda respirar. Não é um grande problema", eram expressões da aceitação da tecnologia. A tecnologia e sua doença não eram uma questão central e, somente, parte de suas vidas. Durante visitas à escola com duas das crianças, foi observado que desenvolver amizade com outras crianças de sua própria idade foi uma parte muito importante de suas vidas. Isto foi confirmado durante a entrevista com as crianças, em que elas preferiram focar em seus últimos interesses e amizades mais que na necessidade para suporte ventilatório. (P76)

É interessante observar, nenhum dos jovens neste estudo considerou-se como sendo "deficiente". (C67)

\section{II - Visão do profissional: foco na criança}

Os dados revelam a preocupação do profissional de saúde com a criança e suas necessidades. Na concepção dos autores dos documentos C57, C67, P28, P29, P34 e P76, a criança dependente de ventilador é como qualquer criança em suas necessidades essenciais, mas ela tem oportunidades diferentes para desenvolver-se como esperado.

Nesta perspectiva, o foco do cuidado é a criança. O profissional acredita que os aspectos médicos e tecnológicos são prioritários no início da dependência, mas após a estabilização clínica da criança suas necessidades integrais emergem, novamente. 
Assim sendo, ressalta-se a importância de assegurar assistência que atenda além dos cuidados da terapêutica ventilatória. Cabe enfatizar a preocupação para que a criança estável seja rapidamente deslocada para cuidados domiciliares e que estando nesse ambiente não se reproduza o contexto das unidades de terapia intensiva. Entre as recompensas de promover cuidado efetivo, destaca-se a experiência de descobrir o potencial da criança dependente de ventilador, como algo que transforma o profissional.

Ser dependente de ventilador não faz diferença para a necessidade da criança brincar e de atividades de lazer (Ahmann \& Lipsi, 1991). Brincar na infância permite às crianças oportunidades para assumir riscos, experimentar, quebrar as regras, explorar seu ambiente e, conforme elas crescem, experimentar independência sem a supervisão do adulto. (C67)

Crianças dependentes de ventilação não são doentes agudos e têm necessidades educacionais e de desenvolvimentos amplas. (Nelson et al., 1996). Apesar de ser medicamente estáveis, evidências sugerem que este grupo de crianças passa períodos prolongados de tempo em unidades de cuidados intensivos pediátricos (PICU), antes de receber alta para a comunidade (Fraser et al., 1997). (P28)

Este dia parece um sonho agora. Tudo que eu me lembro, é da música clássica, a voz suave de Anne e dos olhos azuis de Kevin. Olhando para trás dois anos mais tarde, eu ainda estou me perguntando, quais segredos estavam presos atrás daqueles olhos. Kevin era feliz? Ele poderia amar? Eu espero que sim. Eu sei que me senti próximo a ele de algum jeito. Eu não posso explicar e devo isto a ele. Eu sou um enfermeiro melhor. (C57)

\section{III - Visão dos pais: foco nas capacidades da criança}

O documento C57 descreve a interação entre uma mãe e seu filho portador de múltiplas limitações. No discurso materno, apresentado abaixo, 
observa-se o interesse em olhar para as competências e não as incapacidades. Já o documento $\mathrm{P} 27$ registra que os pais e adolescentes avaliam o estado psicológico do adolescente de maneira similar. Em síntese, a família conhece melhor a criança/adolescente do que o profissional de saúde. O cuidado apresenta-se como explicação, visto que demanda proximidade e conversas em decorrência da preocupação dos pais com 0 estado mental do filho dependente de ventilador.

A mãe de Kevin, Anne, estava indo e vindo para a unidade toda manhã. Enquanto o preceptor e eu banhávamos Kevin, trocávamos sua cama e, mudávamos seu decúbito, Anne nos contou um pouco de sua vida. Ela era uma viúva que cuidava de muitas crianças adotivas com necessidades especiais, ao longo dos anos. Ela tinha 52 anos quando adotou Kevin quando era um bebê. "Ninguém pensou que Kevin pudesse viver mais que cinco anos, mas ele enganou a todos". Anne disse orgulhosamente. "Os médicos pensam que ele é totalmente surdo, mas eu sei que ele pode ouvir um pouco em seu ouvido esquerdo. Basta observar". Ela disse. (C57)

Semelhante aos resultados anteriores com adultos $[13,14,17,1$, $20,21]$, os cuidadores primários descreveram a criança assistida por ventilador como um grupo contente, ativo e relativamente independente. (P27)

Os adolescentes e seus pais avaliaram o estado psicológico do adolescente similarmente, em contraste com os resultados das famílias de crianças com outras condições, como a lesão cerebral traumática [24]. Explicações possíveis incluem: (1), o cuidador principal (pais) destes adolescentes pode, por necessidade, passar uma grande quantidade de tempo com a criança, o que resultou em uma relação entre pai e filho mais próxima e forte congruência das respostas; (2), o estado psicológico da criança pode ser motivo de grande preocupação para a família e, portanto, é mais estreitamente monitorado e diretamente abordado por meio dos serviços de suporte fornecido à família, (3) em razão da 
natureza da deficiência da criança e das questões éticas em torno da escolha da ventilação domiciliar, a discussão dos sentimentos e do estado emocional da criança pode ser mais freqüente do que na família-padrão. (P27)

\section{IV - Visão da crianca: valor da amizade com a criança dependente de ventilador}

Outras crianças valorizam a amizade com a criança dependente de ventilador, como registrado no documento P76.

Observações na escola confirmaram o relacionamento recíproco entre as crianças, como elas foram muito respeitosas na assistência mútua e com os trabalhos escolares para aproveitar o tempo livre juntos. (P76)

\subsection{Oportunidades que ajudam as crianças dependentes de ventilador perceberem seus potenciais}

As experiências, que ajudam as crianças dependentes de ventilador perceberem seus potenciais, estabelecem-se nas interações com o ambiente, assim como, nos relacionamentos com outros indivíduos, sejam eles adultos ou crianças. Consistem em possibilidades para a criança aprender, fazer amigos, conviver com seus familiares, estabelecer relacionamentos sustentadores com outro ser humano, viver com segurança e estabelecer uma identidade própria.

\section{1-A oportunidade de freqüentar a escola}

Freqüentar a escola foi uma possibilidade para a criança/adolescente em ventilação domiciliar, conforme registros obtidos nos documentos P76 e P103. 
crianças freqüentavam a escola especial, 15 eram pré-escolares e, no caso de duas outras, sua escolaridade era desconhecida. (P103)

'Amizades, família, escola e interesses'. Quatro das crianças deste estudo freqüentavam a escola regularmente, duas totalmente integradas à sala de aula e outras duas freqüentavam uma escola para crianças com necessidades adicionais. (P76)

\section{II - A oportunidade de ser cuidada em um ambiente menos restritivo}

A oportunidade de viver e receber cuidados no ambiente domiciliar pode favorecer o desenvolvimento infantil, sempre que o ambiente fornecer estímulos adequados e segurança emocional. A casa favorece a construção da identidade e a normalização da vida. A criança convive com sua família, recebe cuidados de seus pais e participa de muitas atividades próprias para a idade, como: fazer amigos na vizinhança e brigar com os irmãos. (documentos C67, C76, C90, P1, P27, P16)

No estudo, o pesquisador visitou todos os jovens onde eles estavam atualmente vivendo. Os ambientes domésticos eram lugares vibrantes, com decorações que refletiam as identidades religiosa - cultural - étnica. Os jovens tinham seus próprios quartos, nos quais eles tinham estampado sua própria identidade. Os impactos da variedade de cores, tecidos, texturas, móveis, cheiros e sons forneciam um contraste gritante ao cheiro e aparência do hospital. Em casa, é provável que a criança entre em contato com relativamente poucas pessoas e a casa forma uma fronteira segura com o mundo exterior. (Lyth, 1982). O contato com outras pessoas e as intrusões indesejadas são freqüentemente mediados por membros da família (sobretudo, os pais). (C67)

Amanda pode não ter sido readmitida no hospital, mas ocasionalmente ela ainda retorna para exames ou para visitar 
seus amigos na unidade. Mas existe uma diferença muito importante agora. Quando a visita chega ao fim, Amanda também pode ir para casa. (C76)

As atividades em que as crianças estavam envolvidas demonstravam um amplo leque de interesses. Estes resultados são consistentes com aqueles obtidos a partir de pesquisas anteriores, indicando que os pais percebem o cuidado domiciliar para seu filho assistido por ventilador, como uma influência muito positiva sobre o desenvolvimento e bem-estar da criança. (P27)

Envolvimento absoluto representou a devoção materna demonstrada quando cuidando de seu filho e família. O objetivo deste compromisso intenso foi garantir o fornecimento de um padrão auto-determinado pela mãe de cuidado para seu filho. (C90)

\section{III - A oportunidade de receber ventilação domiciliar segura e eficiente}

Nos documentos C76, P36, P59, P76, P78 e P204, encontram-se informações que evidenciam a eficácia e a segurança da ventilação domiciliar, desde que o suporte fornecido seja condizente com as necessidades da família e da criança. Pais, participantes do estudo P36, consideraram que os incidentes que colocam em risco a vida, podem acontecer em qualquer lugar, até mesmo no hospital.

Evidências a partir de estudos longitudinais da criança dependente de ventilador na América do Norte sugerem que as crianças experimentaram poucos problemas sérios, uma vez que receberam alta para casa. No presente estudo, pais, crianças e jovens também relataram poucos problemas sérios, embora os infreqüentes incidentes nocivos que ocorreram, tenham sido muito assustadores. (Noyes, 1999). (P36) 
Todos os estudos mostram que crianças e bebês devidamente selecionados podem ser ventilados com segurança em casa. Estes estudos demonstraram que falhas no equipamento ventilador ocorrem muito raramente. Uma análise da pesquisa de 150 pacientes assistidos por ventilador em um período de um ano registrou que houve uma falha mecânica do equipamento para cada 1.25 ano de uso contínuo. (P59)

Enviar crianças que estão sob ventilação em tempo inteiro para casa ainda é relativamente novo. Amanda é único caso do Mancunian Community Health NHS Trust, há apenas dois ou três outros em Manchester como um todo. Jeanette McGrogan diz: "Ela é a única criança que está em casa por tanto tempo sem ter de ser readmitida no hospital, o que em si é um tremendo sucesso". (C76)

\section{IV - A oportunidade de participar de atividades lúdicas e de} $\underline{\underline{\text { lazer }}}$

Além de propiciar momentos de diversão e brincadeiras, o lazer promoveu vínculo entre os pares, como demonstram os documentos $\mathrm{C} 67 \mathrm{e}$ P18.

Nos alojamentos para dormir, o gênero influenciou a identidade grupal, com meninos e meninas planejando uma noite especial de diversões para aumentar a coesão do próprio grupo. Por exemplo, uma noite, as meninas tiveram uma atividade para cantar no quarto. Embora este evento tenha começado como diversão, logo isto se tornou competitivo, com crianças de outros quartos juntando-se a elas. Cantar tornou-se alto e aumentava em resposta aos outros cantores através das divisórias, separando os quartos. O grupo de meninas pequenas e seus cuidadores ficaram conhecidos por causa de suas canções e isto aumentou seu senso de identidade, tanto entre seus cuidadores especiais como entre seus pares. (P18) 
Carter (1988) descreveu como as crianças que eram dependentes de ventilação, podiam desfrutar da natação e banhos de sol como atividades divertidas. (C67)

\section{V - A oportunidade de desenvolver autonomia para o próprio cuidado}

Saber manejar o equipamento deu à criança autonomia para cuidar-se e desenvolver atividades. (documento P76)

Todas as crianças eram extremamente conhecedoras de seu cuidado médico e estavam confortáveis com isto. Uma criança cujo ventilador ficou desconectado, enquanto ela estava pintando, disse: "Apenas um minuto. Não se preocupe... tudo bem quando estas luzes laranja piscam. Isto apenas significa que está pausado. Eu ainda estou respirando" A criança continuou pintando em seu papel e após um pequeno momento, ela pegou o tubo do ventilador e reconectou-o sem qualquer ajuda. (P76)

\section{VI - A oportunidade de serem cuidadas por pais capacitados para promover segurança física}

Durante o processo de alta, os profissionais (enfermeiras e fisioterapeutas) treinam os pais para cuidar da segurança física da criança. Espera-se que a família desenvolva autonomia para assumir a responsabilidade do cuidado domiciliar. Desta forma, enquanto se capacitam, são submetidos a constantes avaliações, dentre elas, demonstrar que podem cuidar do filho sem qualquer ajuda. Durante 24 horas, a família precisa demonstrar as habilidades aprendidas, sem a assistência dos profissionais envolvidos no processo de treinamento.

Os documentos P17, P28, P103 fornecem dados que demonstram que os pais aprendem o conteúdo dos programas e tornam-se competentes para atender às necessidades de cuidados complexos. $\mathrm{O}$ treinamento e a capacitação dos pais configuram-se como possibilidades para a criança deixar o hospital e ser cuidada em um ambiente menos restritivo, além de 
receber cuidados seguros e eficientes. (documentos C24, C71, C72, P17, P24, P28, P58, P103)

Todos os pais foram inicialmente ensinados por uma enfermeira clínica especializada e designada e seguiram um programa educacional baseado na competência dos pais, o qual foi completado no hospital local (Noyes, 1990; Hartmann et al., 1994). (P28)

Pais devem demonstrar várias habilidades antes de poderem levar seu bebê para casa, incluindo: cuidados com a traqueostomia, aspiração e troca do tubo de traqueostomia, ressuscitação cardiopulmonar, conectar um nebulizador portátil e realizar tratamento com aerossóis, proficiência com o ventilador, conectar oxigênio e ambu no paciente gerenciamento de emergência, particularmente, quando chamar 911 ou buscar outros tipos de socorros emergenciais. (C24)

Nossos resultados suportam ou acreditam que o programa de treinamento está atingindo sua meta de preparar os cuidadores. Houve um aumento estatístico significativo nos escores dos testes dos cuidadores após o treinamento. É relevante que a performance dos cuidadores no teste pós-treino tenha sido semelhante à dos dez terapeutas respiratórios, o que sugere que os cuidadores conseguiram um alto nível de entendimento. (P17)

\section{VII - A oportunidade de desenvolver confianca e vínculo com seus cuidadores}

Os temas extraídos do documento P18 relacionam-se ao desenvolvimento de vínculo entre a criança e seu cuidador, durante um acampamento. Pelos dados, observa-se que a confiança é um processo que decorre do uso de estratégias favoráveis à interação. Entre aquelas utilizadas pelos profissionais que resultaram em relacionamento de confiança, estão: manter proximidade física, oferecer coisas próprias à idade e gênero, elogiar as realizações, priorizar e atender o desejo da criança. 
Entende-se que o processo iniciou-se com o atendimento das demandas físicas da criança e, no seu decorrer, foi reforçado pela previsibilidade e regularidade das atividades, tanto de lazer como de cuidado.

Em conseqüência, criança e cuidador puderam desprender-se das atividades já planejadas para realizar às de preferência pessoal, que exigiam maior entrosamento e conhecimento do outro. Em síntese, as experiências de cuidado favoreceram o estabelecimento da confiança e resultaram em melhor cuidado à criança. Merece destacar que o vínculo depende de um cuidador consistente, pois a cada inserção de um novo cuidador inicia-se um novo processo de confiança.

No presente estudo, confiar não foi meramente um atributo necessário para iniciar o relacionamento, mas foi adquirido como resultado do uso de estratégias de reforço durante os tipos de relacionamentos envolvidos. (P18)

A distância física aumentou quando o cuidador ficava na vertical ao lado do acampante, mas foi diminuída quando o cuidador se abaixou ao nível dos olhos do acampante, então, o par pôde falar e se olhar sem pressão. (P18)

Os cuidadores demonstraram respeito pelos desejos dos acampantes. Por exemplo, um acampante tinha sonhado ir nadar e tocar o fundo da piscina com seus dedos. Quando seu cuidador tornou-se consciente de seu desejo, nadar tornou-se uma prioridade a partir do primeiro dia. (P18)

Embora seja um modelo baseado na comunidade, estes achados sustentam claramente a importância de um cuidador consistente, como o fator mais importante influenciando a evolução em direção a um relacionamento de ligação. (P18) 


\subsection{Ações de promoção à saúde integral da criança dependente de tecnologia}

Este conjunto de dados agrupou ações implementadas ou recomendações dos autores para enfrentar os fatores desfavoráveis ao crescimento e desenvolvimento da criança ou adolescente dependente de ventilador, ou seja, qualquer ação que colabore ou assegure cuidado integral da saúde e que oportunize atendimento às necessidades essenciais das crianças, ajudando-as a se desenvolver. As medidas identificadas nos documentos analisados reportam-se aos diversos níveis de atenção, desde as ações realizadas por cuidadores familiares ou profissionais até a criação de políticas públicas e normas regulamentadoras para o atendimento dessas crianças.

\section{1 - Ações para enfrentar a falta de profissionais que atendam às necessidades de saúde da criança dependente de $\underline{\text { tecnologia }}$}

Reúne recomendações e ações para reduzir o impacto da escassez de profissionais disponíveis para o cuidado da criança dependente de ventilador, bem como, para melhorar a competência destes para o cuidado. Visam não só a melhorar a assistência a que as crianças são submetidas, sobretudo, a assistência de enfermagem, como também são ações que favorecem a saída do hospital, a transferência da unidade de cuidados intensivos para unidades de internação e o retorno da criança para casa.

Os documentos (C56, P17, P29, P34, P62, P103, P204, P207) recomendam que: enfermeiras especialistas treinem pessoas leigas para 0 cuidado domiciliar; que os pais sejam capacitados para assumir os cuidados da criança em casa, os profissionais alocados em enfermarias pediátricas sejam capacitados para fornecer cuidados seguros e atendimento de emergência e que os cursos de formação profissional forneçam diretrizes 
para o cuidado integral contemplando, assim, aspectos médicos, tecnológicos e de desenvolvimento infantil.

No documento C56, os dados obtidos afirmam que o suporte de enfermagem domiciliar pode ser fornecido por cuidadores menos qualificados, visto que foram competentes na execução de cuidados complexos e apresentaram menor rotatividade.

É a opinião deste autor que provedores de atendimento domiciliar não necessariamente precisam de um diploma de enfermagem, desde que sejam devidamente treinados pelo pessoal de enfermagem e pelos médicos. Tais medidas podem tornar-se necessárias para superar deficiências em recursos de enfermagem e, também, podem diminuir os custos do cuidado domiciliar. (P62)

Finalmente, com a perda de todas menos duas enfermeiras, as assistentes de cuidados passaram a gerenciar a maior parte das crianças em casa. Elas foram competentes, confiáveis, como também se mantiveram no posto por mais tempo que as enfermeiras registradas $e$ as famílias tinham um bom relacionamento com elas. (C56)

Por causa da complexidade das condições destas crianças e do suporte tecnológico que elas requerem, como também da falta de enfermeiras de home care por todo país, pais devem participar do cuidado médico domiciliar e monitoramento. Assim, o ensino e o treinamento extensivo dos cuidadores adultos devem ser concluídos previamente à alta da criança. (P17)

Do ponto de vista da aprendizagem compartilhada com cursos sobre cuidados intensivos pediátricos, embora haja claramente áreas de sobreposição de competências e de conhecimentos necessários, seria errôneo pensar que a competência exigida é idêntica. Assim, algumas áreas de aprendizagem compartilhada, como o suporte básico de vida e os princípios da ventilação 
assistida possam ser apropriados, há uma série de áreas temáticas que foram vistas como menos importantes. Pode haver um lugar para o ensino compartilhado, mas isso precisa ser bem planejado para que as necessidades específicas de todos os grupos de participantes sejam preenchidas. (P34)

\section{II - Acões para enfrentar a falta de servicos e melhorar a comunicacão nos diversos níveis de atenção}

As ações objetivam ampliar o acesso à assistência de saúde, a serviços e a ambientes coerentes com as necessidades da criança dependente de ventilador, bem como a integração entre os serviços de saúde domiciliar e hospitalar. As recomendações consistem em: organizar serviços de apoio na comunidade; organizar espaços de convivência onde o foco seja a criança; organizar serviços de assistência domiciliar e de substituição temporária de cuidados; admitir crianças estáveis em enfermarias pediátricas; aumentar o número de unidades de reabilitação, unidades de transição de cuidados e aumentar o número de leitos das já existentes. Estas medidas, além de atender à demanda crescente do número de crianças/adolescentes dependentes de ventilador, também favorecem a transferência da criança estável mantida em Unidade de Terapia Intensiva. (documentos C56, C72, C76, P18, P24, P29, P71, P103, P207)

Concluindo, crianças crônicas dependentes de ventilador podem ser hospitalizadas com sucesso e segurança em um ambiente hospitalar que não a unidade de cuidados intensivos (enfermaria pediátrica). Hospitalizações de crianças dependentes de ventilador medicamente estáveis não aumentam o risco de transferências inesperadas para a ICU nem aumentam o risco de morte, desde que a monitorização e os cuidados adequados sejam instituídos. (P207)

A unidade (unidade de transição de cuidados) destina-se a fornecer uma atmosfera caseira para incentivar o desenvolvimento 
psicossocial da criança. A filosofia da unidade favorece o desenvolvimento de uma rotina diária mais "normal" para a criança, que pode incluir visitas a berçários, freqüência à escola, saídas regulares e visitas a casas, proporcionando o máximo possível de normalidade e diversão para a criança, para ajudar na reabilitação e preparo para alta. Carrinhos de puxar e cadeiras de rodas são especialmente adaptados para acomodar móveis ventilatórios e equipamentos de emergência. (P71)

Planos para o gerenciamento de exacerbações agudas ou mudanças no status médico devem ser bem estabelecidos. Canais de comunicação entre o clínico geral, hospital local e centro de referência terciário precisam estar claros e com acesso aberto para facilitar a admissão hospitalar. P29

A meta dos organizadores do acampamento foi fornecer um ambiente que enfatizasse a saúde e o bem-estar, deslocando o foco do suporte tecnológico, esterilidade e das condições hospitalares para o foco da normalidade, enquanto oferecia cuidados seguros para os acampantes $O$ acampamento tinha muitos centros de atividades, tais como: uma quadra de basquete, haras, área de artesanato, piscinas, sala de jantar, alojamentos para acampantes e voluntários do acampamento (todas as instalações tinham acesso para pessoas com deficiência). Equipamentos extras e baterias de emergência estavam disponíveis e eram testados diariamente. (P18)

\section{III - Ações para assegurar recursos, regulamentacão e normas}

No âmbito da criação de normas e leis regulamentadoras para a organização social do cuidado das crianças dependentes de ventilador, surgem temas que indicam a necessidade de desenvolver políticas que considerem a visão dos pais e da criança dependente de ventilador; incentivar pesquisas para apoiar decisões em relação ao cuidado da criança; estabelecer normas que regulamentem o fornecimento de serviços essenciais, como energia elétrica, telefonia, entre outros e assegurar e 
destinar recursos públicos para a criação de serviços na comunidade, como por exemplo, serviços de assistência domiciliar, espaços de convivência e unidades de transição de cuidados. (documentos P28, C67, P1, P103, C77, P36, P78, C72)

Qualquer desenvolvimento em políticas do National Health Service ou provisão de serviços deve incluir a visão dos pais e se apropriado da criança (Popay \& Willians, 1994). Os resultados de um questionário investigativo sobre a experiência e as visões [percepção] dos pais são apresentados, como evidências da perspectiva do consumidor. (P28)

No Reino Unido, houve recentemente o desenvolvimento de um número de políticas com objetivo de melhorar os serviços fornecidos para jovens que são dependentes de ventilador, tais como o comissionamento de unidades de ventilação prolongada. Embora a unidade, inicialmente, tivesse dez leitos, em razão da constante demanda para serviços de reabilitação respiratória pediátrica, a unidade quase dobrou em tamanho durante o curso dos quatro primeiros anos de existência. (P67)

Existe uma necessidade para uma legislação apropriada, definindo o processo da ventilação domiciliar crônica pediátrica. Além disso, as famílias com baixo status socioeconômico em razão de desemprego ou famílias com outros membros portadores de deficiência apresentam alto risco para serem incapazes de cuidar da sua criança em casa, podem se beneficiar dos serviços comunitários de suporte organizados. (P78)

As famílias são servidas por um serviço de saúde estatal que é relativamente abrangente e generoso. Em Quebec, os centros comunitários locais de saúde (CLSC) provem cuidados primários para os pacientes nas suas comunidades. (P1) 


\section{IV - Ações que apóiam a família da criança}

O foco principal de tais ações é reduzir as conseqüências financeiras, psicológicas, físicas e sociais da ventilação domiciliar sobre a vida familiar $\mathrm{e}$ atender às necessidades dos pais que assumem a responsabilidade do cuidado em casa, fornecendo-lhes infra-estrutura, suporte profissional adequado e cuidadores substitutos que possibilitem períodos de descanso. Obter suporte profissional adequado propicia benefícios à criança e à família. Para os pais, é fonte de ajuda e apoio, embora percebam a perda da privacidade em casa. Para a criança, além dos cuidados implementados pelo profissional, ficam as vantagens de ter pais menos sobrecarregados. Quando não existem cuidadores substitutos, a internação da criança estável, para acompanhamento de saúde aparece como uma oportunidade de promover descanso aos pais. Outras medidas surgem apontando a necessidade de iniciar precocemente o processo de alta da criança, permitindo tempo para o preparo emocional dos pais; acompanhamento da saúde mental dos pais; orientação profissional para que os pais possam lidar com as mudanças ao longo da experiência de cuidar do filho em ventilação domiciliar; participação dos pais em grupos de apoio; suporte da equipe de saúde comunitária e para que crianças e familiares recebam atenção integral por meio de cuidado sistemático, integral e coerente. (documentos C71, C76, P13, P16, P20, P24, P28, P29, P62, P78, P115).

A maioria dos pais estava feliz com seus cuidadores domiciliares, embora alguns afirmassem que houve falta de privacidade e alguns considerassem estressante ter cuidadores em casa, especialmente, se eles permaneciam lá 24 horas por dia. Férias anuais e doença foram difíceis de cobrir, muitas vezes, com os pais preenchendo a ausência. P13

A substituição temporária de cuidados, seja na casa ou em um ambiente alternativo, pode fornecer assistência à família fatigada pelo isolamento, responsabilidade e o implacável cuidado da 
criança dependente de ventilador. Sendo necessária a revisão da substituição temporária de cuidados, conforme a criança cresce e a família muda. A substituição deveria ser na forma que os pais pedem, a família pode desejar pessoal para acompanhá-la no feriado e não pela substituição convencional na qual a criança é removida da família. Outros preferem instalações para cuidado ocasional. (P29)

O planejamento da alta precoce não só permite aos pais se prepararem emocionalmente e psicologicamente para as negociações e desafios ameaçadores diante deles, mas também Ihes traz com freqüência uma compreensão surpreendente: que a vida de sua família pode ser funcional e significativa apesar da deficiência crônica de seu filho/a. Nossa impressão é de que o planejamento de alta precoce é proativo, cria um estado de espírito nos pais, contribuindo para o sucesso. (P78)

Os achados deste estudo têm implicações para a prática de enfermagem. A natureza cíclica e contínua das lutas diárias, inerentes ao cuidado de uma criança com necessidades complexas, sugere a necessidade de avaliação contínua da família. Mesmo quando as famílias conseguem superar os problemas iniciais, elas podem precisar de ajuda no encaminhamento de questões em andamento, bem como orientação e suporte quando mudanças podem ser esperadas, tais como; a transição para a adolescência. (P115)

\section{$\underline{V}$ - Ações de apoio à criança enquanto vivencia experiências difíceis}

Agrupam-se as recomendações e as ações desenvolvidas para apoiar a criança dependente de ventilador que vive experiências difíceis, sobretudo no que se refere à hospitalização prolongada em unidades de cuidados intensivos. Além de transferir a criança estável para ambientes mais apropriados, que atendam suas necessidades de desenvolvimento, como as unidades de transição de cuidados, contempla ações que implicam a reavaliação da postura profissional e das concepções sobre quem é a 
criança em questão, ações que promovam sua saúde e desenvolvimento e ações de defesa da criança e de sua família, como o direito à educação.

São ações de promoção à saúde e desenvolvimento da criança/adolescente dependente de ventilador: capacitá-la para comunicar suas opiniões e percepções aos membros da equipe multiprofissional, compreender suas respostas e percepções, desenvolver autonomia, fornecer informações, reabilitação e atendimento psicológico, desenvolver estratégias que aproximem profissionais e crianças, como o lazer e manter laços criança-família. (documentos C42, C67, C71, C72, P36, P76, P146)

...as enfermeiras necessitam advogar por locais alternativos
apropriados em seus hospitais. Com estas alternativas, as
enfermeiras precisam reavaliar o tipo de cuidado que elas
oferecem à criança dependente de ventilador e à sua família
(Rennick 1995). Muitos dos aspectos negativos do cuidado (tais
como: apropriação da criança pelas enfermeiras e falta de
interesse dos médicos) poderiam ser evitados se a criança fosse
reabilitada e capacitada para voltar para casa muito mais cedo. (C67)

Crianças podem ser tranqüilizadas de que eventos e resultados não são de sua responsabilidade, mesmo se alguns eventos no passado são negativos ou complexos. Um acurado, apropriado e bem construído livro da história da vida e uma caixa de memórias contendo coisas de seu passado (como cartões de aniversários de pais e irmãos e bens preciosos) podem permitir à criança sentir que sua vida é valorizada por outras pessoas, e ela pode conseguir um sentimento de auto-estima. É absolutamente crucial que as enfermeiras de cuidados intensivos ajudem a criança a gravar suas experiências com desenhos, fotografias, narrativas e informações demográficas essenciais (como o aniversário dos irmãos e as informações de contato), a partir do início de sua admissão na unidade de cuidados intensivos e após esta. (C67) 
Se a criança for capaz, ela deverá aprender como direcionar seu cuidado, detalhes sobre sua condição médica, como reconhecer problemas e o que fazer sobre os mesmos. (C72)

\subsubsection{Potenciais de desenvolvimento efetivados versus potenciais de desenvolvimento comprometidos}

O potencial do ser humano decorre da interação entre as características herdadas e as experiências estabelecidas com as pessoas e objetos. A influência genética estabelece um potencial que pode ser atingido, mas o alcance desta meta depende das condições em que ocorrem o crescimento e o desenvolvimento. Os temas desta categoria fornecem dados sobre o que a criança/adolescente foi capaz de realizar, bem como revelam os prejuízos a que seu potencial foi submetido. Os contextos de cuidados parecem estar associados ao maior ou menor desenvolvimento do potencial das crianças e adolescentes. As subcategorias 1) Potencial efetivado: a competência da criança dependente de ventilador para desenvolver-se, conforme esperado e 2) Potencial comprometido: danos ao desenvolvimento I à vida da criança dependente de ventilador são apresentadas a seguir:

\subsubsection{Potencial efetivado: COMPetÊnCia da CRIANÇA DEPENDENTE DE VENTILADOR PARA DESENVOLVER-SE, CONFORME ESPERADO}

Esta subcategoria construiu-se apoiada na junção de temas que demonstram a competência da criança dependente de ventilador para agir em prol da satisfação das necessidades da infância e superar limitações inerentes às condições que vivencia. Entretanto, as ações estão atreladas à fase de desenvolvimento em que ela se encontra. A capacidade de desenvolver-se de maneira esperada para a idade associa-se ao potencial de cada indivíduo, assim como as condições facilitadoras que encontra. 
Desta forma, os temas que compõem esta subcategoria não apresentam somente o que a criança foi capaz de fazer, mas também refletem o contexto favorável a que foram submetidas. Esta subcategoria é composta pelas temáticas: 1 . A criança é competente para comunicar-se; 2 . A criança é competente para desenvolver confiança no cuidador e estabelecer relacionamentos seguros; 3. A criança é competente para socialização; 4 . A criança é competente para aprender.

Cabe ressaltar que os dados analisados limitaram-se a alguns aspectos do desenvolvimento, excluindo, por exemplo, o componente motor. Provavelmente, isto se deu, em razão da ênfase nos aspectos psicossociais do desenvolvimento infantil, nos textos que compuseram o corpus de análise deste estudo.

\subsection{A criança é competente para comunicar-se}

No documento P146, encontram-se evidências de que crianças dependentes de ventilador podem e querem se comunicar. Crianças e adolescentes desenvolveram formas alternativas de comunicação para partilhar suas histórias e opiniões e, assim, vencer as limitações impostas pela própria patologia, pelo uso da traqueostomia, como também pela falta de reabilitação.

Foram tiradas fotografias das condições ambientais e os jovens, voluntariamente, permitiram ao pesquisador acesso ao material adicional de apoio, tais como: fotografias e trabalhos escolares. Seis jovens utilizaram técnicas de comunicação por meio da fala, desenho e jogos (Mahon et al. 1996). Dois indivíduos necessitaram de um cuidador para ajudá-los a se comunicar, um jovem não tinha qualquer expressão ou método estabelecido de comunicação (pais liam o movimento do lábio superior) e outros sete tiveram alguma dificuldade na comunicação, tais como não ter uma válvula de fala para a sua traqueostomia. Quando 
capacitados para se comunicar, os jovens foram narradores competentes de suas histórias. Descobertas sobre o fenômeno de ser um jovem dependente de ventilador foram adquiridas por meio de uma série de técnicas. (P146)

\subsection{A criança é competente para desenvolver confiança no cuidador e estabelecer relacionamentos seguros}

Os temas revelam a competência e o empenho da criança para interagir e desenvolver relacionamentos de confiança. O documento P18 descreve as experiências entre crianças dependentes de ventilador e cuidadores de um acampamento que resultaram em vínculos afetivos. Tornou-se evidente que a confiança havia se estabelecido por meio da observação de comportamentos que representam intimidade, segurança e amizade, que foram as interações recíprocas freqüentes, incluindo toque e contato visual; comportamentos de proteção e lealdade; compartilhar idéias, negociações e escolhas; interesse genuíno no outro e permitir à criança maior independência.

Dentro desse contexto, a confiança no cuidador foi a base para a criança experimentar novos relacionamentos. Já o documento P76 traz evidências da formação de vínculos seguros entre criança e profissionais da equipe hospitalar.

O acampante e o cuidador atingiram a meta de tornarem-se ligados pelo aumento da familiaridade e construção do relacionamento de confiança. Tornar-se ligado foi evidente quando eles pareciam sincronizados ou demonstravam momentos de conhecimento e aceitação do que o outro estava pensando ou fazendo.

Conforme os cuidadores reconheciam os sinais não-verbais usados pelo acampante e iam se tornando mais familiares, antecipavam as necessidades do acampante, assim, o cuidador aprendia como o acampante respondia, agindo sem ser solicitado. 
Por exemplo, os cuidadores notavam quando os acampantes estavam cansados e sugeriam uma soneca antes da situação piorar. Tornar-se ligado foi evidente quando um poderia dizer para o outro, "Vamos jantar" ao invés de "Talvez eu pudesse levar você para jantar?".

A inclusão aumentada do outro como parceiro ilustrou a intensidade insular da díade durante as atividades no acampamento. Desse modo, a familiaridade aumentou e a proximidade e a facilidade mútuas puderam ser observadas nas atividades diárias. Por exemplo, durante os procedimentos terapêuticos, o acampante podia se apoiar no cuidador enquanto brincava com e deixava o cuidador prosseguir com o que precisava ser feito. A experiência do acampamento progrediu, os parceiros encontraram jeitos singulares para usar comportamentos mais próximos. Por exemplo, começaram a usar piadas que só os dois entendiam ou planejar surpresas, tais como ser o melhor vestido em um desfile. Estes planos secretos forneceram à díade uma identidade única que protegeu o relacionamento e excluiu estranhos. Tornar-se ligado, também, significou identificar-se e relacionar-se com o outro em diferentes grupos sem temer a perda da proximidade da parceria cuidador - acampante. (P18)

O hospital é uma casa longe de casa. Estas crianças têm profunda apreciação pela equipe e o hospital onde elas receberam seus cuidados. Seus comentários sugerem que este conforto não foi alguma coisa que está inerente, mas, pelo contrário, foi desenvolvido ao longo de anos de experiência. Um adolescente que está em transição para o cuidado adulto, referiu-se ao hospital como uma "casa longe de casa". Tal confiança em seus cuidadores permitiu a esta criança cronicamente doente atravessar o tempo negativo em sua vida e superar seus medos. Uma criança de seis anos de idade, com síndrome de hipoventilação central, que esteve os primeiros três anos de sua vida no hospital, referiu-se ao hospital como "seu hospital". Durante este estudo, ela celebrou seu sexto aniversário no hospital rodeada por enfermeiras e médicos, no lugar de crianças da sua própria idade. Este marco foi particularmente importante, 
porque foi seu primeiro aniversário com seu novo marcapasso diafragmático [diaphragmatic pacer] permitindo a ela correr livre para brincar de anfitriã com qualquer um que entrasse pela porta da unidade. (P76)

No relacionamento descrito como de ligação, a confiança desenvolveu-se para um grau no qual o acampante confiou no cuidador para estar ali quando necessário, facilitando o crescimento individual e a interação com as outras pessoas. (P18)

\subsection{A criança é competente para socialização}

Os dados referem-se ao desenvolvimento emocional e social da criança dependente de ventilador. Os documentos C76 e P76 fornecem evidências da capacidade da criança para fazer amigos, relacionar-se com seus pares e com seus irmãos. A esta capacidade, associa-se a oportunidade de viver com seus familiares e freqüentar espaços de convivência como a escola. O documento P76 registra o depoimento de escolares sobre o valor da amizade em suas vidas.

E acrescenta: "Desde que Amanda voltou para casa, o seu comportamento tem realmente melhorado. Quando ela estava no hospital, ela constantemente queria sua mãe, ela era o centro das atenções. Agora isto mudou e ela só quer brincar e ser como as outras crianças. Ela ama estar em casa com sua família". (C76)

Amizades foram importantes para a criança. Ansiosamente, eles recitaram a lista de amigos da escola e de pronto os reconheceram como sendo uma das coisas que os fazem mais felizes. (P76)

O relacionamento de Amanda com sua irmã, Lisa, de nove anos de idade, também se beneficiou com a ida para casa. Embora exista um ciúme esperado entre as duas meninas e competição para a atenção da mãe, Jeanette McGrogan diz que isto difere 
pouco dos irmãos que cresceram juntos desde o nascimento. (C76)

\subsection{A criança é competente para aprender}

Os documentos C76, P27, P59 e P76 fornecem dados sobre o desenvolvimento cognitivo. Há evidências de que crianças dependentes de ventilador têm sucesso escolar e engajam-se em atividades que demonstram sua capacidade intelectual.

A assiduidade escolar de Amanda também melhorou. Antes, ela tinha de contar com a disponibilidade do pessoal docente no hospital. Agora que ela recebe cuidado individual, raramente falta às aulas na Escola Especial Lancastrian em Didsbury. "Ela é brilhante", diz sua mãe. "A sua leitura está à frente de sua idade". (C76)

O principal indicador da qualidade de vida é a reintegração no sistema escolar. Múltiplos estudos demonstraram que as crianças dependentes de ventilador foram escolarizadas com sucesso durante anos. (P59)

As Atividades diárias da criança assistida por ventilador são: televisão, ouvir música, freqüentar a escola, lições de casa, atividades no computador, falar ao telefone, trabalhar. Atividades mensais da criança assistida por ventilador são: andar de carro, jogos de computador, comer fora, cinema, freqüentar eventos esportivos, jogos com cartões/ tabuleiros. (P27)

\subsubsection{POTENCIAL COMPROMETIDO: DANOS AO DESENVOLVIMENTOI À VIDA DA CRIANÇA DEPENDENTE DE VENTILADOR}

Os dados que pertencem a esta categoria, demonstram os danos e prejuízos, temporários ou permanentes, no desenvolvimento da criança dependente de ventilador e associam-se à exposição a cuidados e 
ambientes inapropriados. Este conjunto de dados foi construído pelas seguintes temáticas: 1. Sentimentos de desvalor, exclusão e isolamento; 2. Prejuízos à formação de vínculo entre pais e crianças; 3. Distúrbios físicos, comportamentais e de desenvolvimento; 4 . Morte.

\subsubsection{Sentimentos de desvalor, exclusão e isolamento.}

Durante a hospitalização prolongada, crianças e adolescentes são excluídos de seu meio e da convivência com sua família e amigos. Nos documentos C67, C76 e P146, crianças referem-se às conseqüências dos cuidados que receberam quando hospitalizadas e que resultaram em sentimentos de desvalor, exclusão e isolamento. Deixar de ser capaz de comunicar-se em sua língua materna, ser posto para adoção e não ter lembranças de seus pais e irmãos foram listadas como perdas resultantes da constante separação de suas famílias. Além da exclusão familiar, a distância com o grupo social de origem causou rupturas com a própria cultura, religião e identidade. Ficar no hospital, sem motivo para tal, foi percebido como algo que impossibilita viver a vida e a torna deficiente e sem valor.

O direito da criança para manter contato com membros de sua família de nascimento (salvo existência de circunstâncias excepcionais) é delineado na Convenção das Nações Unidas. Para três crianças,no presente estudo, um prolongado período de tempo em uma unidade de cuidados intensivos foi associado com a constante separação de suas famílias. Dois jovens foram finalmente transferidos para uma comunidade residencial para jovens deficientes, e a terceira está aguardando cuidados em um lar adotivo. (C67)

Em razão desse isolamento, o jovem nem sempre se sentiu uma parte valorizada da sociedade. Ele perdeu, além disso, contato vital com coisas, tais como: seu quarto, pertences, grupo cultural, 
educação religiosa, língua materna, irmãos, família extensa, animais de estimação, festas e feriados. (P146)

Jovens encontraram dificuldades para sair e encontrar amigos, enquanto passaram períodos longos de tempo no hospital. Um sentimento de estar no limbo e socialmente excluído foi muito proeminente em muitas conversas. Um jovem disse: "Eu sou deficiente, portanto, eu não sou normal, estou isolado do mundo real e não posso ser parte dele." (P146)

\subsection{2.2 Prejuízos à formação de vínculo entre pais e criança}

Nos documentos C67 e P28, há evidências do prejuízo à capacidade da criança formar vínculos com adultos significativos em decorrência do ambiente de cuidados durante a hospitalização prolongada.

Pais descreveram suas experiências negativas de tentar estabelecer uma ligação com seus bebês e enfrentar a separação prolongada. O rompimento da ligação maternal foi óbvio. Uma mãe explicou. "A ligação - nunca aconteceu". (C67)

Os pais da criança 7 expressaram preocupações significativas sobre o bem-estar de seu filho: "Ele acha que não pertence a ninguém ou a nenhum lugar. Ele é quase institucionalizado, uma vez que ele tem estado no hospital por muito tempo." (P28)

\subsection{Distúrbios físicos, comportamentais e de desenvolvimento}

Agrupam-se os temas que evidenciam os distúrbios físicos, comportamentais e de desenvolvimento exibidos por crianças e adolescentes submetidos à longa permanência hospitalar, à falta de informações, bem como ao controle excessivo por parte dos profissionais. Os comportamentos descritos nos documentos C67, C76, C42 e P28 são: 
automutilação, insegurança, timidez, evitar contato com outras crianças, recusar a receber alimentos, ir com estranhos e comportamentos violentos.

$\mathrm{Na}$ seqüência da operação, a criança freqüentemente parecia irritada e angustiada, muitas vezes cuspia, nas enfermeiras que cuidavam dela. Ela também exibiu comportamento de morder os lábios. (C42)

Crianças que não eram capacitadas para ter controle sobre suas próprias vidas desenvolveram um número de respostas comportamentais e biológicas. Por exemplo, muitos pais disseram que, mais tarde, na vida sua criança permaneceu insegura, desconfiava de pessoas e que não gostava de sair de casa. Outras disseram que seu filho somente queria estar com adultos e evitava contato com outras crianças. Muitos pais recordavam que seu filho ia com qualquer adulto, o que causava medo por sua segurança. Algumas das crianças recusavam comer alimentos e como resultado sofreram procedimentos cirúrgicos adicionais (como a inserção de um tubo de gastrostomia) para assegurar que sua ingesta nutricional fosse adequada. Pais recontaram como suas crianças tinham desenvolvido comportamentos destrutivos e estavam violentas; "Nenhum de nós pode controlá-lo. Ele não faz o que mandam, ele pede atenção, faz birra, ele joga uma cadeira pela sala". Pais, geralmente sentem que os problemas psicológicos e comportamentais de sua criança resultaram dos longos períodos de tempo gastos no hospital e do pouco controle sobre suas vidas. (C67)

Doze meses após, tanto Amanda como sua família são claras quanto às vantagens. A mãe de Amanda, Judith, afirma: "Quando ela entrou a primeira vez em casa nas visitas de Booth Hall, tudo que ela queria fazer era voltar para o hospital. (C76) 


\subsection{Morte}

O documento P28 refere-se à morte acidental de crianças em ventilação domiciliar como conseqüência da falta de supervisão.

Em uma coorte de cinqüenta e quatro crianças, dezessete mortes ocorreram, das quais dez foram súbitas e inesperadas (Frates et al., 1985). Três destas mortes foram causadas pela falta de observação da desconexão do ventilador e uma menina de 13 anos morreu à noite, após oito anos e meio em ventilação devido falha elétrica não observada por sua família que estava dormindo. Outros cinco pacientes morreram enquanto estavam conectados ao ventilador (ciclado a volume), todos tinham vias aéreas pérvias, mas a necropsia não foi realizada para determinar a causa da morte. Adicionalmente, uma criança morreu, após cair de sua cadeira de rodas que provocou hemorragia intracraniana. Em um amplo estudo de 101 crianças, seis pacientes morreram como resultado direto de acidentes com vias aéreas ou desconexão do ventilador, cinco destas mortes ocorreram em casa (Schreiner et al., 1987). Mais recentemente, Nelson et al., relatam, em um estudo longitudinal de 68 crianças dependentes de ventilador, que três crianças tinham morrido pelo mau funcionamento ou desconexão do ventilador. (P28) 


\section{DISCUSSÃO}

Os aspectos relacionados ao atendimento das necessidades de desenvolvimento da criança dependente de ventilador puderam ser identificados por meio da análise qualitativa dos documentos que compuseram a amostra desta pesquisa. Entretanto, cabe salientar as dificuldades encontradas no processo de identificação e seleção dos artigos.

A definição dos descritores para localizar os artigos relacionados ao tema proposto foi a etapa inicial do processo de busca bibliográfica. A ausência de descritor específico para dependência de ventilador configurouse como uma dificuldade. Assim, foi necessário identificar os descritores que melhor delimitassem as questões pertinentes ao desenvolvimento da criança com dependência de tecnologia ventilatória e usar palavras-chave como limitadoras.

A pesquisa bibliográfica se deu pelo cruzamento destes descritores entre si, como também, entre esses e as palavras-chave, o que resultou em um número expressivo de textos que precisaram ser selecionados e organizados em grupos temáticos, conforme descrito na metodologia. Contudo, não foi possível construir uma temática específica sobre o desenvolvimento da criança dependente de tecnologia. Isto demonstrou que o tema não vem sendo abordado como foco central nas pesquisas, apenas aparecendo de maneira fragmentada nos artigos localizados.

Outra dificuldade encontrada relacionou-se às estratégias usadas para organizar as referências em arquivos que facilitassem o gerenciamento das informações. Ainda que as planilhas tenham evitado duplicidade e possibilitado consulta às informações que identificaram os documentos, sua construção foi demorada e tomou tempo do pesquisador. 
Neste estudo, a tentativa de usar o programa End Note Web não foi bem sucedida, em razão das incoerências da própria ferramenta. Como o processo de busca já tinha sido iniciado, era necessário refazê-lo, importando as referências localizadas nas bases de dados por meio do programa e, mesmo que o levantamento tivesse sido refeito, o gerenciador não poderia acessar todas as bibliotecas.

Em relação aos dados que caracterizaram a amostra, percebeuse a prevalência de artigos escritos por enfermeiros, e isto pareceu relacionar-se com a proximidade entre os assuntos abordados nos documentos e a atuação desse profissional. Chama a atenção, a ausência de artigos latino-americanos, particularmente, do Brasil. As estratégias de busca, conforme descritas, permitiram localizar três artigos, porém estes não pertenciam aos grupos temáticos eleitos. Observou-se ainda uma constância do número de publicações no período delimitado do estudo.

No que tange à análise qualitativa, os agrupamentos temáticos levaram à construção de duas categorias principais que possibilitaram mapear, de forma ampla, os fatores que podem influenciar o desenvolvimento da criança dependente de ventilador, observando-se predomínio de fatores externos, ou seja, da maneira como o cuidado é organizado.

O desenvolvimento infantil é fortemente influenciado por fatores intrínsecos, entendidos como os atributos geneticamente determinados, como também, por fatores extrínsecos à criança, ou seja, pelo ambiente onde a criança vive e pelos cuidados que Ihe são dispensados (Brasil, 2002), sendo hoje amplamente conhecida a destacada importância do ambiente para a realização do potencial de desenvolvimento (Brazelton, Greenspan, 2002).

Conforme descrito nos resultados, a categoria "Concepções e práticas que resultam em cuidado desigual" revelou as oportunidades e desafios que a criança dependente de ventilador precisa enfrentar para 
realizar seus potenciais e desenvolver-se. Tanto oportunidades como desafios estão presentes em todos os cenários de atenção à saúde da criança e se estabelecem nas interações entre criança, ambiente e cuidador. Ao que parece, essas interações sofrem a influência das várias concepções sobre a criança e sobre a dependência de tecnologia ventilatória na infância, determinando contextos diversos e até opostos de cuidado que podem favorecer ou não o atendimento das necessidades essenciais.

Angelo e Veríssimo (1996, p. 89) afirmam que: "a conexão entre pensamentos, crenças e ações é inquestionável e as conseqüências são inúmeras possibilidades de agir e de ser, tendo em vista os infindáveis pensamentos que antecedem a ação".

Já que o desenvolvimento humano é dependente da interação entre indivíduos e ambientes e que a interação é produto de concepções e valores, pode-se dizer que as práticas de saúde, descritas na subcategoria "Contexto desfavorável ao desenvolvimento global da criança dependente de ventilador", podem pôr em risco o potencial de desenvolvimento dessas crianças.

Cabe destacar que não foi intenção desta pesquisa correlacionar os dados sobre os potenciais de desenvolvimento e os contextos a que as crianças foram submetidas, fossem eles desfavoráveis ou favoráveis, uma vez que não se tratou dos objetivos propostos e nem mesmo os documentos estudados possibilitaram estabelecer essa relação. Entretanto, pode-se dizer que o potencial revelado da criança dependente de ventilador sinaliza, tanto sua competência e resiliência como políticas e práticas voltadas a garantir atenção às necessidades essenciais.

Quando as condições favoráveis ao desenvolvimento são negadas, torna-se impossível conhecer o potencial da criança; os prejuízos instalados, muitas vezes, são irreparáveis. 
Pode-se compreender 0 efeito extremo da negligência às necessidades essenciais nas experiências de crianças vivendo em orfanatos na Romênia:

\begin{abstract}
Nestes ambientes, sem afeto ou interação social e intelectual adequadas, as crianças desenvolveram déficits físicos, intelectuais e sociais graves. Crianças de quatro ou cinco anos apenas conseguiam se comunicar com gestos simples, como apontar para a comida. Quando aborrecidas, com freqüência batiam ou, às vezes, mordiam freneticamente seus próprios braços. Eles não tinham linguagem ou capacidade para usar figuras para expressar necessidades ou desejos básicos, sem falar de comunicações mais rápidas, apenas capacidades fugazes de receber conforto ou simpatia quando magoadas ou aborrecidas. (Brazelton e Greenspan, 2002. p. 13).
\end{abstract}

Este relato assemelha-se ao da temática que discorreu sobre as evidências de danos ao desenvolvimento da criança dependente de ventilador, sobretudo às que viveram longos períodos de internação. Como as crianças do orfanato, elas foram excluídas de suas famílias e da sociedade, o que resultou em um sentimento de desvalor e baixa estima. Elas exibiram comportamentos violentos com seus cuidadores e pais, como também comportamentos de automutilação. Há relatos de distúrbios físicos e de desenvolvimento como: insegurança, timidez, evitar contato com outras crianças, recusa a alimentos e aceitar facilmente ir com estranhos.

Nos documentos, afirma-se que avanços vêm ocorrendo nos cuidados em comparação às décadas anteriores (Edwards, O'Toole, Wallis, 2004; Capen, Dedlow, 1998), evidenciando a crescente preocupação com o bem-estar da criança, manifestada em premissas anteriormente inexistentes, tais como: "viver no hospital é inadequado", "a ventilação domiciliar é segura e benéfica para a criança", "os cuidados domiciliares normalizam a vida e promovem o desenvolvimento infantil", "a comunidade deve se organizar 
para atender às demandas psicossociais da criança em ventilação domiciliar".

No entanto, os relatos da prática mostraram que a necessidade de proteção física, segurança e regulamentação foi marcadamente mais presente, caracterizando sua priorização em detrimento das demais, particularmente, as necessidades para o desenvolvimento. Isso demonstrou um descompasso entre a prática e os programas propostos para a atenção desse grupo. Pode-se dizer que os programas refletem conhecimentos de pesquisas que analisam desde os custos até a segurança dos diferentes tipos de atendimento, porém as práticas são determinadas também pelas concepções dos próprios trabalhadores envolvidos no cuidado.

Em relação à priorização da proteção física, ela correspondeu à hierarquização de necessidades, tal como postulado por Maslow (1970). Neste sentido, cabe refletir sobre o que apontam Veríssimo e Sigaud (1996, 2008). As autoras defendem que, no caso da criança, tal hierarquia não se confirma, uma vez que a sobrevivência da criança depende igualmente da nutrição biológica e da nutrição emocional. Esta afirmação é sustentada em estudos que evidenciam o impacto da ausência de vínculo afetivo, como causa de distúrbios graves que podem até levar à morte.

A seguir, discutem-se as categorias, subcategorias e temas segundo o referencial de necessidades essenciais da infância proposto por Brazelton e Greenspan (2002). As necessidades serão analisadas de acordo com a organização apresentada pelos autores.

\section{NECESSIDADE DE RELACIONAMENTOS SUSTENTADORES CONTÍNUOS}

Por meio da análise temática, foi possível conhecer experiências de crianças dependentes de ventilador vivendo em ambientes institucionais, 
longe de seus pais. A distância, conseqüência da hospitalização que pode iniciar-se no nascimento e durar toda a infância, dificulta a formação de vínculo parental, visto que este é construído nas situações cotidianas de cuidado. No hospital, principalmente nas unidades de cuidados intensivos, onde normalmente, estas crianças são internadas, as oportunidades de banhar, trocar, ninar, aconchegar e cantarolar para o filho são mínimas, conforme observado nos documentos, em público e controladas por outras pessoas. Faltam tempo, condições e espaço para construir, juntos, um relacionamento afetivo e consistente, o que se configura em risco à saúde física e emocional da criança dependente de ventilador. Isto fica evidente no trecho em que Brazelton e Greenspan (2002) defendem a importância desta necessidade à saúde de qualquer criança:

Interações sustentadoras, afetuosas, com bebês e crianças pequenas, por outro lado, ajudam o sistema nervoso central a crescer adequadamente. Escutar a voz, por exemplo, ajuda os bebês a aprenderem a distinguir sons e a desenvolver a linguagem. (...) Trocar gestos emocionais ajuda os bebês a aprenderem a perceber e responder a indícios emocionais e a formar um senso de self. Registros cerebrais de indivíduos mais velhos mostram que as experiências, que são de maneira adequada, emocionalmente motivadoras e interessantes, utilizam os centros de aprendizagem do cérebro diferentemente de experiências que são excessivamente ou pouco estimulante. Privação ou alteração de experiências necessárias pode produzir uma variedade de déficits. (...) Estresse emocional também está associado a alterações na fisiologia cerebral. (Brazelton, Greenspan, 2002, p.23)

Outro aspecto, a considerar, refere-se à parte do processo em que os pais desenvolvem laços emocionais com a criança. (Wong, 1999c). Nos textos analisados, há poucas evidências de ações empreendidas para que os pais façam ligação segura com seus filhos no período de hospitalização. Quando há prejuízo na ligação, ou ainda, esta não se estabelece, é possível que eles sejam incapazes de cuidar e amar sua 
criança. A este respeito, pode-se concluir que esta é mais uma condição de risco, que pode levar até ao abandono da criança, como foi relatado em um dos textos.

Adicionalmente, foi possível perceber que, durante o processo de alta do hospital para cuidados domiciliares, se espera muito dos pais. Os profissionais e instituições, particularmente as financiadoras do cuidado, esperam que eles levem seus filhos para casa nem sempre garantindo o apoio necessário. Fica como uma tarefa dos pais superarem por si a falta de organização e suporte. Isto se torna um risco ainda maior no caso deles não terem desenvolvido ligação segura com a criança. Embora este tema não tenha sido evidenciado nos textos, a falta deste vínculo pode levar a um cuidado inadequado ou insuficiente (Spitz, 1983).

Atender a necessidade da criança de estabelecer relacionamentos seguros não é só responsabilidade de seus pais, mas de qualquer adulto envolvido em seus cuidados (Rezende, 2008). Portanto, no caso da criança dependente de ventilador que vivencia a experiência de crescer no hospital, esta responsabilidade deveria ser compartilhada com os profissionais de saúde, em particular, com os enfermeiros e seus auxiliares, por serem os que se mantêm maiores períodos em contato com ela e realizam as funções do cuidado cotidiano. Assim, são estes os que têm mais oportunidades de criar tais vínculos com a criança.

Ainda que na atualidade esta necessidade seja amplamente reconhecida nos textos de enfermagem em geral, conforme já mencionado, os dados revelam que pouco tem sido feito para atendê-la. Isto é ainda mais verdadeiro no contexto do ambiente de cuidados intensivos pediátricos, como exposto abaixo.

O espaço físico destas unidades foi reconhecido nos textos como inadequado para a realização de inúmeras atividades que possibilitariam o desenvolvimento pleno da criança, limitando a aquisição de competências e habilidades de diversas áreas, tais como: a motora, a social e a emocional. 
Embora ele seja inadequado para qualquer indivíduo clinicamente estável, em qualquer fase da vida, ele em si não justifica a privação aos estímulos necessários para o desenvolvimento emocional, sobretudo no que se refere ao desenvolvimento de apego com os adultos responsáveis por seus cuidados. A maneira como o cuidado de enfermagem é organizado nesses ambientes, é que impõe maior risco ao potencial da criança para estabelecer relacionamentos confiáveis e seguros.

$\mathrm{Na}$ maioria das vezes, os profissionais ocupam-se dos cuidados físicos e emergenciais e das rotinas implantadas para manter a ordem e interesses organizacionais e os financeiros da instituição. Alguns profissionais acreditam que podem fazer além. Outros que suas atribuições restringem-se a essas. Assim, as respostas às demandas da criança por atenção e interação tornam-se infreqüentes e insensíveis, e ela é privada de estímulos necessários para confiar em seu cuidador.

Essa abordagem do cuidado sustenta-se também na concepção sobre a criança e, especificamente, a dependente de ventilador. Quando a abordagem foca a criança e suas necessidades, a criança assimila a hospitalização como algo positivo, forma vínculos seguros com os profissionais da equipe e desenvolve uma percepção melhor de si e do ventilador, como nas descritas por crianças que referem que o hospital é "uma casa longe de casa" (documento P76)

A questão do vínculo quando a criança é cuidada em casa apareceu vagamente nos textos. Em relação à família, ficou subentendido que o fato da criança estar em casa por si promove essa interação. Há maior número de referências às barreiras de vínculo com os profissionais, destacando que quando os cuidadores domiciliares reproduzem a organização e o foco dos cuidados intensivos, as necessidades essenciais, entre elas, a de relacionamentos sustentadores contínuos, também não são asseguradas. 
$\mathrm{Na}$ análise temática, foram abordados vários fatores que contribuem para a inadequação nos cuidados domiciliares. Entre os que estão diretamente envolvidos com o déficit de atenção aos relacionamentos sustentadores contínuos no domicílio, estão: a) a escassez de enfermeiras e a falta de interesse deste profissional no trabalho com crianças dependentes de ventilador que são assistidas em casa; b) o enfoque tecnicista dado à formação dos cuidadores.

O primeiro, estimula a rotatividade dos profissionais encarregados de cuidar da criança. O segundo fator contribui para formação de profissionais menos preparados para lidar com as situações do desenvolvimento, como por exemplo, implementar ações para estabelecer confiança e vínculo.

Finalizando, vale ressaltar o empenho compartilhado de cuidadores, pais e crianças que resultou na formação de vínculos afetivos, conforme demonstrado na temática "a oportunidade de desenvolver confiança e vínculo com seus cuidadores", e corrobora sua importância tanto para a criança como para os profissionais.

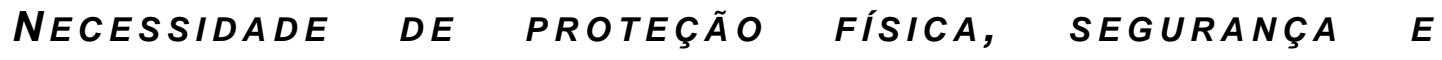
REGULAMENTAÇÃO

O processo de busca bibliográfica identificou quatro artigos que tratavam diretamente da temática proteção e segurança; no entanto, somente um atendeu aos critérios descritos na metodologia. Ainda assim, o tema foi, freqüentemente, discutido nos artigos analisados, em especial, no grupo temático "Processo de transição do hospital para casa".

A análise revelou a preocupação constante dos profissionais de saúde com a segurança física da criança. Isto pôde ser percebido pelas referências a pesquisas que comprovaram a eficiência e segurança da ventilação domiciliar, ou ainda, pelas ações implementadas durante a hospitalização da criança, entre elas, o treinamento dos pais. 
Em relação ao aspecto da segurança do uso do ventilador no domicílio, os textos apontaram que está amplamente confirmado, como se verifica no tema "Oportunidade de receber ventilação domiciliar segura e eficiente".

Quanto ao processo de treinamento dos cuidadores, na maioria das vezes, os pais, ele antecede a transferência para o domicílio. Durante esse processo, os pais aprendem a manusear o ventilador e desenvolvem cuidados complexos, como por exemplo, aspiração das vias aéreas. Eles são constantemente avaliados até se tornarem competentes para gerenciar as demandas de cuidado em casa.

O treinamento dos pais é uma ação profissional que promove o desenvolvimento da criança dependente de ventilador, já que colabora para que ela seja cuidada em casa por pais capacitados para atendê-la com segurança, conforme foi comprovado nos resultados obtidos.

Vários protocolos de treinamento e suas diretrizes estão descritos nos documentos lidos e revelam o empenho dos profissionais de saúde e pesquisadores para estabelecer normas com a finalidade de proteger a criança.

Ainda que o atendimento da necessidade de proteção física, segurança e regulamentações seja um pilar para o desenvolvimento saudável de qualquer criança, a preocupação excessiva dos profissionais com os riscos que envolvem o cuidado da criança dependente de ventilador funciona como uma barreira ao desenvolvimento quando limita ou, até mesmo, impede a convivência familiar, a socialização e a independência.

Ações como julgar que a criança estará mais segura no hospital do que em casa, podem ser consideradas como preocupação excessiva, situação essa exemplificada por pais que tiveram de se contrapor a esse julgamento a fim de poder levar seus filhos para casa. 
Aqui se evidenciou que a segurança física sobrepôs-se às demais necessidades essenciais da infância em certas práticas de cuidado estabelecidas no cenário de atenção à saúde. A visão de que a necessidade de tecnologia ventilatória torna a criança mais vulnerável e dependente do que qualquer outra criança, não só permeia as ações estabelecidas para manter a vida em segurança, como se torna a justificativa principal para as demais decisões sobre o cuidado.

NecEssidade de experiências Que RESPEITEM AS DIFERENÇAS INDIVIDUAIS

As experiências que respeitam as diferenças individuais constituem-se em oportunidades para que o cuidador conheça a criança e a forma que ela estabelece para lidar com o mundo, bem como para que a criança supere suas dificuldades e fortaleça suas capacidades (Brazelton, Greenspan, 2002).

No que tange aos cuidados que respeitam as particularidades da criança dependente de ventilador, duas situações merecem ser discutidas.

A primeira, refere-se às estratégias de comunicação implementadas para que as crianças pudessem participar das pesquisas e revelar seus pontos de vista, experiências e necessidades. Mesmo aquelas com alto grau de dificuldade para comunicar-se verbalmente foram incluídas e "ouvidas", contribuindo ativamente para ampliar o conhecimento sobre suas experiências.

A segunda situação retrata o empenho dos organizadores e profissionais do acampamento para garantir atenção às diferenças particulares destas crianças. A meta do serviço foi criar um espaço de convivência, socialização e autonomia para o cuidado.

Instalações e equipamentos foram organizados, tais como: acessos para pessoas com deficiência e baterias extras, para permitir a 
mobilidade. Antes do início do acampamento, os cuidadores fizeram contato com a criança e sua família para aprender as preferências e necessidades de cuidados dos acampantes.

Durante os dias que ficaram juntos, as estratégias usadas permitiram a realização de atividades que exigiam maior entrosamento e conhecimento do outro, o que promoveu a confiança entre criança e seu cuidador.

O sucesso obtido com essa experiência, detalhado em vários tópicos do tema "Oportunidades que ajudam as crianças dependentes de ventilador a perceberem seus potenciais", é um bom exemplo de que atender bem a criança demanda levar em conta suas peculiaridades, bem como, os aspectos esperados para a fase de desenvolvimento em que se encontra.

Assim como há uma priorização da segurança física, outras ações dirigidas a estas crianças priorizam seu estado clínico e o ponto de vista do profissional, como se observa em várias situações de decisão sobre o local de permanência e formas de cuidados. O que é permitido à criança depende menos de suas capacidades do que da percepção dos profissionais a respeito destas. Isso apontou para uma dificuldade de particularizar 0 atendimento, negligenciando esta necessidade.

NECESSIDADE DE EXPERIÊNCIAS ADEQUADAS AO DESENVOLVIMENTO

O estágio de desenvolvimento da criança determina quais experiências são necessárias para que ela adquira as habilidades inerentes à etapa vivida. O sucesso de um determinado estágio fornece o arsenal para a criança envolver-se em experiências cada vez mais sofisticadas e vencer os próximos desafios (Brazelton, Greenspan, 2002). 
Embora as tarefas sejam as mesmas para qualquer criança, é fundamental considerar as capacidades e vulnerabilidades individuais, como justificado no tópico anterior. Por exemplo, algumas necessitam de mais experiências para aprender a se relacionar com afeto e segurança, outras para se envolver em brincadeiras imaginativas.

A análise permitiu conhecer tanto as experiências que se configuram como adequadas, como aquelas que são desfavoráveis ao desenvolvimento da criança dependente de ventilador.

A impossibilidade de estabelecer relação entre crianças, faixa etária e experiências, mediante a análise dos textos, dificultou que os dados fossem apresentados e discutidos especificamente segundo os estágios de desenvolvimento, bem como particularizando efeitos negativos a esse processo. Contudo, tendo por base os conhecimentos já estabelecidos sobre desenvolvimento infantil e os dados dos textos foi possível fazer algumas associações.

As experiências adequadas foram: oportunidade de desenvolver confiança e vínculo, oportunidade de participar de atividades lúdicas e de lazer, oportunidade de freqüentar a escola, oportunidade de desenvolver autonomia para o próprio cuidado e oportunidade de viver em ambiente menos restritivo.

Ao que parece, tais experiências adequadas possibilitaram às crianças vencer limitações e desenvolver habilidades cognitivas, sociais e emocionais. Elas desenvolveram confiança e estabeleceram relacionamentos seguros, demonstraram capacidade intelectual, engajaramse em relacionamentos com seus pares e foram capazes de expressar suas opiniões.

Por outro lado, as barreiras à formação de vínculo, não ser respeitado, não ser compreendido e viver em ambientes restritivos, monótonos e solitários retrataram as experiências desfavoráveis relatadas 
por pais, profissionais e crianças, que, quando somadas, provavelmente tenham sido responsáveis pelos danos ao desenvolvimento infantis, já descritos.

Grande parte das experiências desfavoráveis associam-se a um tempo desnecessário de hospitalização que as impede de viver como crianças. Dentre outras, a experiência de escolarização é fundamental para o desenvolvimento infantil, especialmente, para o escolar e o adolescente. Por esta razão, Cejer (2007) ressalta que as oportunidades de se engajar em atividades e freqüentar a escola devem integrar o plano de cuidados da criança dependente de ventilador e não se constituir em concessão por parte da equipe hospitalar.

Para que as necessidades educacionais da criança dependente de ventilador possam efetivamente ser atendidas na comunidade, cabe refletir sobre o trabalho com pessoas com necessidades especiais nas escolas. Sekkel (2005) defende a necessidade de um ambiente inclusivo, "no qual as necessidades de cada um possam ser reconhecidas e legitimadas", para superar as barreiras que impedem a participação, a identificação e a compaixão. A autora conta sobre como a participação de crianças com necessidades especiais, na creche, despertou sentimentos intensos entre funcionários, educadores e familiares. Esses sentimentos variaram da compaixão ao medo, impedindo os relacionamentos e foram superados nas possibilidades de reconhecê-los para si mesmo, em um primeiro momento e, após, nas oportunidades de troca de experiências entre todos os que participaram do processo.

\section{NECESSIDADE DO ESTABELECIMENTO DE LIMITES, ORGANIZAÇÃO E EXPECTATIVAS}

As ações de estabelecimento de limites, organização e expectativas são fundamentais, para que crianças e adolescentes aprendam a conviver em sociedade. Quando os limites são transmitidos de forma empática e sustentadora, promovem o desejo de aprovação da criança e o 
respeito por aqueles que ama. Já, quando a disciplina impõe medo, as crianças sofrem prejuízos na auto-estima e na capacidade de tomar decisões adequadas e se responsabilizar por elas. Ressalta-se a importância de que os limites sejam empregados somente aos comportamentos indesejados da criança. (Brazelton e Greenspan, 2002)

Nos documentos analisados, não há relatos que subsidiem a discussão dos padrões adotados por pais e cuidadores para estabelecer disciplina.

No entanto, uma pesquisa desenvolvida para compreender as percepções sobre 0 ato de criar filhos dependentes de tecnologia revelou que a disciplina é uma área de conflito de opiniões entre pais e enfermeiras. Enquanto a maioria dos pais percebe que todos os filhos devem ser disciplinados da mesma maneira, as enfermeiras observam que os pais têm expectativas e ações diferentes quando comparados ao cuidado dos outros filhos. Outro conflito diz respeito a ser responsabilidade da enfermeira ou não realizar ações disciplinares. Um terço das enfermeiras que participaram do estudo sente que a questão disciplinar nem é um assunto pertinente no processo de criação da criança dependente de tecnologia, uma vez que em função de sua condição sequer seriam capazes de comportamentos inadequados (O'Brien, Wegner, 2002). Aqui se evidenciam idéias que compõem a concepção sobre estas crianças, que as colocam como essencialmente diferentes.

Em um documento analisado, pôde-se perceber que os limites impostos por profissionais nem sempre são empregados a comportamentos indesejados, como no caso das crianças que foram impedidas de usar cadeiras de rodas elétricas dentro e fora do espaço da UTI. É perfeitamente esperado que crianças queiram experimentar ambientes e objetos; no entanto, a autora que relata essa situação entende que as enfermeiras possivelmente enfrentaram o comportamento de exploração como um embate de forças, que resultou em conflitos com pais e crianças. 
Veríssimo et al (2008) advogam que um cuidador com conhecimentos sobre desenvolvimento infantil possui maior capacidade de distinguir comportamentos indesejados dos que são inerentes aos estágios de desenvolvimento. As expectativas de pais e profissionais norteiam as ações implementadas para prover disciplina às crianças que necessitam de algum tipo de tecnologia médica e cuidados especializados. Inconsistências nas práticas entre pais e enfermeiras domiciliares podem confundir a criança quanto ao que é esperado delas.

Brazelton e Greenspan afirmam que :

No centro de uma abordagem de ensino à disciplina, estão as expectativas. Os pais esperam que os filhos aprendam na escola, sejam membros de uma comunidade, preocupem-se com outras pessoas e sejam empáticos. Ao mesmo tempo, esperamos que as crianças lutem por objetivos que serão seus. Esperamos que elas se sintam realizadas por atingir objetivos que são importantes para elas, em vez de apenas cumprir uma agenda de seus pais. (Brazelton, Greenspan, 2002, p. 152)

Nesse sentido, a análise permitiu conhecer concepções sobre dependência de ventilação na infância que, provavelmente, modulem as expectativas das pessoas envolvidas, como também a auto percepção da criança. Se as concepções forem positivas (como qualquer criança, capaz, importante) a criança ver-se-á como igual.

Por outro lado, se as concepções forem negativas (um fardo, sempre criança, vulnerável e incapaz), as ações dos cuidadores poderão impedi-las de construir uma boa imagem de si mesmas ou até de internalizar padrões de comportamentos aceitáveis, como exemplificado no trecho destacado a seguir, que compõe a subcategoria "Distúrbios físicos, comportamentais e de desenvolvimento". 


\begin{abstract}
Pais contaram como suas crianças tinham desenvolvido comportamentos destrutivos e estavam violentas, "Nenhum de nós pode controlá-lo. Ele não faz o que mandam, ele pede atenção, faz birra, ele joga uma cadeira pela sala". Pais, geralmente, sentem que os problemas psicológicos e comportamentais de sua criança resultaram dos longos períodos de tempo gastos no hospital e do pouco controle sobre suas vidas. (documento C67)
\end{abstract}

\title{
NECESSIDADE DE CONTINUIDADE CULTURAL
}

Exemplos de crianças e jovens que viveram isolados de suas famílias e comunidades permearam os resultados deste estudo. Durante os anos que passaram em unidades de cuidados intensivos, eles foram privados de se relacionarem com pessoas do grupo de origem e, conseqüentemente de oportunidades para desenvolver pertença familiar e comunitária.

Os dados presentes na temática "Sentimentos de desvalor, exclusão e isolamento" revelam os danos causados à criança, assim como a suas famílias e comunidades. A ruptura com a família de origem foi marcada, tanto pelo abandono da criança no hospital como pela perda de alguma característica cultural comum à família, como: língua, religião ou etnia. Os adolescentes também foram excluídos da convivência com os grupos de amigos e impedidos de desenvolver identidade com seus pares.

Nestes casos, percebeu-se que a necessidade de continuidade cultural não foi assegurada por profissionais de saúde, suas instituições ou pelo sistema como um todo e, isto despertou nas crianças e adolescentes sentimentos de falta de valor e baixa auto-estima.

Um único artigo reuniu recomendações específicas para ajudar a criança que sofreu ruptura familiar conhecer sua história de vida, como: ajudar a criança organizar uma caixa de lembrança com fotos e pertences. 
O cuidado domiciliar representa uma oportunidade para a criança crescer e estabelecer relações com seus familiares, vizinhos e demais pessoas da comunidade. A casa é repleta de sinais que formam a identidade cultural da criança, conforme descrição feita no documento C67.

Os conflitos entre pais e cuidadores domiciliares, abordados neste estudo para caracterizar a formação profissional tecnicista, parecem sinalizar a dificuldade do profissional para aceitar os padrões familiares estabelecidos para criar e educar os filhos. No entanto, os temas relacionados aos aspectos que tratam da experiência da família não serão apresentados neste estudo.

NECESSIDADE DE COMUNIDADES ESTÁVEIS E AMPARADORAS

A necessidade de comunidades estáveis e amparadoras dá condições para que as demais necessidades sejam efetivamente implantadas, pois trata-se do compromisso governamental e das instituições implementá-las, fornecendo, assim, estrutura para que as crianças desenvolvam-se plenamente (Brazelton, Greenspan, 2002).

A evidente escassez de artigos publicados na América Latina sugere que o foco dos pesquisadores da região é desenvolver conhecimentos que incrementem a capacidade para resolver questões básicas de saúde. No Brasil, são notórios os esforços governamentais para promover políticas públicas e programas que busquem oferecer atendimento médico mais humano e de melhor qualidade para as crianças; no entanto, o principal objetivo das ações ainda é reduzir os índices de mortalidade infantil (Brasil, 2005; Druker, 2007). Cabe destacar, contudo, que já foram incluídos na política nacional temas relativos à criança com deficiência, o que indica um início de direcionamento para este grupo populacional.

Por outro lado, o fato da totalidade dos artigos analisados serem originados em países desenvolvidos sinaliza maior interesse na discussão dos problemas que envolvem os cuidados da criança dependente de 
ventilador, provavelmente, pelo fato de estarem vivenciando-os há mais tempo, uma vez que estas práticas já são mais usuais, ressalvadas as particularidades de cada país.

O atendimento das necessidades de saúde da criança dependente de ventilador variou amplamente nas regiões dos países onde os artigos foram publicados, como exemplificado na categoria "Concepções e práticas que resultam em cuidado desigual", evidenciando que mesmo nos países ricos o atendimento das necessidades essenciais não foi garantido a todas as crianças. Como exemplo, a subcategoria "Estrutura e suporte social inadequados" apresenta uma série de problemas que poderiam ser evitados se houvesse empenho governamental para resolvê-los, entre eles, a falta de recursos financeiros e de legislação que regulamentasse as ações em todos os níveis de atenção à criança.

Ao que parece isto reflete a concepção de que a criança dependente de ventilador é um "fardo" para os orçamentos das agências financiadoras, sejam elas oficiais ou privadas, o que coloca adversidades maiores, além daquelas associadas aos fatores biológicos.

Neste sentido, Petersen e Alexander (2001) entendem que as populações mais vulneráveis, como as crianças com necessidades especiais, são particularmente susceptíveis a políticas, programas e instituições que nem sempre estão preparadas para acomodar suas necessidades particulares. Os autores, ainda, chamam a atenção para a responsabilidade que a saúde pública tem com essas populações.

Rezende (2008) defende que "cuidar adequadamente não é somente uma questão de riqueza", mas sim de conhecimento e atitude quando a escolha é feita em favor da promoção do ser humano. 


\section{Considerações Finais}

A motivação para esta pesquisa surge de minhas inquietações, ao perceber, que as crianças dependentes de ventilador sob meus cuidados tinham menos oportunidades para satisfazer suas necessidades emocionais, sociais e intelectuais, em especial, aquelas que viviam no ambiente de cuidados intensivos. Assim, o que me moveu para esta busca, foi o desejo de descobrir caminhos que ajudassem ampliar as possibilidades de cuidado para que elas pudessem desenvolver todo seu potencial.

O presente estudo não teve a intenção de aprofundar as discussões a respeito de como as limitações físico-funcionais associadas à dependência de ventilador marcam o potencial de desenvolvimento infantil. Apenas pretendi colocar em foco a criança como pessoa em formação, com o intuito de sensibilizar o leitor para as questões relacionadas ao desenvolvimento humano enquanto processo fortemente influenciado pela forma que se é cuidado.

A opção por uma pesquisa bibliográfica deu-se por vários motivos, entre eles, a necessidade de reconhecer o que já está publicado sobre o tema, quais as questões mais discutidas pelos pesquisadores e profissionais e, assim, poder identificar as lacunas existentes de conhecimento das necessidades de desenvolvimento dessa população. A pesquisa bibliográfica permitiu possibilitou mapear os fatores que podem influenciar 0 desenvolvimento da criança dependente de ventilador, observando-se o predomínio de fatores externos, ou seja, da maneira como o cuidado é organizado.

A busca bibliográfica esbarrou em diversas dificuldades, como falta de descritores específicos para o tema que levou a uma estratégia de busca ampliada na maioria das bases de dados utilizadas. O grande número de documentos levantados exigiu que fossem estabelecidas formas de seleção e escolha dos textos usados na construção dos resultados. 
Desta forma, textos que poderiam ter contribuído para compreensão do tema, podem ter sido eliminados ou nem terem sido identificados, por não terem sido indexados considerando-se como foco os aspectos estabelecidos na busca, o que se configura como uma limitação do estudo. Textos abordando o tema talvez sejam encontrados em bases não indexadas, estes não puderam compor a amostra, o que pode ser entendido como outra limitação da pesquisa.

Além disto, é possível que as práticas de atenção a essas crianças em nosso País ainda não estejam divulgadas apropriadamente, por isso não tenham sido localizados textos nacionais sobre o tema, o que aponta para a necessidade de desenvolver pesquisas para mapeá-las.

Ainda assim, entendo que os objetivos foram alcançados, pois foi possível conhecer as oportunidades e desafios presentes no cotidiano da criança dependente de ventilador. Por meio desta pesquisa, refletiu-se sobre o que tem sido feito para assegurar atenção às necessidades de desenvolvimento, bem como, sobre as situações desfavoráveis que colocam em risco o potencial dessas crianças, podendo até mesmo causar-Ihes prejuízos irreparáveis.

Como foi possível perceber, as situações prejudiciais estão disseminadas nos muitos cenários de atenção à saúde, violentando os princípios bioéticos do cuidado.

O princípio da Autonomia afirma que os indivíduos capacitados para deliberarem sobre suas escolhas pessoais devem ser tratados com respeito pela sua capacidade de decisão. Este foi explicitamente negado em situações nas quais as crianças não foram ouvidas e nem consultadas sobre assuntos que afetam diretamente suas vidas. Isto foi ainda mais grave em circunstâncias em que mesmo a opinião e o desejo dos pais, os responsáveis legais pelas crianças, foram reconhecidos. 
Algumas práticas de cuidados estabelecidas impedem 0 desenvolvimento pleno da criança dependente de ventilador, causando-lhe prejuízos e danos. Ainda que as práticas sejam mantidas no intuito de garantir segurança, elas ferem o compromisso ético profissional com os princípios da beneficência e da não maleficência. Manter a criança restrita, isolada de seus pares, em condições inadequadas e, por que não dizer, iatrogênicas, são exemplos de prática que infringem os direitos da criança.

A condição de dependência da ventilação coloca a criança em situação de maior vulnerabilidade do ponto de vista orgânico e de sobrevivência, mas, quando seu cuidado considera prioritariamente esse aspecto, leva a outras causas de vulnerabilidade, em razão da limitação de suas oportunidades de desenvolvimento. Dessa forma, tais cuidados não podem ser considerados como os melhores (beneficência) nem como os não causadores de dano (não maleficência).

Quando questões financeiras e de recursos materiais e humanos são consideradas no cuidado dessas crianças, percebe-se que as escolhas de estratégias e de recursos destinados tendem sempre aos de menor custo, mesmo quando estes não sejam os que representem a melhor para elas, ou seja, nem sempre a escolha é feita considerando os que elas de fato necessitam, mas sim o que é mais barato e acessível aos financiadores do cuidado. Neste aspecto as questões de justiça e eqüidade também são infringidas, uma vez que as políticas de atenção à saúde deveriam ter como foco a melhoria da atenção a esse grupo, visivelmente em situação de vulnerabilidade. Melhorar a atenção significa para além de lhes garantir acesso aos recursos tecnológicos de sobrevivência, garantir-Ihes uma vida digna.

Considero que esta pesquisa possibilitou identificar pontos críticos nas formas de cuidar dos profissionais de saúde que afetam o desenvolvimento social e emocional da criança dependente de ventilador. Identificá-los e reconhecê-los configura-se como contribuição aos 
profissionais de enfermagem, uma vez que estimula o debate sobre o que tem sido feito e o que se pode fazer para transformar a prática assistencial.

Assim, acredito que este trabalho possa contribuir na formação de profissionais de enfermagem mais atentos as necessidades integrais dessas crianças, à medida que clarifica e suscita a reflexão sobre a influência dos cuidados de enfermagem em seu desenvolvimento.

Espero que o trabalho desperte uma reflexão profunda na forma de agir e pensar, a fim de contribuir para a construção de novos olhares e para a elaboração de estratégias que visem a promover o desenvolvimento integral da criança dependente de ventilador. 


\section{REFERÊNCIAS}

Adams $A B$, Shapiro R, Marini JJ. Changing prevalence of chronically ventilator-assisted individuals in Minnesota: increases, characteristics, and the use of noninvasive ventilation. Respir Care. 1998;43(8):643-8.

Ângelo $M$, Veríssimo MLOR. O papel da enfermeira centrado na criança e na família. In: Sigaud CHS, Veríssimo MLOR, organizadores. Enfermagem pediátrica: o cuidado de enfermagem à criança e ao adolescente. São Paulo: EPU; 1996. p. 89-96.

Bardin L. Análise de conteúdo. Rio de Janeiro: Edições 70; 1977.

Brasil. Ministério da Saúde. Portaria GM $n^{\circ}$ 1.531, de 4 de setembro de 2001. Garante o uso de ventilação não invasiva aos portadores de distrofia muscular progressiva [legislação na internet]. Brasília; 2001 [citado 2008 mar. 6]. Disponível em: http://portal.saude.gov.br/portal/sas/sapd/visualizar_texto.cfm?idtxt=22731.

Brasil. Ministério da Saúde. Agência Nacional de Vigilância Sanitária (ANVISA). Resolução $n^{0} 11$, de 26 de janeiro de 2006. Dispõe sobre o regulamento técnico de funcionamento de serviços que prestam atenção domiciliar [legislação na internet]. Brasília; 2006a [citado 2006 dez. 19]. Disponível em: http://elegis.anvisa.gov.br/leisref/public/showAct.php?id=20642\&word.

Brasil. Ministério da Saúde. Agenda de compromissos para a saúde integral da criança e redução da mortalidade infantil. Brasília; 2005.

Brasil. Ministério da Saúde. Saúde da criança: acompanhamento do crescimento e desenvolvimento infantil. Brasília; 2002.

Brasil. Ministério da Saúde. Secretaria de Atenção à Saúde. Cadastro nacional de estabelecimentos de saúde (CNES). Disponibiliza informações das atuais condições de infra-estrutura de funcionamento dos estabelecimentos de saúde [base de dados na internet]. Brasília; 2006b [citado 2006 dez. 19]. Disponível em: http://cnes.datasus.gov.br/.

Brazelton TB, Greenspan SI. As necessidades essenciais das crianças: o que toda criança precisa para crescer, aprender e se desenvolver. Porto Alegre: Artmed; 2002.

Capen C, Dedlow E. Discharging ventilator-dependent children: a continuing challenge. J Pediatr Nurs. 1998;13(3):175-84. 
Cejer B. The needs and experiences of long term ventilated children and their families. Paediatr Nurs. 2007;19(5):42-5.

Cunha I, Cabral IE. A enfermagem e as condições de vida da criança dependente de tecnologia: um desafio para o ato educativo problematizador. Rev Soc Bras Enfermeir Pediatr. 2001;1(1):71-9.

Cunha SR. A enfermeira e a família da criança dependente de tecnologia: a intermediação dos saberes [dissertação]. Rio de Janeiro: Escola de Enfermagem Anna Nery, Universidade Federal do Rio de Janeiro; 1997.

Drucker LP. Rede de suporte tecnológico domiciliar à criança dependente de tecnologia egressa de um hospital de saúde pública. Cienc Saúde Coletiva. 2007;12(5):1285-94.

Edwards EA, O'Toole M, Wallis C. Sending children home on tracheostomy dependent ventilation: pitfalls and outcomes. Arch Dis Child. 2004;89(3):2515.

Fundo das Nações Unidas para a Infância (UNICEF). Situação mundial da infância 2003: participação infantil [texto na internet]. Brasília; 2002a [citado 2006 dez. 19]. Disponível em: http://www.unicef.org/brazil/sowc03/.

Fundo das Nações Unidas para a Infância (UNICEF). Situação da infância brasileira 2001. Desenvolvimento infantil: os seis primeiros anos de vida [texto na internet]. Brasília; 2001b [citado 2006 dez. 19]. Disponível em: http://www.unicef.org/brazil/sib2001/index.htm.

Gil AC. Como elaborar projetos de pesquisa. 3a ed. São Paulo: Atlas; 1991.

Gílio AE, Terra CM. Ventilação pulmonar mecânica no domicílio. In: Carvalho BC, Freddi NA, Hirschheimer MR, Proença JO, Ribeiro R. Ventilação pulmonar mecânica em pediatria. São Paulo: Atheneu; 1993. p. 353-6.

Glendinning C, Kirk S, Guiffrida A, Lawton D. Technology-dependent children in the community: definitions, numbers and costs. Child Care Health Dev. 2001;27(4):321-34.

Gowans M, Keenan $\mathrm{H}$, Bratton S. The population prevalence of children receiving invasive home ventilation in Utah. Pediatr Pulmonol. 2007;42(3):231-6. 
Grupo de Pesquisa "Cuidado à Saúde Infantil" [homepage na internet]. São Paulo; c2000 [atualizado 27 nov. 2006; citado 2008 mar. 20]. Disponível em: http://dgp.cnpq.br/buscaoperacional/detalhegrupo.jsp?grupo=0067404JCDM VY2.

Hockenberry $\mathrm{MJ}$, Winkelstein $\mathrm{W}$. Wong: fundamentos de enfermagem pediátrica. $7^{\mathrm{a}}$ ed. Rio de Janeiro: Elsevier; 2006. Influências do desenvolvimento na promoção da saúde da criança; p. 79-103.

Jardine $\mathrm{E}$, O'Toole $\mathrm{M}$, Paton $\mathrm{J}$, Wallis C. Current status of long term ventilation of children in the United Kingdom: questionnaire survey. BMJ. 1999;318(7179):295-9.

Lima EC, Issi HB, Cachafeiro MEH, Hillig MG, Ribeiro NRR. Modelo de cuidado diferenciado de enfermagem à família da criança internada na unidade de terapia intensiva pediátrica. Fam Saúde Desenv. 2006;168-77.

Mattos RA. Os sentidos da integralidade: algumas reflexões acerca de valores que merecem ser definidos [texto na internet]. Rio de Janeiro: LAPPIS; [200-] [citado 2006 dez. 21]. Disponível em: http://www.lappis.org.br/cgi/cgilua.exe/sys/start.htsid=25\&infoid=80\&tpl=view_partici pantes

Maslow AH. Motivation and personality. $2^{\mathrm{a}}$ ed. New York: Harper \& Row;1970.

Minayo MCS. O desafio do conhecimento: pesquisa qualitativa em saúde. $6^{a}$ ed. São Paulo: Hucitec/ABRASCO; 1999.

Noyes J. 'Ventilator-dependent' children who spend prolonged periods of time in intensive care units when they no longer have a medical need or want to be there. J Clin Nurs. 2000a;9(5):774-83.

Noyes J. Enabling young ventilator-dependent people to express their views and experiences of their care in hospital. J Adv Nurs. 2000b;31(5):1206-15.

Noyes J. The experiences and views of parents who care for ventilatordependent children. J Clin Nurs. 1999;8: 440-50.

O'Brien ME, Wegner CB. Rearing the child who is technology dependent: perceptions of parents and home care nurses. JSPN. 2002;7(1):7-15.

Organização Pan-Americana da Saúde (OPAS). Promoção do crescimento e 
desenvolvimento integral de crianças e adolescentes: módulos de aprendizagem. Washington (DC); 1999. (OPAS-Publicação Científica, série HCT/AIEPI-25.P.1).

Petersen DJ, Alexander GR. Needs assessment in public health: A practical guide for students and professionals. New York: Kluwer Academic; 2001.

Piccolo J, Takahashi M, Peterline MAS, Pedreira MLG. Manual de orientação para pais de crianças traqueostomizadas [CD-ROM]. In: Anais do $8^{\circ}$ Enftec: Enfermagem no Século XXI - Reflexões e Visões; 2002; São Paulo, SP, BR. São Paulo: Sonopress; 2002.

Rezende, MA. Alimentação infantil e o cuidado de enfermagem [livredocência]. São Paulo: Escola de Enfermagem, Universidade de São Paulo; 2008.

Sekkel MC. Reflexões sobre possibilidades e limites da educação inclusiva. Boletim Psicol. 2005;LV (122): 43-58.

Sherman JM, Davis S, Albamonte-Petrick S, Chatburn RL, Fitton C, Green C et al. Care of the child with a chronic tracheostomy. Am J Respir Crit Care Med. 2000;161(1):297-308.

Shore R. Repensando o cérebro. Porto Alegre: Mercado Aberto; 2000.

Siebert R. O adulto frente à criança: ao mesmo tempo igual e diferente. In: Bondioli A, Mantovani S. Manual de educação infantil. $9^{\mathrm{a}}$ ed. Porto Alegre: Artmed; 1998. p. 77-87.

Sigaud CHS, Veríssimo MLOR, organizadores. Enfermagem pediátrica: o cuidado de enfermagem à criança e ao adolescente. São Paulo: EPU; 1996. O ser criança; p. 11-4.

Silva SSC, Le Pendu Y, Pontes FAR. Sensibilidade materna durante 0 banho. Psic Teor Pesq. 2002;18(3):345-52.

Spitz R. O primeiro ano de vida. São Paulo: Martins Fontes; 1983. Distúrbios psicotóxicos; p. 189-232.

Spósito MMM. Estimulação do paciente sob ventilação pulmonar mecânica. In: Carvalho BC, Freddi NA, Hirschheimer MR, Proença JO, Ribeiro R. Ventilação pulmonar mecânica em pediatria. São Paulo: Atheneu; 1993. p. 383-92. 
Tanaka I, Imperial MCG. Histórico da ventilação pulmonar mecânica. In: Carvalho BC, Freddi NA, Hirschheimer MR, Proença JO, Ribeiro R. Ventilação pulmonar mecânica em pediatria. São Paulo: Atheneu; 1993. p. 19.

United States Congress. Office of Technology Assessment. Technologydependent children: hospital vs. home care. A technical memorandum, OTATM-H_38. Washington (DC): US Government Printing Office; 1987.

Veríssimo MLOR, Rezende MA. O cuidado da criança na creche e préescola. In: Santos LES. Creche e pré-escola: uma abordagem de saúde. São Paulo: Artes Médicas; 2004. p. 55-61.

Veríssimo MLOR, Sigaud CHS, Rezende MA, Ribeiro MO. O cuidado e as necessidades de saúde da criança. In: Fujimori E, Silva CV. Enfermagem e a saúde da criança na atenção básica. São Paulo: Manole. Cap. 7. No prelo.

Wong DL, Whaley LF. Enfermagem pediátrica: elementos essenciais à intervenção efetiva. $5^{a}$ ed. Rio de Janeiro: Guanabara Koogan; 1999a. Influências do desenvolvimento na promoção da saúde da criança; p. 73-92.

Wong DL, Whaley LF. Enfermagem pediátrica: elementos essenciais à intervenção efetiva. 5a ed. Rio de Janeiro: Guanabara Koogan; 1999b. Cuidado domiciliar centrado na família; p. 532- 41.

Wong DL, Whaley LF. Enfermagem pediátrica: elementos essenciais à intervenção efetiva. 5a ed. Rio de Janeiro: Guanabara Koogan; 1999c. Promoção da saúde do recém-nascido e da família; p. 157-94. 


\section{ANEXO 01}

\section{Códigos e referências dos artigos que compuseram o corpus de}

análise.

\begin{tabular}{|c|c|}
\hline \multicolumn{2}{|c|}{ Processo de transição do hospital para casa/comunidade } \\
\hline Código & Referência \\
\hline C76 & $\begin{array}{l}\text { "How we managed" series. Amanda comes home -- on 24-hour ventilatory care. Prof } \\
\text { Care Mother Child. 2000;10(4):92-3. }\end{array}$ \\
\hline C71 & $\begin{array}{l}\text { Boosfeld B, O'Toole M. Technology-dependent children: transition from hospital to } \\
\text { home. Paediatr Nurs. 2000;12(6):20-2. }\end{array}$ \\
\hline P204 & $\begin{array}{l}\text { Capen C, Dedlow E. Discharging ventilator-dependent children: a continuing } \\
\text { challenge. J Pediatr Nurs. 1998;13(3):175-84. }\end{array}$ \\
\hline C77 & $\begin{array}{l}\text { Cohen } \mathrm{MH} \text {. The technology-dependent child and the socially marginalized family: a } \\
\text { provisional framework. Qual Health Res. } 1999 ; 9(5): 654-68 \text {. }\end{array}$ \\
\hline P103 & $\begin{array}{l}\text { Edwards EA, O'Toole M, Wallis C. Sending children home on tracheostomy dependent } \\
\text { ventilation: pitfalls and outcomes. Arch Dis Child. 2004;89(3):251-5. }\end{array}$ \\
\hline P29 & $\begin{array}{l}\text { Jardine E, Wallis C. Core guidelines for the discharge home of the child on long-term } \\
\text { assisted ventilation in the United Kingdom. UK Working Party on Paediatric Long Term } \\
\text { Ventilation. Thorax. 1998;53(9):762-7. }\end{array}$ \\
\hline P78 & $\begin{array}{l}\text { Leurer M, Be'eri E, Zilbershtein D. Discharge of respiratory-compromised children after } \\
\text { respiratory rehabilitation. Isr Med Assoc J. 2006;8(7):473-6. }\end{array}$ \\
\hline C72 & $\begin{array}{l}\text { Nelson VS, Lewis CC. Ventilatory support: preparing for discharge... The Howard H. } \\
\text { Steel Conference on Pediatric Spinal Cord Injury, Rancho Mirage, California, } \\
\text { December 3-5, 1999. Top Spinal Cord Inj Rehabil. 2000;6:16-24. }\end{array}$ \\
\hline P36 & $\begin{array}{l}\text { Noyes J. Barriers that delay children and young people who are dependent on } \\
\text { mechanical ventilators from being discharged from hospital. J Clin Nurs. 2002;11(1):2- } \\
11 \text {. }\end{array}$ \\
\hline C67 & $\begin{array}{l}\text { Noyes J. 'Ventilator-dependent' children who spend prolonged periods of time in } \\
\text { intensive care units when they no longer have a medical need or want to be there. J } \\
\text { Clin Nurs. 2000;9(5):774-83. }\end{array}$ \\
\hline C24 & $\begin{array}{l}\text { Ringler RD. Bringing home baby... and her vent, too. Nurs Spectr - (N Jersey Ed). } \\
2005 ; 17 A(2): 14-5 .\end{array}$ \\
\hline P24 & $\begin{array}{l}\text { Storgion S, Stutts A. Transitional care: a multidisciplinary case management-based } \\
\text { unit. Pediatr Nurs. 2000;26(6):564-8. }\end{array}$ \\
\hline P58 & $\begin{array}{l}\text { Tearl D, Cox T, Hertzog J. Hospital discharge of respiratory-technology-dependent } \\
\text { children: role of a dedicated respiratory care discharge coordinator. Respir Care. } \\
2006 ; 51(7): 744-9 \text {. }\end{array}$ \\
\hline P17 & $\begin{array}{l}\text { Tearl D, Hertzog J. Home discharge of technology-dependent children: evaluation of a } \\
\text { respiratory-therapist driven family education program. Respir Care. 2007;52(2):171-6. }\end{array}$ \\
\hline
\end{tabular}




\begin{tabular}{|c|c|}
\hline \\
\hline \multicolumn{2}{|c|}{$\begin{array}{l}\text { Interação criança-cuidador } \\
\text { Código } \quad \text { Referência }\end{array}$} \\
\hline P34 & $\begin{array}{l}\text { Hewitt-Taylor J. Children who require long-term ventilation: staff education and } \\
\text { training. Intensive Crit Care Nurs. } 2004 ; 20(2): 93-102 \text {. }\end{array}$ \\
\hline P20 & $\begin{array}{l}\text { Kuster P, Badr L. Mental health of mothers caring for ventilator-assisted children at } \\
\text { home. Issues Ment Health Nurs. } 2006 ; 27(8): 817-35 \text {. }\end{array}$ \\
\hline P98 & $\begin{array}{l}\text { Kuster P, Badr L, Chang B, Wuerker A, Benjamin A. Factors influencing health } \\
\text { promoting activities of mothers caring for ventilator-assisted children. J Pediatr Nurs. } \\
2004 ; 19(4): 276-87 \text {. }\end{array}$ \\
\hline P19 & $\begin{array}{l}\text { Meltzer L, Mindell J. Impact of a child's chronic illness on maternal sleep and daytime } \\
\text { functioning. Arch Intern Med. 2006;166(16):1749-55. }\end{array}$ \\
\hline C57 & Meservey RL, Jr. A day with Kevin. Nursing. 2001;31(7):32hn5-hn5. \\
\hline C56 & Sanders R. Caring for ventilated children at home. Nurs Times. 2001;97(39):42-3. \\
\hline P18 & $\begin{array}{l}\text { Wilson S, Morse J, Penrod J. Developing reciprocal trust in the caregiving relationship. } \\
\text { Qual Health Res. 1998;8(4):446-65. }\end{array}$ \\
\hline
\end{tabular}

\begin{tabular}{|c|c|}
\hline \multicolumn{2}{|c|}{ Experiência da criança e da família } \\
\hline Código & Referência \\
\hline P115 & $\begin{array}{l}\text { Alexander E, Rennick J, Carnevale F, Davis M. Daily struggles: living with long-term } \\
\text { childhood technology dependence. Can J Nurs Res. 2002;34(4):7-14. }\end{array}$ \\
\hline P21 & $\begin{array}{l}\text { Carnevale F, Alexander E, Davis M, Rennick J, Troini R. Daily living with distress and } \\
\text { enrichment: the moral experience of families with ventilator-assisted children at home. } \\
\text { Pediatrics. } 2006 ; 117(1): \text { e } 48-60 \text {. }\end{array}$ \\
\hline $\mathrm{C} 42$ & $\begin{array}{l}\text { Colville GA, Mok Q. Psychological management of two cases of self injury on the } \\
\text { paediatric intensive care unit. Arch Dis Child. 2003; 88(4):335-6. }\end{array}$ \\
\hline P76 & $\begin{array}{l}\text { Earle R, Rennick J, Carnevale F, Davis G. 'It's okay, it helps me to breathe': the } \\
\text { experience of home ventilation from a child's perspective. J Child Health Care. } \\
2006 ; 10(4): 270-82 \text {. }\end{array}$ \\
\hline P1 & $\begin{array}{l}\text { Levine C. Acceptance, avoidance, and ambiguity: conflicting social values about } \\
\text { childhood disability. Kennedy Inst Ethics J. 2005;15(4):371-83. }\end{array}$ \\
\hline P13 & $\begin{array}{l}\text { Margolan H, Fraser J, Lenton S. Parental experience of services when their child } \\
\text { requires long-term ventilation. Implications for commissioning and providing services. } \\
\text { Child Care Health Dev. 2004;30(3):257-64. }\end{array}$ \\
\hline P146 & $\begin{array}{l}\text { Noyes J. Enabling young 'ventilator-dependent' people to express their views and } \\
\text { experiences of their care in hospital. J Adv Nurs. } 2000 ; 31(5): 1206-15 \text {. }\end{array}$ \\
\hline
\end{tabular}




\begin{tabular}{|l|l|}
\hline P28 & $\begin{array}{l}\text { Noyes J, Hartmann H, Samuels M, Southall D. The experiences and views of parents } \\
\text { who care for ventilator-dependent children. J Clin Nurs. 1999; 8(4):440-50. }\end{array}$ \\
\hline C90 & $\begin{array}{l}\text { Wilson S, Morse JM, Penrod J. Absolute involvement: the experience of mothers of } \\
\text { ventilator-dependent children. Health Soc Care Community. 1998;6(4):224-33. }\end{array}$ \\
\hline
\end{tabular}

\begin{tabular}{|l|l|}
\hline \multicolumn{2}{|l|}{ Proteção e segurança } \\
\hline Código & Referência \\
\hline P207 & $\begin{array}{l}\text { Ambrosio I, Woo M, Jansen M, Keens T. Safety of hospitalized ventilator-dependent } \\
\text { children outside of the intensive care unit. Pediatrics. 1998; 101(2):257-9. }\end{array}$ \\
\hline
\end{tabular}

\begin{tabular}{|l|l|}
\hline \multicolumn{2}{|l|}{ Artigos de revisão } \\
\hline Código & Referência \\
\hline P59 & $\begin{array}{l}\text { Amin R, Fitton C. Tracheostomy and home ventilation in children. Semin Neonatol. } \\
2003 ; 8(2): 127-35 .\end{array}$ \\
\hline P16 & $\begin{array}{l}\text { Haffner J, Schurman S. The technology-dependent child. Pediatr Clin North Am. } \\
2001 ; 48(3): 751-64 .\end{array}$ \\
\hline P62 & $\begin{array}{l}\text { Hammer J. Home mechanical ventilation in children: indications and practical aspects. } \\
\text { Schweiz Med Wochenschr. 2000;130(49):1894-902. }\end{array}$ \\
\hline
\end{tabular}

\begin{tabular}{|l|l|}
\hline \multicolumn{2}{|l|}{ Qualidade de vida } \\
\hline Código & Referência \\
\hline P27 & $\begin{array}{l}\text { Lumeng J, Warschausky S, Nelson V, Augenstein K. The quality of life of ventilator- } \\
\text { assisted children. Pediatr Rehabil. 2001;4(1):21-7. }\end{array}$ \\
\hline
\end{tabular}




\section{Anexo 02}

INSTRUMENTO DE ANÁLISE DOS DOCUMENTOS

Código do documento:

ANÁLISE TEXTUAL

01 - Dados de identificação do documento

\begin{tabular}{|l|l|}
\hline Título & \\
\hline Autor/es & \\
\hline Ano & \\
\hline Fonte & \\
\hline Local & \\
\hline Database & \\
\hline Palavra-chave & \\
\hline Referência & \\
\hline
\end{tabular}

02 - Informações sobre o/os autor/autores

\begin{tabular}{|l|}
\hline \\
\hline \\
\hline \\
\hline
\end{tabular}

03 - Esquematização do documento

\section{Temática}

Tipo de estudo

Objetivo

Ambiente da pesquisa

Localização geográfica 
04 - Informações sobre os participantes

\section{Tipo de participante}

Vínculo estabelecido com a criança dependente de ventilador

05 - Caracterização da criança (população alvo do estudo)

\begin{tabular}{|l|l|}
\hline Idade da criança & \\
\hline Causa (uso do ventilador) & \\
\hline Tipo e duração da ventilação & \\
\hline Fatores biológicos associados & \\
\hline Idade de início da dependência & \\
\hline $\begin{array}{l}\text { Tipo de assistência predominante } \\
\text { (domiciliar/hospitalar) }\end{array}$ & \\
\hline Cuidador habitual & \\
\hline $\begin{array}{l}\text { Vínculo à um grupo social } \\
\text { específico }\end{array}$ \\
\hline
\end{tabular}

06 - Resumo do documento 


\section{ANÁLISE TEMÁTICA}

01 - Transcrição de trechos referentes ao desenvolvimento infantil.

\begin{tabular}{|l|l|l|}
\hline Introdução & Página__ & Trecho__ Tema \\
\hline & \\
\hline & \\
\hline & \\
\hline & \\
\hline & \\
\hline & \\
\hline & \\
\hline
\end{tabular}

\begin{tabular}{|l|l|l|}
\hline Desenvolvimento & Página___ Trecho__ & Tema \\
\hline & \\
\hline & \\
\hline & \\
\hline & \\
\hline & \\
\hline & \\
\hline
\end{tabular}

\begin{tabular}{|c|c|c|}
\hline Conclusão & \begin{tabular}{|l|l|} 
Página & Trecho \\
\end{tabular} & Tema \\
\hline & & \\
\hline & & \\
\hline & & \\
\hline & & \\
\hline & & \\
\hline & & \\
\hline
\end{tabular}

